\title{
Multimedia Contaminant Environmental Exposure Assessment Methodology as Applied to Los Alamos, New Mexico
}
G. Whelan
F. L. Thompson
S. B. Yabusaki

February 1983

Prepared for the Los Alamos National Laboratory under a Related Services Agreement with U.S. Department of Energy Contract DE-AC06-76RLO 1830

Pacific Northwest Laboratory Operated for the U.S. Department of Energy by Battelle Memorial Institute 


\title{
DISCLAIMER
}

This report was prepared as an account of work sponsored by an agency of the United States Government. Neither the United States Government nor any agency thereof, nor any of their employees, makes any warranty, express or implied, or assumes any legal liability or responsibility for the accuracy, completeness, or usefulness of any information, apparatus, product, or process disclosed, or represents that its use would not infringe privately owned rights. Reference herein to any specific commercial product, process, or service by trade name, trademark, manufacturer, or otherwise, does not necessarily constitute or imply its endorsement, recommendation, or favoring by the United States Government or any agency thereof. The views and opinions of authors expressed herein do not necessarily state or reflect those of the United States Government or any agency thereof.

\author{
PACIFIC NORTHWEST LABORATORY \\ operated by \\ BATTELLE \\ for the \\ UNITED STATES DEPARTMENT OF ENERGY \\ under Contract DE-AC06-76RLO 1830
}

\begin{tabular}{|c|c|}
\hline \multicolumn{2}{|c|}{$\begin{array}{l}\text { Printed in the United States of America } \\
\text { Available from } \\
\text { National Technical Information Service } \\
\text { United States Department of Commerce } \\
5285 \text { Port Royal Road } \\
\text { Springfield, Virginia } 22161\end{array}$} \\
\hline \multicolumn{2}{|c|}{$\begin{array}{l}\text { NTIS Price Codes } \\
\text { Microfiche A01 }\end{array}$} \\
\hline \multicolumn{2}{|c|}{ Printed Copy } \\
\hline Pages & $\begin{array}{l}\text { Price } \\
\text { Codes }\end{array}$ \\
\hline $001-025$ & $\mathrm{~A} 02$ \\
\hline $026-050$ & $\mathrm{~A} 03$ \\
\hline $051-075$ & $\mathrm{~A} 04$ \\
\hline $076-100$ & A05 \\
\hline $107-125$ & A06 \\
\hline $126-150$ & $\mathrm{~A} 07$ \\
\hline $157-175$ & $\mathrm{~A} 08$ \\
\hline $176-200$ & $A 09$ \\
\hline $201-225$ & A010 \\
\hline $226-250$ & A011 \\
\hline $251-275$ & $\mathrm{~A} 012$ \\
\hline $276-300$ & $\mathrm{~A} 013$ \\
\hline
\end{tabular}


MULTIMEDIA CONTAMINANT ENVIRONMENTAL EXPOSURE ASSESSMENT METHODOLOGY AS APPLIED TO LOS ALAMOS, NEW MEXICO

G. Whelan

F. L. Thompson

S. B. Yabusaki

February 1983

Prepared for the

Los Alamos National Laboratory

Los Alamos, New Mexico

under a Related Services Agreement with

U.S. Department of Energy

Contract DE-AC06-76RLO 1830

Pacific Northwest Laboratory

Richland, Washington 99352 


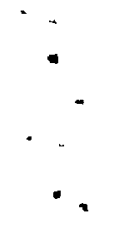




\section{ACKNOWLEDGMENTS}

The authors would like to extend their appreciation to Mr. John Rodgers of the Los Alamos National Laboratory for his assistance and technical support in the comprehensive multimedia radionuclide exposure assessment methodology and Dr. Yasuo Onishi of the Pacific Northwest Laboratory for nis constructive technical comments. Special thanks are extended to the Los Alamos National Laboratory in providing funding for this project under a related services agreement with the U.S. Department of Energy, Contract DE-AC06-76RLO 1830. 


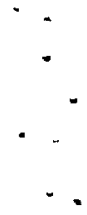




\section{EXECUTIVE SUMMARY}

Pacific Northwest Laboratory (PNL) used a methodology for predicting the migration and fate of radionuclides in the environment to assess ${ }^{239} \mathrm{Pu}$ migration in the vicinity of Los Alamos National Laboratory (LANL). The MCEA (Multimedia Contaminant Environmental Exposure Assessment) methodology, which was jointly developed by PNL and LANL, assesses exposures to air, water, soil, and plants from contaminants released into the environment by simulating dominant mechanisms of contaminant migration and fate. The metnodology is more sophisticated than those for a basic worst-case scenario analysis, but less sophisticated than a full-scaled, extremely detailed, expensive and timeconsuining onsite survey. The methodology encompasses five different pathways (i.e., atmospheric, terrestrial, overland, subsurface, and surface water) and combines them into a highly flexible tool. The flexibility of the MCEA methodology is demonstrated in this study by encompassing two of the pathways (i.e., overland and surface water) into an effective tool for simulating the migration and fate of radionuclides released into the Los Alamos, New Mexico region.

The purpose of this study was to assess the potential migration and fate of radionuclides in Los $A$ lamos and Pueblo Canyons. Specifically, a precipitation-generated flood event with a recurrence interval of $50 \mathrm{yr}$ was simulated in Los Alamos and Pueblo Canyons to simulate the degree to which radionuclides would migrate into lower Los Alamos Canyon. PNL performed this work in cooperation with LANL.

The MCEA methodology was employed to simulate the resuspension, deposition, sorption, migration, and fate of $239 \mathrm{Pu}$ adsorbed onto bed sediments. The scenario studied nerein assumed the ${ }^{239} \mathrm{pu}$ concentrations currently existing at the modeling site as the initial conditions. A temporally varying, spatially uniform precipitation event representing a possible 50-yr flood event was used in the modeling scenario. The 50-yr event was chosen in an attempt to simulate a critical event (i.e., one which may transport significant amounts of $239 \mathrm{Pu}$ downstream and deposit them into lower 
Los Alamos Canyon). Uverland runoff events transported water and sediment to the channel's edge as lateral inflow. The movement of water and sediment along with contaminated bed sediment entrained into the flow were simulated for the precipitation-generated flood event.

The study revealed that a) the ${ }^{239} \mathrm{Pu}$ inventory in lower Los Alamos Canyon increased by approximately 1.1 times for the 50-yr flood event; b) the average contaminant ${ }^{239} \mathrm{Pu}$ concentrations (i.e., weighted according to the depth of the respective bed layer) in lower Los Alamos Canyon for the 50-yr flood event decreased by $5.4 \%$; c) $\sim 27 \%$ of the total $239 \mathrm{Pu}$ contaminaton resuspended from the entire bed (based on the assumed cross sections) for the 50-yr flood event originated from lower Pueblo Canyon; d) an increase in the $239 \mathrm{pu}$ contaminaton of the bed followed the general deposition patterns experienced by the sediment in Pueblo-lower Los Alamos Canyon; likewise, a decrease in the ${ }^{239} \mathrm{Pu}$ contamination of the bed followed general sediment resuspension patterns in the canyon; e) $55 \%$ of the ${ }^{239} \mathrm{Pu}$ reaching the San 11 defonso Pueblo in lower Los Alamos Canyon originated from lower Los Alamos Canyon; and f) $56 \%$ of the ${ }^{239} \mathrm{Pu}$ contamination reaching the San Ildefonso Pueblo in lower Los Alamos Canyon was carried through towards the Rio Grande. 


\section{CONTENTS}

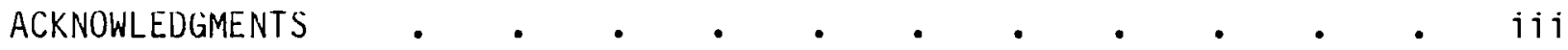

EXECUTIVE SUMMARY

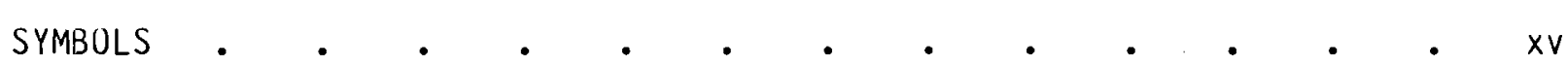

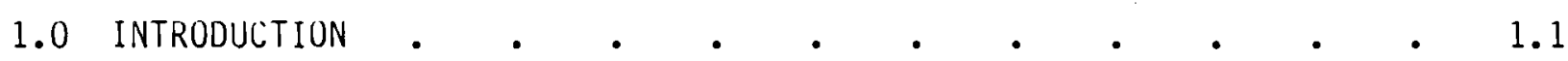

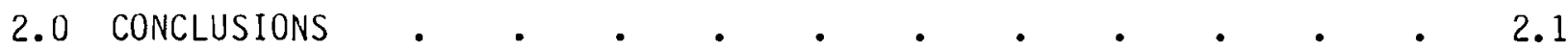

3.0 MULTIMEDIA CONTAMINANT ENVIRONMENTAL EXPOSURE ASSESSMENT

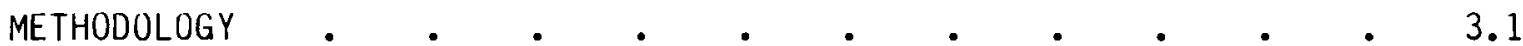

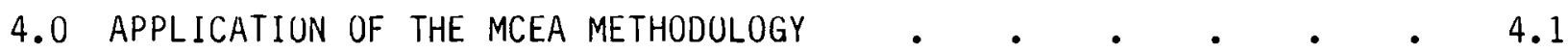

4.1 LOGISTICS OF APPLYING THE METHODOLOGY • • • • • • • 4.1

4.1.1 Formerly Utilized Sites Remedial Action Program . $\quad 4.1$

4.1.2 Los Alamos and Pueblo Canyons . . . . . . $\quad$. 4.6

4.1.3 Pathway and Model Selection . . . . . . . 4.28

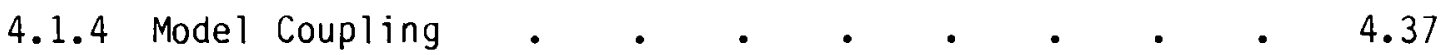

4.1.5 Precipitation and Flood Event Scenarios . . . 4.39

4.2 UVERLAND SEDIMENT-CONTAMINANT TRANSPORT MUDELING $\quad$ • $\quad$ • $\quad 4.48$

4.2.1 Introduction $. \quad . \quad . \quad . \quad . \quad . \quad . \quad . \quad . \quad .484$

4.2.2 Numerical Modeling Representation. • • • • • 4.48

4.2.3 Model Calibration and Results . $\quad$. $\quad . \quad$. 4.51

4.2.4 Model Application and Results . $\quad$. $\quad . \quad$. 4.64

4.3 IN-STREAM HYORODYNAMIC MODELING $\quad$ • $\quad$ • $\quad$ • 4.67

4.3 .1 Introduction . $. \quad . \quad . \quad . \quad . \quad . \quad 4.67$

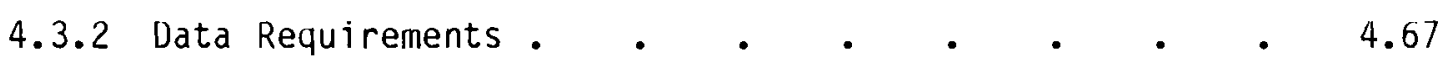

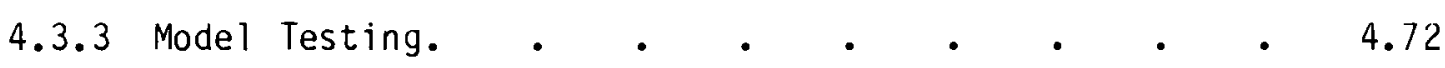

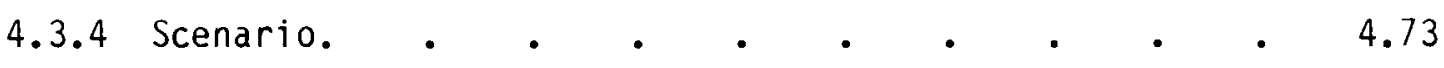




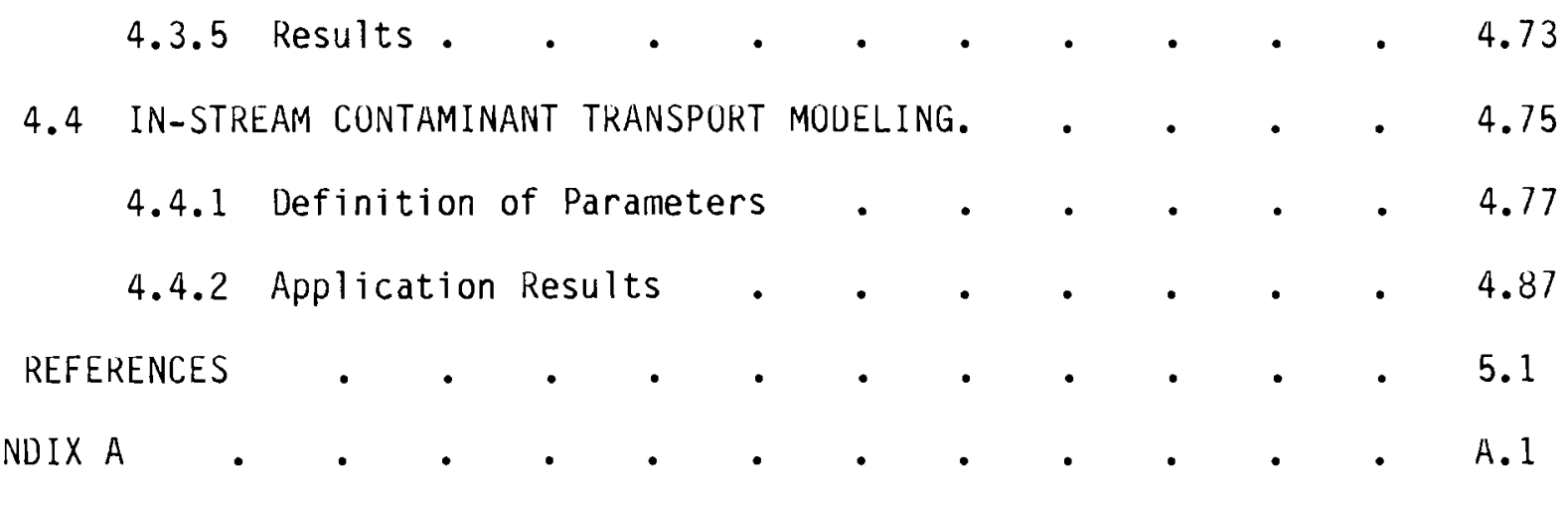




\section{FIGURES}

3.1 Schematic Diagram Illustrating the Interactions Between the Various Transporting Media and How They Affect Man Through His Environment $. \quad . \quad . \quad . \quad . \quad . \quad . \quad . \quad . \quad . \quad 3.3$

4.1 Topography of the Los Alamos Area in New Mexico $\quad$ • $\quad$ • 4.2

4.2 Acid-Pueblo and DP-Los Alamos Canyons . . . . . 4.3

4.3 Land Uwnership or Management in Study Area.$\quad$. $\quad$. 4.4

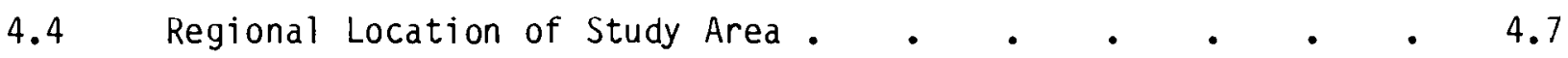

4.5 Monitoring Net in Acid-Puebio DP-Los Alamos Canyons, 1949-1975. . . . . . . . . . . . . 4.11

4.6 Sediment-Size Distribution of Channel Sediments from

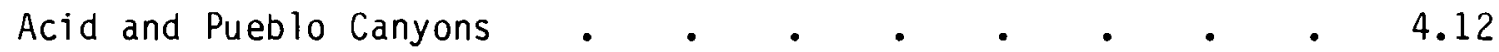

4.7 Sediment-Size Distribution of Channel Sediments from

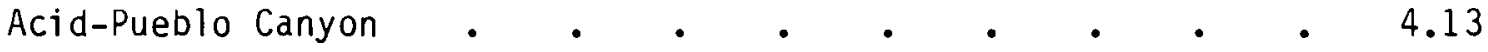

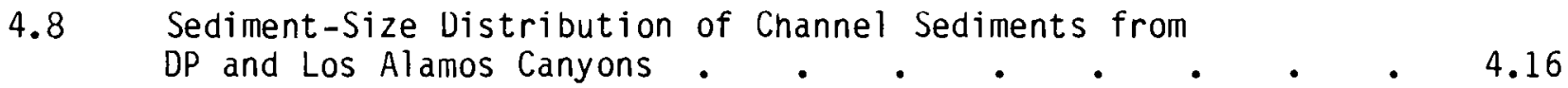

4.9 Sediment-Size Distributions of Channel Sediments from

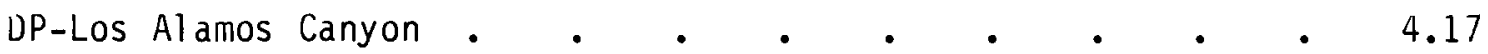

4.10 Average Sediment-Size Distribution of Weather Tuff and Channel and Suspended Sediments in DP Canyon . .4 .18

4.11 Concentration of ${ }^{239} \mathrm{Pu}$ on Soils and Sedinents by

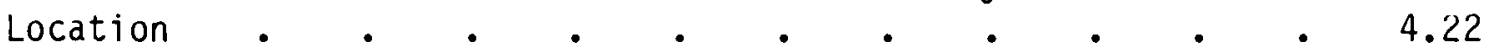

4.12 Estimated Inventory of ${ }^{239} \mathrm{Pu}$ on Soils and Sediments by

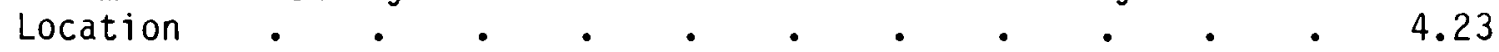

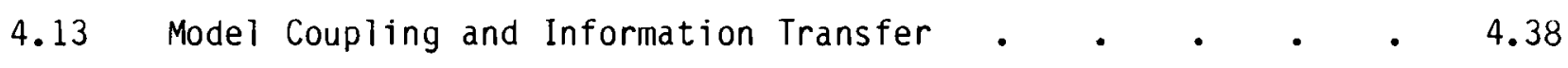

4.14 Los Alamos Precipitation Frequency Estimates from the National Weather Service NOAA Atlas-2 . . . . . 4.42

4.15 Los Alamos Maximum 24-Hour Precipitation Frequency . . . 4.43

4.16 Relation Between Ubserved and Estimated Maximum 24-Hour Precipitation Amounts at Los Alamos for Return Periods of 2 to 100 Years 
4.17 Peak Discharge Versus Recurrence Intervals for Five

Catchments in and Around the Los Alamos Area . . . . 4.47

4.18 Subdivision of the Study Area for Application of ARM • $\quad 4.49$

4.19 Simulated Runoff for the Storm of $7 / 14 / 76$. $\quad$ • $\quad$. 4.60

4.20 Simulated Runoff for the Storm of $7 / 16 / 76$. 4.60

4.21 Simulated Runoff for the Storm of $8 / 1 / 76$. $\quad$ • $\quad$ • $\quad$ e 4.61

4.22 Simulated Runoff for the Storm of $8 / 11 / 76$. . . . . 4.61

4.23 Comparison of Simulated and Observed Suspended Sediment
Concentrations in DP Canyon
C

4.24 Segments Used for Application of MODSEEP and TODAM • • • 4.68

4.25 Head of Acid Canyon - 50-Year Flood Event . . . . • . 4.74

4.26 Confluence of Pueblo-Los Alamos Canyon - 50-Year Flood

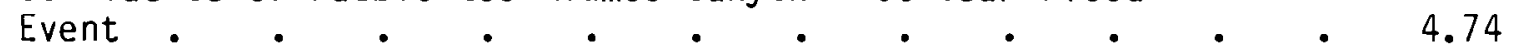

4.27 Lower Los Alamos Canyon - 50-Year Flood Event . • • 4.75

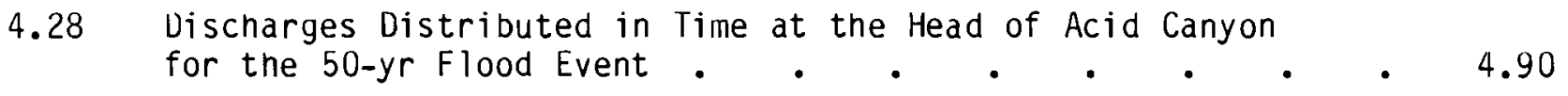

4.29 Discharges vistributed in Time at the Confluence of

4.30 Discharges Vistributed in Time at Lower Los Alamos
Canyon for the 50-yr Flood Event

4.31 Sediment Flow Rates Distributed in Time at the Head
of Acid Canyon for the 50-yr Flood Event . $~ • ~$

4.32 Sediment Flow Rates Distributed in Time at the Confluence of
Pueblo-Los Alamos Canyon for the 50-yr Flood Event • • $\quad 4.92$

4.33 Sediment Flow Rates Distributed in Time at Lower Los Alamos

4.34 Simulated Net Weight of Sediment Deposited/Resuspended

to/from the Channel Bed for the 50-yr Flood Event . . . 4.94

4.35 Plutonium-239 Flow Rates vistributed in Time at the Confluence

of Puebio-Los Alamos Canyon for the 50-yr Flood Event . 4.97

4.36 Plutoniuim-239 Flow Rates Distributed in Time at Lower
Los Alamos Canyon for the 50-yr Flood Event.$\quad$ • 
4.37 Particulate ${ }^{239} \mathrm{Pu}$ Flow Rates Distributed in Time at the Confluence of Pueblo-Los Alamos Canyon for the 50-yr Flood Event.

4.38 Particulate ${ }^{239}$ Pu Flow Rates Distributed in Time at Lower Los Alamos Canyon for the 50-yr Flood Event . . . 4.99

4.39 Particulate ${ }^{239} \mathrm{Pu}$ Concentrations in $\mathrm{pCi} / \mathrm{kg}$ Distributed in Time at the Confluence of Pueblo-Los Alamos Canyon for the 50-yr Flood Event $. \quad . \quad . \quad . \quad . \quad . \quad . \quad . \quad 4.101$

4.40 Particulate $239 \mathrm{Pu}$ Concentrations in $\mathrm{pCi} / \mathrm{kg}$ vistributed in Time at Lower Los Alamos Canyon for the 50-yr Flood Event • 4.101 


\section{$\underline{\text { TABLES }}$}

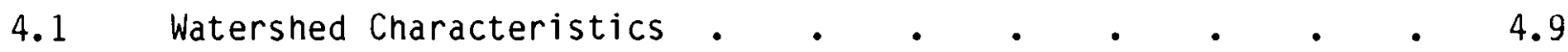

4.2 Particle-Size Distribution of Channel Sediments from
Acid-Pueblo Canyon . . . . . . . . . . 4.10

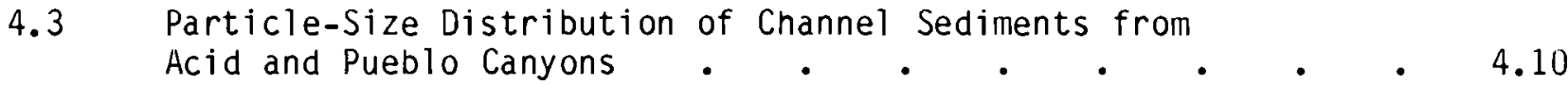

4.4 Particle-Size Distribution of Channel Sediments from

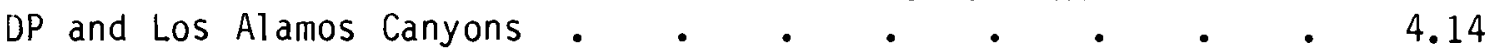

4.5 Particle-Size Distribution of Channel Sediments from OP-Los Alamos Canyon $. \quad . \quad . \quad . \quad . \quad . \quad . \quad . \quad . \quad 4.14$

4.6 Average Particle-Size Distribution of Weathered Tuff and Channel and Suspended Sediments in DP Canyon . .4 .14

4.7 Measured Bed Contanination Levels of ${ }^{239} \mathrm{Pu}$ in Acid, Pueblo, and Lower Los Alamos Canyons . . . . . . 4.15

4.8 Measured Bed Contamination Levels of ${ }^{239} \mathrm{Pu}$ in Upper

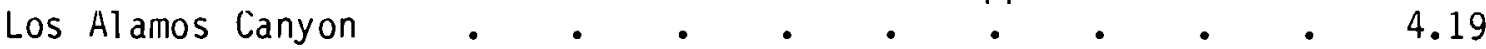

4.9 Measured Bed Contamination Levels of ${ }^{239} \mathrm{Pu}$ in Acid

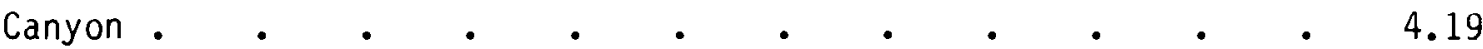

4.10 Plutonium in Sediments from Acid-Pueblo Canyon Special

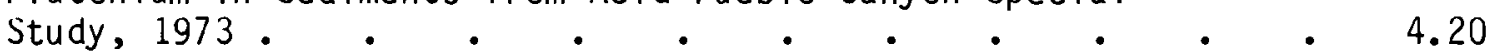

4.11 Plutonium in Sediments from UP-Los Alamos Canyon Special Study, 1973 .

4.12 Watershed Size, Flood Frequency, and Corresponding Maximum Discharge for Bayo, Acid-Pueblo, and DP-Upper Los Alamos Canyons

4.13 Precipitation Frequency Estimates for Los Alamos, NM $\quad$ • $\quad$ • 4.41

4.14 Flood Frequency and Maximum Discharge for Acid-Pueblo and UP-Los Alamos Canyons . . . . . . . . 4.45

4.15 Supplementary Information Related to the Curves in Figure 4.17 .

4.16 Watershed Characteristics Required for Application of Arm. 


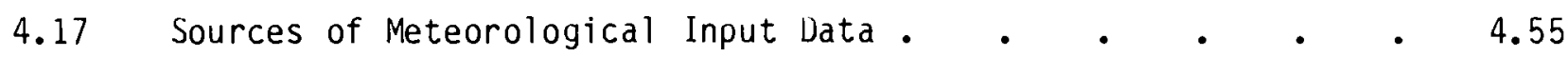

4.18 Flow Data Measured at Gages DPS-4 and LAGS-1 During the
Period of June 1, 1976 to May 31,1977 . $~ . ~$

4.19 Comparison of Initial and Final Values of ARM Calibration

4.20 Comparison of Simulated and Measured Hydrograph
Characteristics for Four Storms on UP Canyon

4.21 Changes in Peak Flow and Runoff Volumes Resulting from

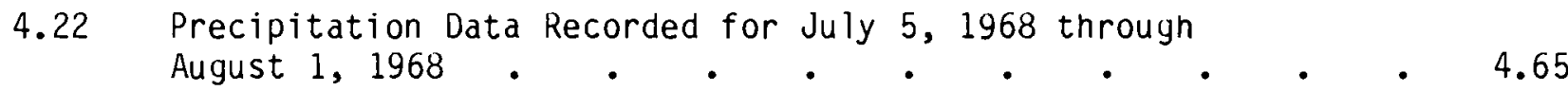

\begin{tabular}{l} 
4.23 Temporal Precipitation Distributions Assumed for 50-yr \\
Flood Event. \\
\hline
\end{tabular}

4.24 Peak Flows Simulated by ARM for the 50-yr Flood $\quad$ • $\quad$ • 4.66

4.25 Channel Information for Acid-Pueblo-Lower Los 4.69

4.26 Comparison of Model and Field Seepage Velocities $\quad$ • $\quad 4.72$

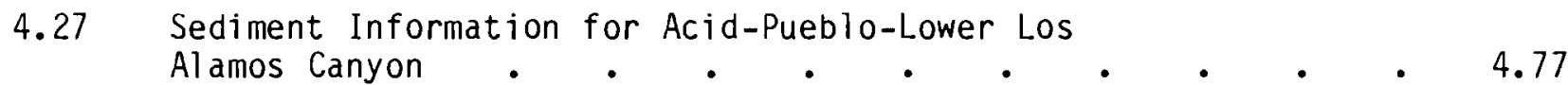

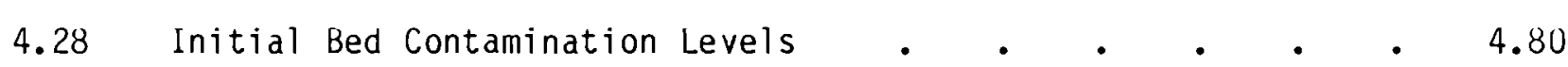

4.29 Plutonium-239 Concentrations per Contaminated Bed Layer
in Acid-Pueblo-Lower Los Alamos Canyon for the 50-yr

Flood Event . . . . . . . . . . . 4.102 
;

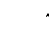

. 
SYMBULS

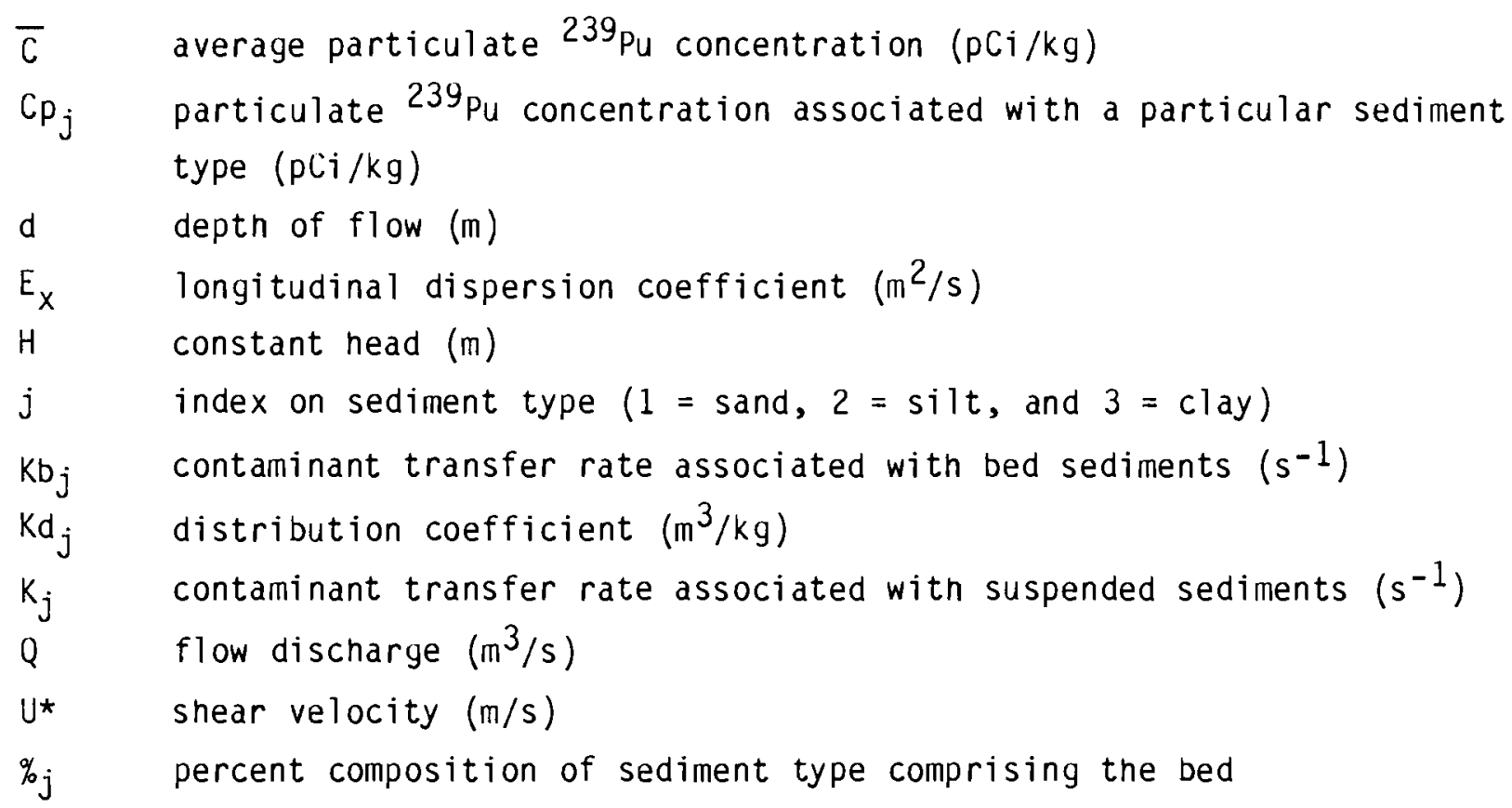




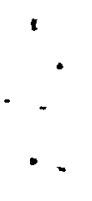

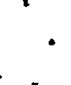




\subsection{INTRODUCTIUN}

Potential environmental impacts from radionuclides released into the aquatic environ must be assessed to ascertain potential levels at locations downstream of release points. Researchers at the Pacific Northwest Laboratory (PNL) have been active for a number of years in developing, modifying, and updating contaminant transport codes pertaining to various aquatic environments (i.e., rivers, lakes, estuaries, reservoirs, oceans, and bays) (Unishi et al. 1981). Under this study, the transport of radionuclides in Acid, Pueblo, and lower Los Alamos Canyons, New Mexico was simulated for a precipitationgenerated flood event with a possible return period of $50 \mathrm{yr}$ to help determine if potential downstream impacts might occur. The 50-yr event was chosen in an attempt to simulate a critical event (i.e., one which may transport significant amounts of ${ }^{239} \mathrm{Pu}$ downstream and deposit them into lower Los Alamos Canyon. The location of the canyons with respect to each other is presented in Section 4.1 .1$.

In the past, radioactive effluent was discharged into Acid and DP Canyons beginning in 1943 as a result of the Manhattan Engineering District (MED) atomic bomb project. Eighty-four percent of these releases were into Acid Canyon, while only $16 \%$ entered DP Canyon. Data gathered in the Los Alamos area indicate that ${ }^{239} \mathrm{Pu}$ (239 $\mathrm{Pu}$ signifies the sum of $239 \mathrm{Pu}$ and $240 \mathrm{Pu}$ ) exists in larger quantities than other radioactive material (LANL 1981). Plutonium-239 migrates in two forms: dissolved and particulate (adsorbed onto sediment) phases. The in-stream transport of ${ }^{239} \mathrm{Pu}$ in solution is relatively insignificant during runoff events as $\sim 99 \%$ is transported with the sediment in a particulate phase. The bulk of the radionuclide activity is associated with the larger-sized sediments, even though the finer sediments have a greater affinity for contaminants. This is because the larger-sized sediments are much more abundant than the finer ones. In general, the $239 \mathrm{Pu}$ concentrations are above backgrond levels in all of the canyons (LANL 1981): Acid Canyon, middle and lower Pueblo Canyon, and lower Los Alamos Canyon. The nighest concentrations of $239 \mathrm{Pu}$ were reported at the outfall (waste disposal location) in Acid Canyon with the $239 \mathrm{pu}$ concentrations in the channels decreasing as the distance from the outfall increased. 
Sediment-contaminant migration over the last 35 to $40 \mathrm{yr}$, due to runoff events from precipitation and snowmelt, resulted in a major portion of the contaminants in Acid Canyon moving into lower Pueblo Canyon and, to a much smaller degree, lower Los Alamos Canyon. Sixty-seven percent of the plutonium in Pueblo Canyon is located in lower Pueblo Canyon. This is expected because at this location the channel widens and flattens reducing the flow velocity and depositing contaminated suspended sediment.

The banks or inactive channel areas tend to have nigher concentrations than the active cnannel. This is also expected since the runoff events tend to resuspend active channel sediments and transport them downstream. Also, finer sediment with nigher radionuclide concentrations associated with it tends to drift into slower moving inactive channel and bank areas during the runoff event and is trapped and deposited there. In addition, the ephemeral stream flows tend to inundate bank areas less often, so the concentrations of ${ }^{239} \mathrm{Pu}$ remain nigh. The activity level is generally confined to the top $30 \mathrm{~cm}$ of the bed. In general, no consistent vertical distribution of ${ }^{239} \mathrm{Pu}$ exists in the canyons. The inventory in the lower Los Alamos area appears to be in a quasiequilibrium state with annual contaminant inflow roughly equaling contaminant outflow at this time (LANL 1981).

There is a considerable amount of uncertainty in predicting the eventual spatial and temporal distribution of contaminants in the Los Alamos area. Complex phenomena and uncertainty in predicting meteorological events are largely responsible. Basically no data are available on flow rates for estimating flood frequency curves and maximum discharges for summer storms in the canyons (LANL 1981).

Three numerical codes were selected to simulate overland runoff of a precipitation event and the resulting migration and fate of sediment and radionuclides in Acid-Pueblo Canyon. The Agricultural Runoff Management (ARM) model simulated the movement of flow and sediment overland to the stream's edge; the Modified Diffusion Wave with Seepage (MODSEEP) model simulated the in-stream hydrodynamics; and the Transient One-Dimensional Degradation and Migration (TODAM) model simulated the in-stream migration and fate of sediment 
and radionuclides. The codes were calibrated on UP and upper Los Alamos

Canyons with partial records of data which exist for this area. A

precipitation-producing flood event with a possible return period of 50 yr was simulated in the Los Alamos area to investigate the migration of radionuclides downstream toward the Rio Grande.

Chapter 2 presents the conclusions of this study. Chapter 3 presents a brief description of the Multimedia Contaminant Environmental Exposure Assessment (MCEA) methodology. Finally, chapter 4 presents the application of the MCEA methodology to the Los Alamos site. This final chapter includes the overland and in-stream modeling results. 


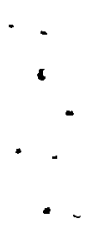




\subsection{CONCLUSIONS}

A complex set of mechanisms controls the migration and fate of contaminants in a given environment. One method of analyzing and simulating natural events which include these mechanisms is to employ mathematical models which are developed for specific pathways and integrated into a systematic, standardized, and cogent methodology. A computer-model-based Multimedia Contaminant Environmental Exposure Assessment (MCEA) methodology was developed by researchers at PNL and LANL to estimate contaminant concentration levels pertaining to several pathways: terrestrial, atmospheric, overland, subsurface, and surface water. The MCEA methodology describes the continuous inigration of radionuclides from one pathway to the next. Numerical models representing the various pathways are compositely coupled to retain scenario flexibility in the modeling approach.

The MCEA methodology was employed in simulating the migration of radionuclides at the Los Alamos site, New Mexico. The transport of radionuclides, specifically ${ }^{239} \mathrm{Pu}$, in Acid, Pueblo, and lower Los Alamos Canyons was simulated for a precipitation-generated flood event with a possible return period of $50 \mathrm{yr}$ to help determine if potential downstream impacts might occur. The 50-yr flood was based on the return period for Pueblo Canyon and not for lower Los Alamos Canyon. Although upper Los Alamos Canyon was included in the model calibration process, it was not included in the application scenario for several reasons:

1. Only $16 \%$ of the total amount of ${ }^{239} \mathrm{Pu}$ released into the environment at the Los Alamos site was released into DP Canyon whereas $84 \%$ was released into Acid Canyon.

2. LANL (1981) reports that ". . interpretations of data from other studies - . suggest at least $75 \%$ of the releases (into) DP Canyon have been transported into lower Los Alamos Canyon." This suggests that only $4 \%$ of the total amount of ${ }^{239} \mathrm{Pu}$ released at the Los Alamos site remains in DP or upper Los Alamos Canyons. 
3. A majority of the ${ }^{239} \mathrm{Pu}$ contamination is located in lower Pueblo Canyon.

4. By modeling Acid-Pueblo-lower Los Alamos Canyon as one canyon and not including flows from upper Los Alamos Canyon or lateral inflow from lower Los Alamos Canyon, an attempt was being made to maximize the possibility for contaminated sediment to deposit in the San Ildefonso Pueblo. By including the flows from upper Los Alamos Canyon, the peak flow discharge would have approximately doubled, if the time to peak of the flood nydrographs from Pueblo and upper Los Alamos Canyons coincided. If the combined flows were used in the simulation, more of the contaminated sediment would have been swept downstream to the Rio Grande, creating less of an effect in the San Ildefonso Pueblo.

5. The increase in flow and sediment from upper Los Alamos Canyon would tend to dilute the contaminant concentrations migrating through lower Los Alamos Canyon.

A modeling scenario was developed so as not to underestimate the possible migration of $239 \mathrm{Pu}$ from Acid and Pueblo Canyons. In instances where data were lacking, conservative estimaes were employed. The following assumptions were adopted for the modeling scenario:

1. The total $239 \mathrm{pu}$ inventory used as initial conditions for the modeling scenario was 1.96 times the estimated inventory of ${ }^{239} \mathrm{pu}$ on soils and sediments as reported by LANL (1981). The initial inventory of ${ }^{239} \mathrm{Pu}$ is larger than the estimate presented by LANL (1981) because the contaminant bed concentrations representing the initial conditions for the modeling scenario were assumed to extend $30 \mathrm{~cm}$ into the bed of the channel, whereas the actual depth of $239 \mathrm{Pu}$ contamination at locations other than those recorded by LANL (1981) could be $<30 \mathrm{~cm}$. Thirty centimeters was chosen as the depth of each bed layer a) because all recorded data as presented by LANL (1981) indicated bed contamination extended no further than $30 \mathrm{~cm}$, b) so as not to 
exclude those areas which were contaminated to a depth of $30 \mathrm{~cm}$, and $c$ ) because no other data identifying the possible depth of contamination were reported.

2. In the cases where a vertical distribution of contaminant concentrations was provided, a weighted average for the ${ }^{239} \mathrm{Pu}$ concentration was used based on depth for that section of the bed. The recorded depths of contamination extended $30 \mathrm{~cm}$ into the bed of the channel with no contamination recorded below this deptn.

3. No flow from upper Los Alamos Canyon was included in the modeling scenario for reasons mentioned above.

4. No flow or sediment from the overland segments in lower Los Alamos Canyon was included in the modeling scenario. Assumptions 3 and 4 were made to try to maximize the deposition of contaminated sediments in lower Los Alamos Canyon.

5. A small overland area of high ${ }^{239} \mathrm{Pu}$ concentration in Acid Canyon was simulated as a channel section in order to maximize contaminant migration from this area. The current simulation for the 50-yr flood event revealed that the first channel section experienced sediment deposition, but not bed erosion. Hence, this assumption had little impact on the outcome of the ${ }^{239} \mathrm{Pu}$ distribution.

6. Since cross sections for lower Pueblo Canyon were unavailable, they were estimated from a topographic map with 5 -ft contour intervals. Unfortunately, as it turned out, the flow depths predicted for the $50-y r$ flood event were $<5 \mathrm{ft}$ in depth at all cross sections. The 5-ft contour intervals do not contain the necessary precision for accurately identifying the wide channel existing in lower Pueblo Canyon. Although with this assumed channel shape the movement of ${ }^{239} \mathrm{Pu}$ from this area would be maximized, these cross sections were employed in this study because better information regarding the cross-sectional shapes did not exist. 
7. The sand size assumed for the modeling scenario was $0.76 \mathrm{~mm}$. This size represented the sand size measured in lower Pueblo Canyon where the majority of $239 \mathrm{Pu}$ inventory exists. Most of the median sand sizes comprising the beds of Acid, Pueblo, and Los Alamos Canyons are larger than that in lower Pueblo Canyon (and some canyons have smaller sand sizes). By simulating the smaller sediment size, a) the size which has a majority of the 230pu adsorbed to it is being represented in the modeling scenario, and b) the contaminated sediment has a better chance of being entrained into the flow and of migrating into lower Los Alamos Canyon. It snould be noted that the numerical code simulating the movement of sand accepts as input only one median sand size value.

Two environs of the MCEA methodology were compositely combined for the modeling scenario. They included the overland and in-stream environs. The Agricultural Kunoff Management (ARM) model simulated the overland movement of water and sediment to stream's edge; the Modified Diffusion Wave with Seepage (MODSEEP) hydrodynamic model simulated the movement of the flood wave in stream; and the Transient One-Dimensional Degradation and Migration (TODAM) model simulated the in-stream contaminant movement.

The following conclusions were derived from this study:

1. Cohesive sediment (i.e., silts and clays) associated with nigher radioactivity was generally carried through the system with very little deposition. Sand represented the major sediment type being carried through the system.

2. Due to its narrow cross-sectional shape, the portion of lower Los Alamos Canyon just upstream of the San Ildefonso Pueblo generally experienced degradation. The portion of lower Los Alamos Canyon on the San Ildefonso Pueblo, because of milder slope and broader crosssectional shape, generally experienced aggradation.

3. Sand represented the sediment size fraction carrying the major portion of the $239 \mathrm{Pu}$. This was expected since sand comprises $\sim 98 \%$ of the channel bed. 
4. Lower Pueblo Canyon did not represent a region where an excessive inventory of ${ }^{239} \mathrm{Pu}$ was deposited. The full effect of the wide cross sections which are characteristic of this region were not fully realized in the modeling scenario as the cross sections were estimated from topographic maps with 5-ft contour intervals. As it turned out, flow depths were $<5 \mathrm{ft}$.

5. The dissolved phase of ${ }^{239} \mathrm{Pu}$ represented $<1 \%$ of the total ${ }^{239} \mathrm{Pu}$ movement downstream. Most of the ${ }^{239} \mathrm{pu}$ was migrating downstream adsorbed to sediments.

6. The net amount of $239 \mathrm{pu}$ resuspended from channel sections experiencing degradation for the 50-yr flood event represented approximately $1 \%$ to $2 \%$ of the initial ${ }^{239} \mathrm{Pu}$ inventory comprising the channel bed.

7. The average contaminant bed concentration for ${ }^{239} \mathrm{Pu}$ (i.e., weighted according to the depth of the respective bed layer) in lower Los Alamos Canyon decreased by $5.4 \%$.

8. Approximately $27 \%$ of the total ${ }^{239} \mathrm{Pu}$ contamination resuspended from the entire bed (based on the assumed channel cross sections) for the $50-y r$ flood event originated from lower Pueblo Canyon.

9. For the 50-yr flood event, the simulation results tend to indicate that any contaminant resuspended upstream of lower Pueblo Canyon also deposits upstream of lower Pueblo Canyon.

10. The ${ }^{239} \mathrm{Pu}$ inventory in lower Los Alamos Canyon after the 50-yr flood event simulation increased by approximately 1.1 times.

11. Plutonium-239 inventory migrating downstream followed the same patterns as that experienced by the sediment. In areas of deposition, a drop in the ${ }^{239} \mathrm{pu}$ migration occurred as well as an increase in ${ }^{239} \mathrm{Pu}$ inventory in the bed at the location. In areas of sediment resuspension, the ${ }^{239} \mathrm{Pu}$ inventory migrating downstream increased with a corresponding decrease in ${ }^{239} \mathrm{Pu}$ inventory in the bed. 
12. Fifty-five percent of the ${ }^{239} \mathrm{Pu}$ reaching the San Ildefonso Pueblo in lower Los Alamos Canyon originated from lower Los Alamos Canyon.

13. Fifty-six percent of the ${ }^{239} \mathrm{Pu}$ contamination reaching the San Ildefonso Pueblo in lower Los Alamos Canyon was carried through towards the Rio Grande. 


\subsection{MULTIMEDIA CUNTAMINANT ENVIRONMENTAL EXPOSURE ASSESSMENT METHODOLOGY}

There has been an ever-increasing concern about assessing and controlling the potential environmental impacts of toxic chemicals and radionuclides in the environment. Before the impact of contaminant releases can be assessed, contaminant exposure levels in the environment due to the transport and fate of released contaminants must be determined. A computer-model-based Multimedia Contaminant Environmental Exposure Assessment (MCEA) methodology was developed to estimate contaminant concentration levels in several environs: terrestrial, atmospheric, overland, subsurface, and surface water. The goal was to develop a general methodology which permitted a) the consideration of site-specific conditions and characteristics, b) the simulation of realistic environmental transport mechanisms in multimedia, c) the comparative evaluation of the consequences of various environmental scenarios, and d) the flexibility to apply to a wide range of conditions with reasonable cost and effort.

Because complex phenomena are involved in contaminant migration and fate in a multimedia environment (e.g., air, water, and soil), it is very difficult to assess the exposure levels of contaminants in the environment. Underestimation of exposure levels may result in unacceptable damage to man and ecological systems. However, overestimation of exposure levels and potential risks may result in unnecessary expense for additional waste treatments imposed on the general industry in question. Multimedia mathematical models can integrate such complex transport and fate mechanisms into a single framework so that potential levels of exposure can be more accurately evaluated.

A multimedia environmental exposure assessment methodology can be obtained by either a fully coupled multimedia modeling approach or a composite multimedia modeling approach. The fully coupled approach uses a model whose submodels for each pathway (air, soil, groundwater, and surface water) are integrated parts of the overall multimedia model. With a fully coupled approach, each submodel is allowed to interact (feed and feedback) with other submodels. In this approach, the various pathway submodels in a fully coupled multimedia model generally become oversimplified to achieve understandable input data streams, a reasonable computer core size and reasonable run times. 
On the other hand, a composite multimedia methodology is assembled by selecting and loosely combining appropriate models for various patnways. In this way, more realistic individual patnway models are retained as independent models. For a given problem, the most suitable pathway models can be assembled in this composite approach. Since only necessary models will be selected for each problem addressed, the methodology is flexible to each problem and possibly less expensive to run. In addition, the patnway models for each given media are replaceable. Where applicable, a common data base ainong various pathways for different media is desirable.

Coupling these individual pathway models into a composite multimedia methodology is achieved by directing the output file from one pathway model to the input file of the next pathway model. Specific feedback between the various media pathways, which is the main justification for completely coupled multimedia models, is nandled by analysis of the problem of concern in terms of primary and secondary pathways for each medium and the approriate interactions of these models and their results.

Once contaminants are released to the environment, they can undergo complex processes of transport, degradation and decay, transformation, intermedia transfer anong air, overland, yroundwater, surface water, and biological uptake. The interactions of various media pathways and linkage to man are illustrated in Figure 3.1.

The contaminant pathways applicable to this study are represented by land and water and sediment environs in Figure 3.1. The contamination occurs initially in the bed of the stream channel adsorbed onto bed sediments. Water and sediment from the land surface enters the stream channel and entrains the contaminated sediment into the channel flow where it migrates downstreain to be deposited. From here the potential exists for interfacing with aquatic life, potable water, etc., and eventually to interface with man. Any and all of these interactions may be insignificant and therefore harmless to the various environs. 


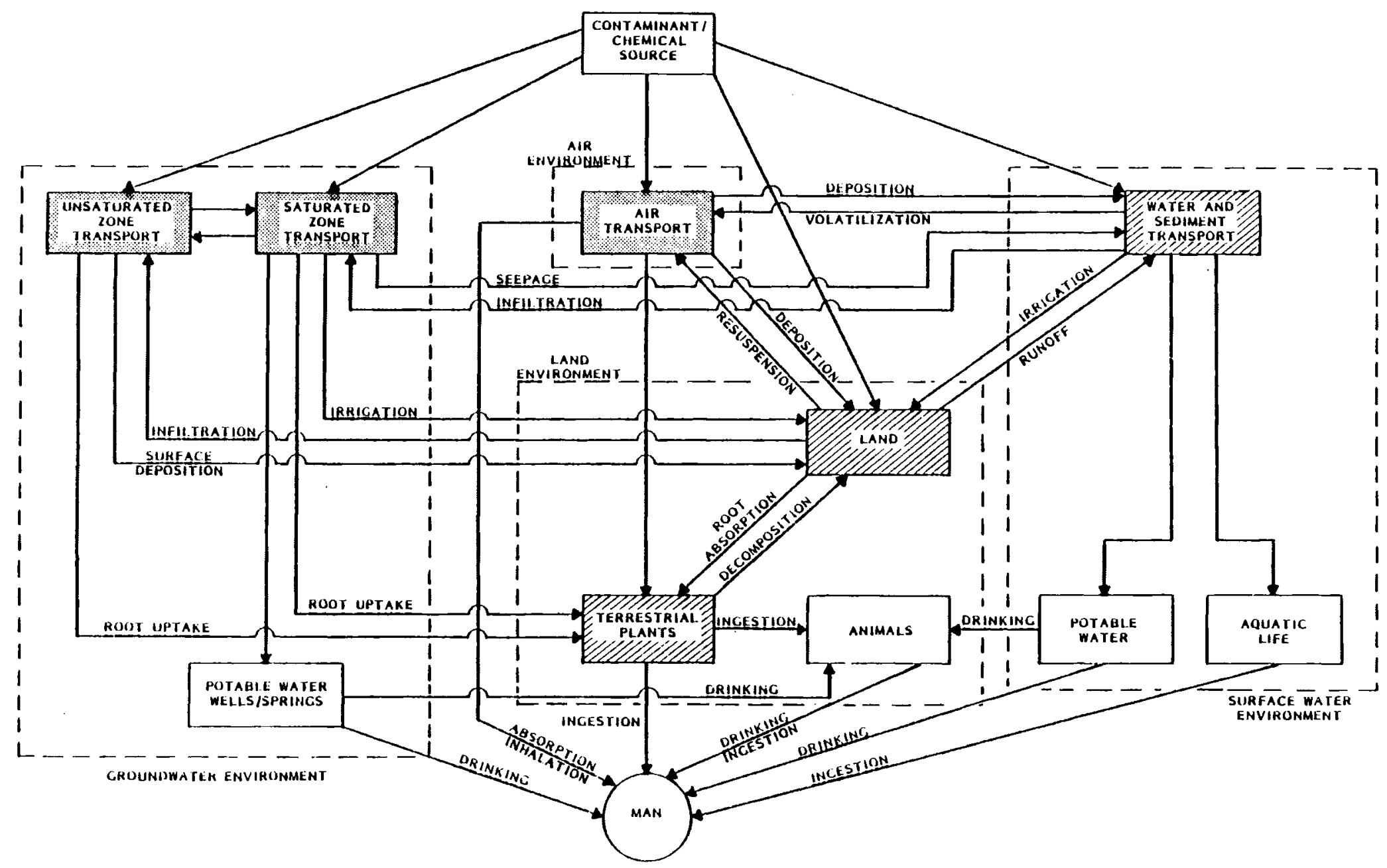

FIGURE 3.1. Schematic Diagram Illustrating the Interactions Between the Various Transporting Media and How They Affect Man Through His Environment 



\subsection{APPLICATION UF THE MCEA METHODOLOGY}

The MCEA methodology represents a fairly comprehensive scheme for evaluating the migration and fate of contaminants in the environment. Of the five environs (i.e., terrestrial, atmospheric, subsurface, overland, and surface water) considered by the methodology, two were employed in the modeling scenario herein: overland and surface water. Although state-of-the-art models were selected for each component of the integrated methodology, the coupling of these models required careful attention as to the mass conservation between components, the differences in temporal and spatial resolution among selected models, and the selection of appropriate interfaces between models, based on the physical, chemical, and contaminant processes involved. In particular, the models and methodology were selected based on current understanding of radionuclide migration and fate, our efforts to perform the analysis, and the availability of required data.

The following topics are addressed in this chapter: background information pertaining to the Los Alamos site, pathway and model selection, modeling methodology and scenario, and the calibration and application results of the various models employed.

\subsection{LUGISTICS UF APPLYING THE METHODOLUGY}

4.1.1 Formerly Utilized Sites Remedial Action Program

Background information describing the LoS Alamos area and its history is presented below. Much of this information was originally presented by LANL (1981) in the form of a report for the Formerly Utilized Sites Remedial Action Program (FUSRAP) sponsored by the U.S. Department of Energy (DOE). Figures $4.1,4.2$, and 4.3 describe the site pertaining to the information presented in this section. Figure 4.1 presents the topography of the Los Alamos area in New Mexico; Figure 4.2 presents a schematic representation of the Los Alamos area; and Figure 4.3 presents the land ownership or management in the study area. 


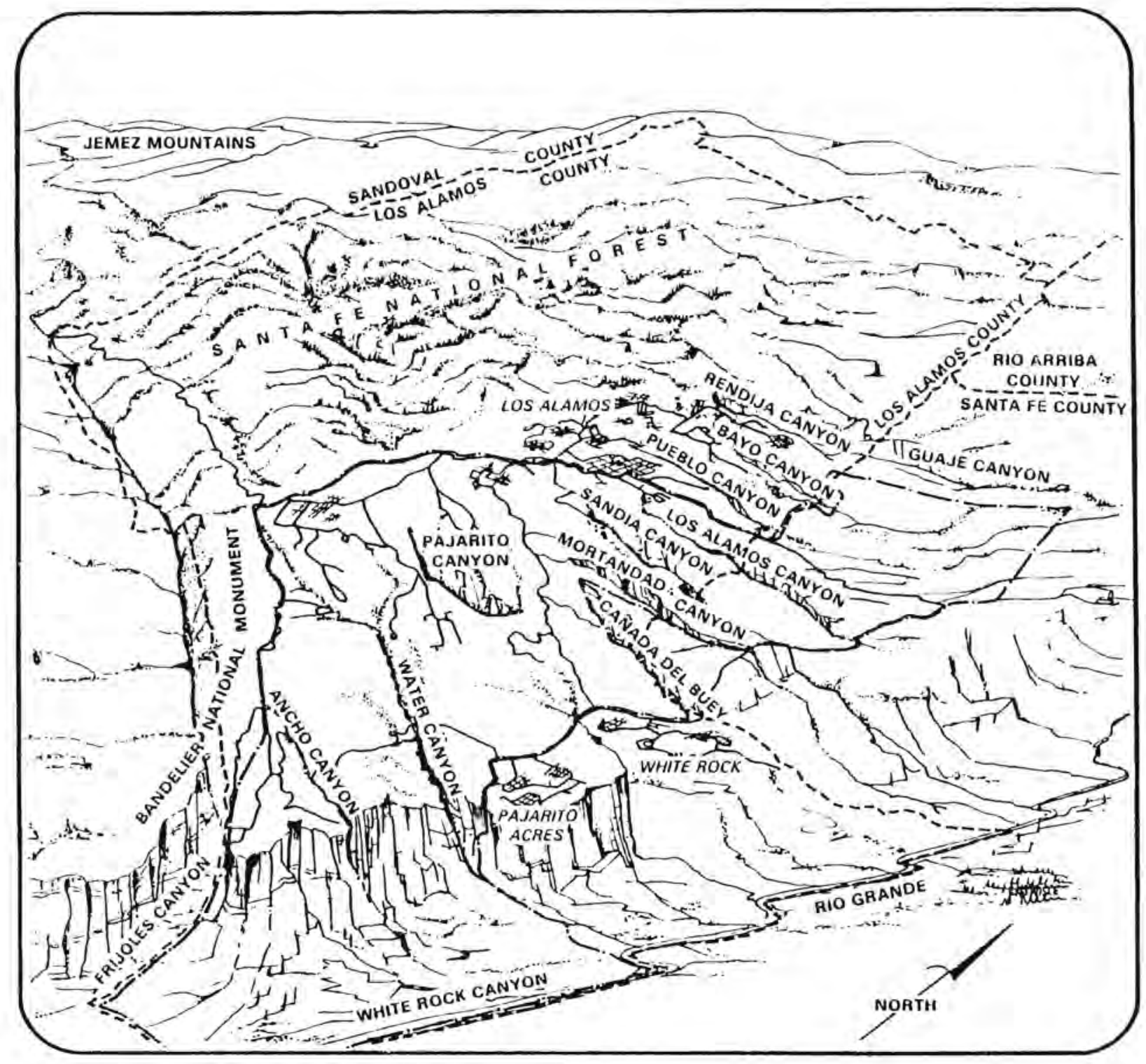

FIGURE 4.1. Topography of the Los Alamos Area in New Mexico 


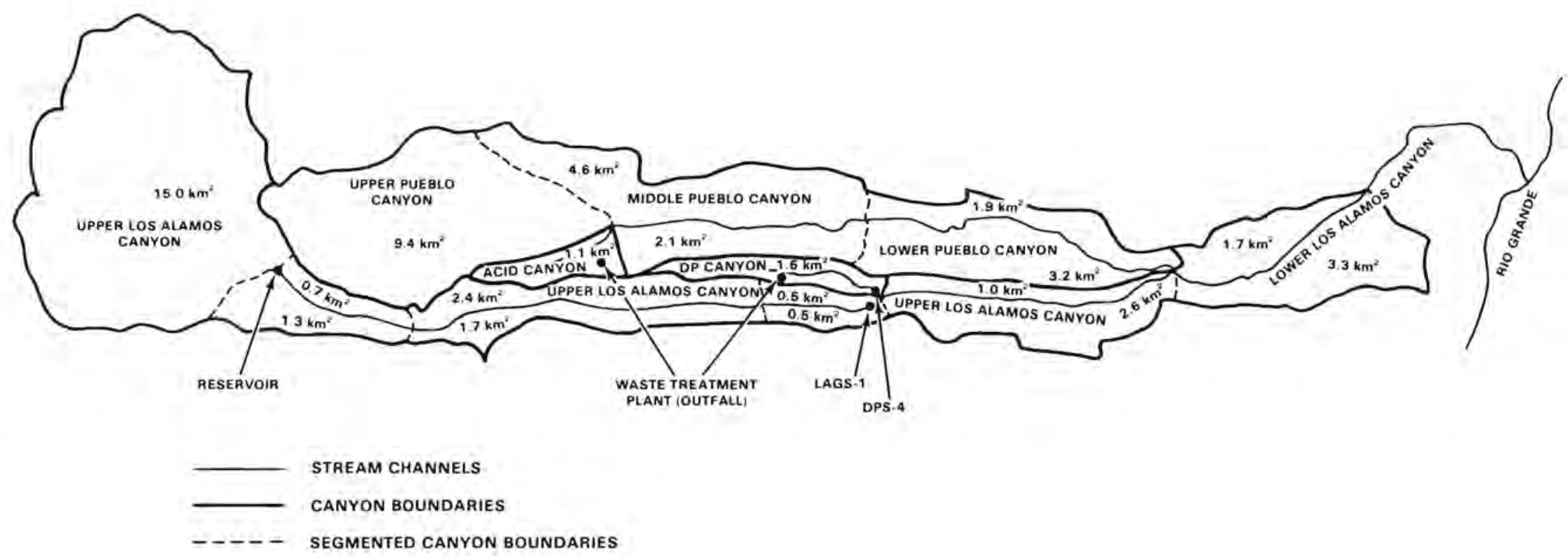

FIGURE 4,2. Acid-Pueblo and DP-LOS Alamos Canyons 


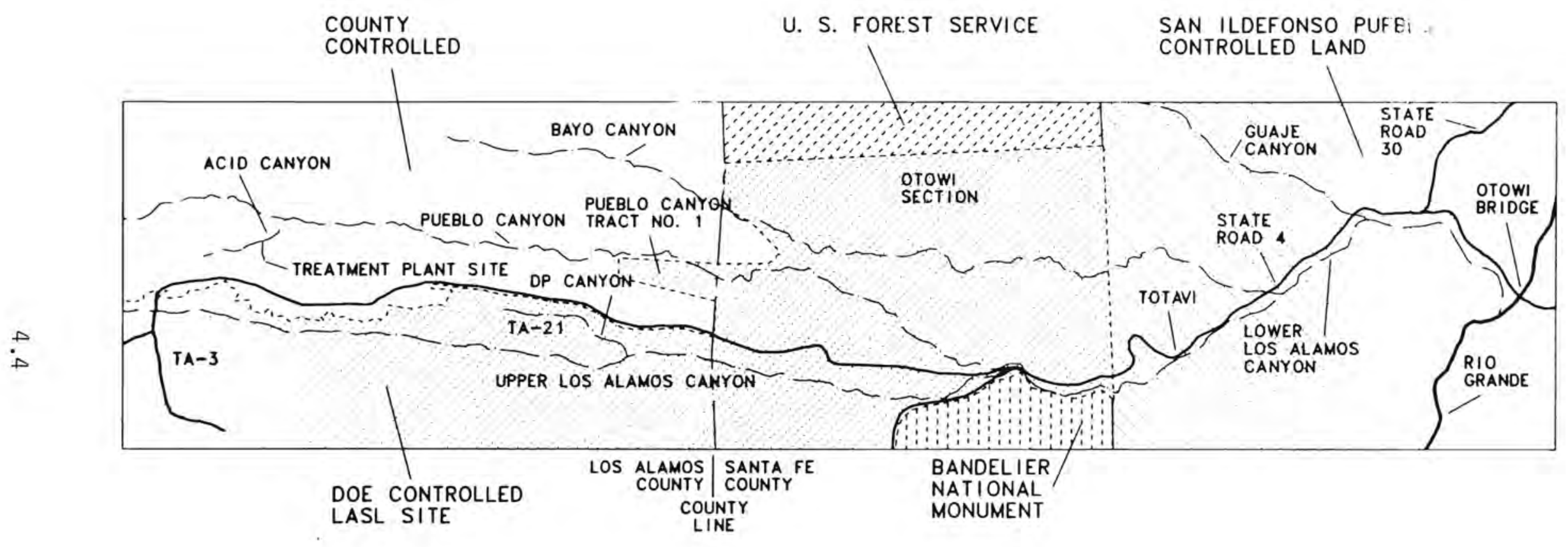

FIGURE 4.3. Land Ownership or Management in Study Area (LANL 1981) 
"Liquid radioactive wastes were generated by research with nuclear materials at Los Alamos, New Mexico, for the World War I I Manhattan Engineering District (MED) atomic bomb project starting in 1943, and subsequently by work conducted for the Atomic Energy Commission (AEC). Untreated effluents were discharged into Acid Canyon (Figure 4.2) from 1944 until 1951. A treatment plant was constructed on the rim of Acid Canyon and discharged treated effluents from 1951 until 1964. Following decommissioning of the plant and decontamination of the site and part of Acid Canyon, ownership of the property was transferred to Los Alamos County by the Federal Government in 1967.

"Acid Canyon is a small branch of Pueblo Canyon, which in turn, joins lower Los Alamos Canyon. Acid Canyon and part of Pueblo Canyon are currently controlled by the County of Los Alamos. The federal government has an easement across the county land generally following the course of the normally dry channel from the discharge point at the head of Acid Canyon for collecting samples and maintaining test wells. The remainder of Pueblo Canyon and a small part of lower Los Alamos Canyon are currently controlled by the DUE. Most of lower Los Alamos Canyon, down to the point where it joins the Rio Grande, is controlled by the San Ildefonso Indian Pueblo (Figure 4.3). Some residual radioactivity attributable to the effluents is found on soils and sediments in the channels of each of these canyons. Intermittent runoff events transport and redistribute sediments periodically" (LANL 1981). Current land use includes occasional recreational use of Acid and Pueblo Canyons, commuter traffic on State koad 4 in lower Los Alamos Canyon, several households, a commercial sand and gravel operation, and some cattle grazing in lower Los Alamos Canyon (LANL 1981).

"Some highlights of the occurrence and distribution of radioactivity on the sediments and soils affected by the liquid effluents may be useful in evaluating future management alternatives and describing possible future changes from natural hydrologic processes. Transuranic elements. . .are present in all affected areas at levels with statistical significance above those normally observed as background in northern New Mexico from world wide fallout. The highest concentrations occur in areas of limited extent at the 
county-owned site of the former waste treatment plant (in Acid lanyon). . .and (along the) natural drainage course which carried the untreated effluent. Within the canyons, most contaminated material is near-surface (<U.5 $\mathrm{II})$. The largest average concentrations and about $16 \%$ of the total inventory uccur in the county-owned Acid Canyon. . . Intermediate average concentrations and about $12 \%$ of the inventory occur in the county-owned middle Pueblo canyon. similar concentrations, but about $67 \%$ of the inventory, occur in UUE-controlled lower Pueblo Canyon. The lowest average concentrations, and about $6_{i}^{\circ}$ of the inventory, occur in lower Los Alamos Canyon (on San Ildefonso Indian Pueblo land). - Uther radioactive contaminants including fission products are present at low but statistically significant levels above backyround in some, but not all, areas. Their major contribution to estimated risks is from external penetrating radiation that would be experienced only in the immediate vicinity of the contanination, e.g., the channels and banks" (LANL 1981).

"Major future runoff events in Pueblo canyon could result in movenent of the large proportion of the transuranic inventory, now accumulated in the broad channel of lower Pueblo Canyon, further downstream and into lower Los Alamos Canyon. - - During the year of a major event, it is possible that the average concentration of plutonium on suspended sediments in the kio Grande in White Rock Canyon down to Cochiti Dam (about $20 \mathrm{~km}$ downstream from the junction with Los Alamos Canyon) would be higher than that typically observed in the river due to worldwide fallout. The maximum levels would be about the same as the concentration considered by the EPA to be average for soils throuynout the U.S." (LANL 1981).

\subsubsection{Los Alamos and Puedlo Canyons}

The area under study, as presented in Figure 4.4, is lucated in northcentral New Mexico about $100 \mathrm{~km}$ (62 $\mathrm{mi}$ ) north-northeast of Albuquerque and $40 \mathrm{~km}$ (25 mi) northwest of Santa Fe (LANL 1981). Two major drainaye basins comprise the overall catchinent: DP-Los Alarios (DP-LA) Canyon and Acid-Pueblo $(A-P)$ Canyon. The drainage basins are east-west oriented with UP and Pueblo Canyons as tributaries of Los Alamos Canyon (see Figure 4.2). The area has a semi-arid, continental mountain climate (Unishi, Whelan, and Skaggs 1982). The vegetational and climatic variation are commensurate with the elevational 


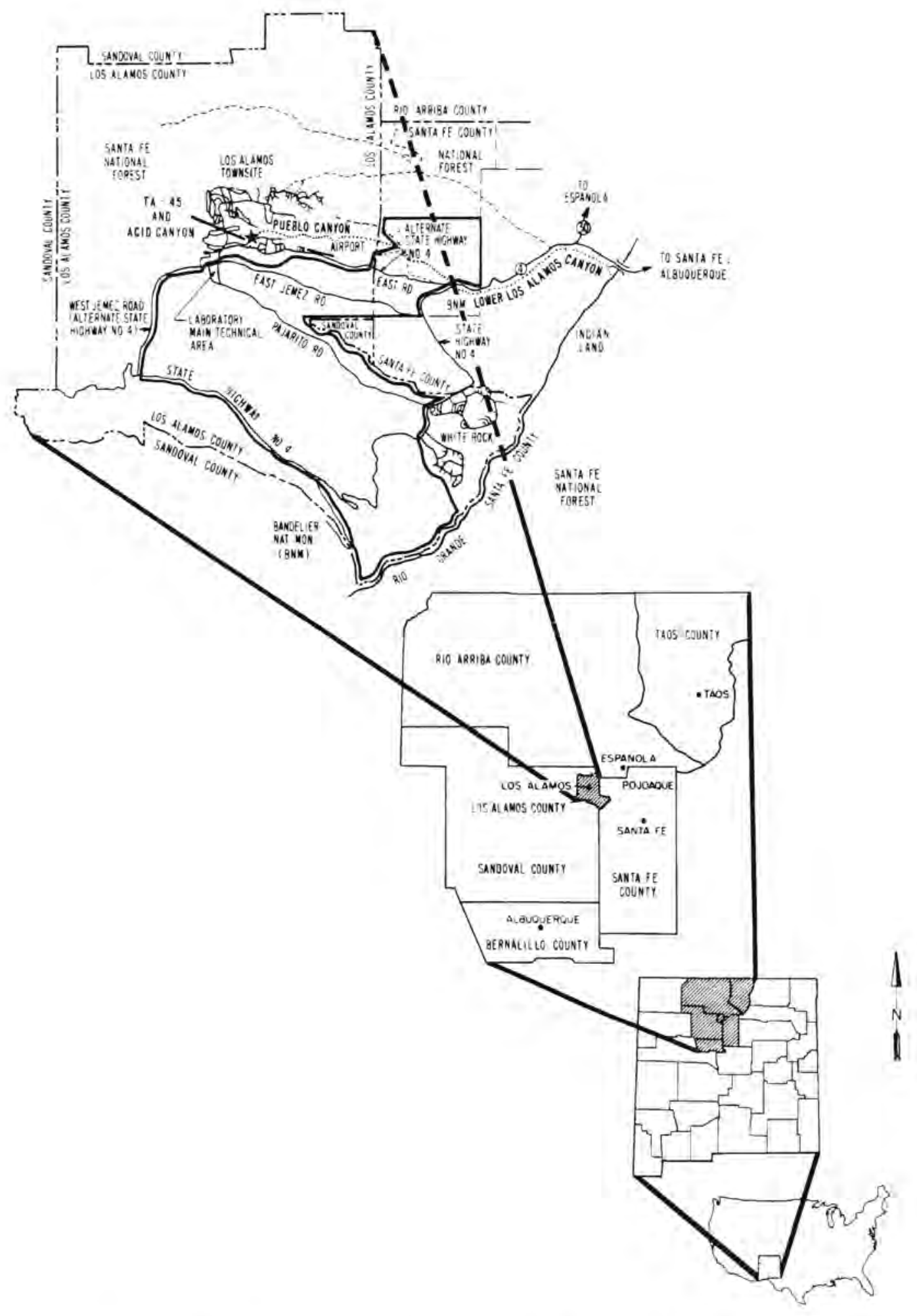

FIGURE 4.4. Regional Location of Study Area (LANL 1981) 
gradation westward from the Rio Grande (LAINL 1981). The transition zones of overstory vegetation range from juniper and grasslands at lower elevations along the Rio Grande to fir, spruce, and subalpine yrasslands at the nigner elevations (LAINL 1981). In general, the catchment has grasses and shrubs growing along the banks with some boulders and blocks dislodged fron the canyon walls. For the most part, canyon walls are steep with a narrow canyon floor. The watershed characteristics of the individual catchments are presented in Table 4.1.

\section{Meteorological Londitions}

Moisture that infiltrates the ground froin precipitation or snowmelt penetrates about 4 to $5 \mathrm{~m}$ at a maximum and is re-evaporated into the air (Wheeler 1979). Streams are intermittent by nature with surface runoff occurring in association with summer thunderstorms, with a highly variable intensity and distribution. The remaining precipitation occurs as snow during the winter months. In addition, the average annual precipitation increases from about $23 \mathrm{~cm}$ along the kio lirande to as much as $76 \mathrm{~cm}$ along the crest of the mountains to the west (LANL 1981).

The average July temperature at the lower elevations is about $23^{\circ} \mathrm{C}\left(73^{\circ} \mathrm{F}\right)$, and on the plateau about $19^{\circ} \mathrm{C}\left(66^{\circ} \mathrm{F}\right)$, while average January temperatures are $-6^{\circ} \mathrm{C}\left(21^{\circ} \mathrm{F}\right)$ and $-7^{\circ} \mathrm{C}\left(19^{\circ} \mathrm{F}\right)$, respectively (LANL 1981). The temperature arops even lower as the elevation increases and snow stays on the peaks until late May or early June. Pan evaporation for the laboratory area is estimated at about $150 \mathrm{~cm} / \mathrm{yr}$. Considerable variability can be expected due to differences in elevation and aspect, but no data exists (Wheeler 1979).

\section{Sediment Distributions}

Some data does exist regarding the distribution of sediments and radionuclides in OP-LA and A-P Canyons. The sediments in A-P Canyon result from chemical and mechanical weathering of acid volcanic rock. The granules are composed mainly of tuff, pumice, latite, and rhyolite rock fragments with minor amounts of quartz and sanidine crystals (LANL 1981). The fractions of fine to coarse sand consist mainly of quartz and sanidine crystals and crystal fragments with minor amounts of rock fragments. The silt and clay fractions 
TABLE 4.1. Watershed Characteristics (a)

\begin{tabular}{|c|c|c|c|c|}
\hline Canyon & $\begin{array}{c}\text { Drainage } \\
\text { Area }\end{array}$ & $\begin{array}{l}\text { Average } \\
\text { Channel } \\
\text { Gradient } \\
\end{array}$ & $\begin{array}{l}\text { Channe l } \\
\text { Length }\end{array}$ & $\begin{array}{l}\text { Elevation } \\
\text { Urop in } \\
\text { Catchment } \\
\end{array}$ \\
\hline$D P$ & $\begin{array}{l}1.6 \mathrm{~km}^{2} \\
\left(0.6 \mathrm{mi}^{2}\right)\end{array}$ & 0.061 & $\begin{array}{l}1.8 \mathrm{~km} \\
(1.1 \mathrm{mi})\end{array}$ & $(700 \mathrm{ft})(\mathrm{c})$ \\
\hline Los Al amos & $\begin{array}{l}25.9 \mathrm{~km}^{2} \\
\left(10.0 \mathrm{mi}^{2}\right)(\mathrm{b})\end{array}$ & 0.026 & $\begin{array}{l}14.5 \mathrm{~km} \\
(9.0 \mathrm{mi}) \\
(b, c, d)\end{array}$ & $\frac{1280 \mathrm{III}}{(4200 \mathrm{ft})}(\mathrm{c})$ \\
\hline Acid & $\begin{array}{c}1.1 \mathrm{~km}^{2} \\
\left(0.4 \mathrm{mi}^{2}\right)(\mathrm{c})\end{array}$ & -- & -- & $(460 \mathrm{ft})(\mathrm{c})$ \\
\hline Pueblo & $\begin{array}{l}21.2 \mathrm{~km}^{2} \\
\left(8.2 \mathrm{mi}^{2}\right)(\mathrm{c})\end{array}$ & 0.017 & $\begin{array}{l}9.8 \mathrm{~km} \\
(6.1 \mathrm{mi})\end{array}$ & $\frac{1158 \mathrm{~m}}{\left(3800^{\mathrm{ft}}\right)}(\mathrm{c})$ \\
\hline UP-LA & $\begin{array}{l}27.5 \mathrm{~km}^{2} \\
\left(10.6 \mathrm{mi}^{2}\right)(b)\end{array}$ & -- & -- & -- \\
\hline$A-P$ & $\begin{array}{l}22.3 \mathrm{~km}^{2} \\
\left(8.6 \mathrm{mi}^{2}\right)\end{array}$ & -- & -- & -- \\
\hline
\end{tabular}

(a) Information gathered from LANL (1981), Purtymun (1974a, 1974b) and topographic and watershed characteristic maps.

(b) Upstream of Pueblo-Los Alamos Canyon confluence.

(c) Estimate.

(d) Downstream of the reservoir on Los Alamos Canyon (see Figure 4.2).

(e) Uownstream of Acid-Pueblo Canyon Confluence.

are composed mainly of clay minerals, montmorillonite, and illite (LANL 1981). Tables 4.2 and 4.3 present sediment distributions (as percent finer by weight) at various locations (as indicated by Figure 4.5) on Acid and Pueblo Canyons. Figures 4.6 and 4.7 present the cumulative logarithmic probability size-frequency distributions (sediment size versus percent finer by weight) corresponding to Tables 4.2 and 4.3 , respectively.

In Los Alamos Canyon, sediments are derived from weathering of the Tschiconia Formation and Bandelier Tuff. The channel in Los Alamos canyon is composed of gravel and sands with cobbles and boulders. In DP Canyon, the larger material is composed of tuff which breaks down rapidly with transport 
TABLE 4.2. Particle-Size Distribution of Channel Sediments from Acid-Pueblo Canyon (LANL 1981)

\begin{tabular}{|c|c|c|c|c|c|c|c|c|c|}
\hline \multirow[b]{3}{*}{ Classification } & & & \multicolumn{7}{|c|}{ Distribution (\% by Weight) } \\
\hline & \multirow{2}{*}{\multicolumn{2}{|c|}{$\begin{array}{l}\text { Size Range } \\
(\mathrm{mm})\end{array}$}} & \multirow{2}{*}{\multicolumn{2}{|c|}{$\begin{array}{l}\text { Acid Canyon } \\
\text { Acid } \\
\text { AC-4 Weir } \\
\end{array}$}} & \multicolumn{5}{|c|}{ Pueblo Canyon } \\
\hline & & & & & $P C-1$ & $P C-5$ & $\mathrm{PC}-7$ & $\mathrm{PC}-9$ & APS \\
\hline Granules & 2.360 & 3.960 & 4.5 & 6.5 & 3.0 & 10.5 & 5.0 & 2.0 & \\
\hline Very coarse sand & 1.170 to & 2.360 & 47.0 & 42.5 & 36.5 & 34.5 & 28.0 & 10.0 & 17 \\
\hline Coarse sand & 0.589 to & 1.170 & 44.0 & 39.5 & 50.5 & 37.0 & 31.0 & 40.0 & \\
\hline Medium sand & to & & 2.0 & & 7.0 & 11.0 & 19.0 & 21.0 & \\
\hline Fine sand & 0.147 & 0.295 & 1.0 & 1.5 & 1.0 & 3.0 & 11.5 & 9.5 & \\
\hline Very fine sand & 0.074 to & 0.147 & 1.0 & 1.0 & 0.5 & 1.5 & 2.5 & 6.5 & \\
\hline Silt and clay & & $<0.0$ & 0.5 & 3.0 & 1.5 & 3.0 & 3.0 & 11.0 & \\
\hline
\end{tabular}
TABLE 4.3. Particle-Size Distribution of Channel Sediments
from Acid and Pueblo Canyons (a)

\begin{tabular}{|c|c|c|c|c|}
\hline \multirow{2}{*}{\multicolumn{2}{|c|}{$\begin{array}{c}\text { Size Range } \\
(\mathrm{mm})\end{array}$}} & \multicolumn{3}{|c|}{$\frac{\text { Distribution (\% by Weight) }}{\text { Acid-Pueblo Canvon }}$} \\
\hline & & $\frac{A}{A P-I}$ & $\frac{\text { Pueblo }}{\text { AP-II }}$ & $\frac{\text { Canyon }}{A P-I I I}$ \\
\hline$>2.000$ & & 23.82 & 8.14 & 7.44 \\
\hline 1.168 to & 2.000 & 15.83 & 16.95 & 20.55 \\
\hline 0.500 to & 1.168 & 32.04 & 39.70 & 49.10 \\
\hline 0.105 to & 0.500 & 22.50 & 21.91 & 19.38 \\
\hline 0.053 to & 0.105 & 1.48 & 6.42 & 1.43 \\
\hline & $<0.053$ & 4.33 & 6.88 & 2.10 \\
\hline
\end{tabular}

(a) Samples taken 17.8 to $25.4 \mathrm{~cm}$ from top by staff at the Los Alamos National Laboratory.

during storm runoff. Tables 4.4 through 4.6 present sediment distributions (as percent by weight) at various locations (as indicated by Figure 4.5) in DP and Los Alamos Canyons. Figures 4.8, 4.9, and 4.10 present the curnulative logarithmic probability size-frequency distributions (sediment size versus percent finer by weight) corresponding to Tables 4.4, 4.5, and 4.6, respectively. As these tables indicate (Tables 4.2 through 4.6 ) the bulk of the bed sediment is fairly large (coarse sand). The median-sized bed sediment diameters for Tables 4.2 through 4.6 ranged from $0.43 \mathrm{~mm}$ to $>2.00 \mathrm{~mm}$. 


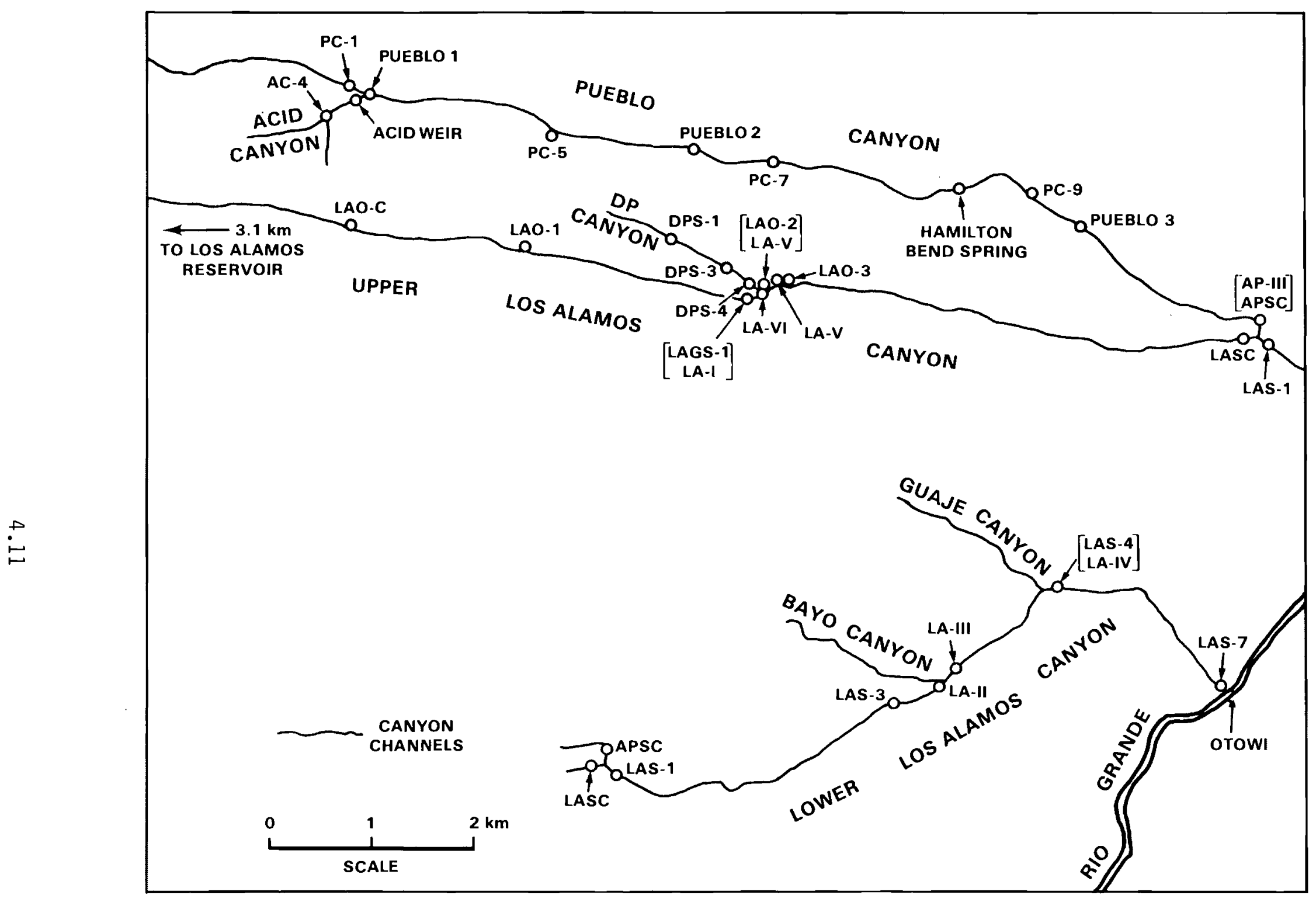

FIGURE 4.5. Monitoring Net in Acid-Pueblo DP-Los Alamos Canyons, 1949-1975 (LANL 1981) 


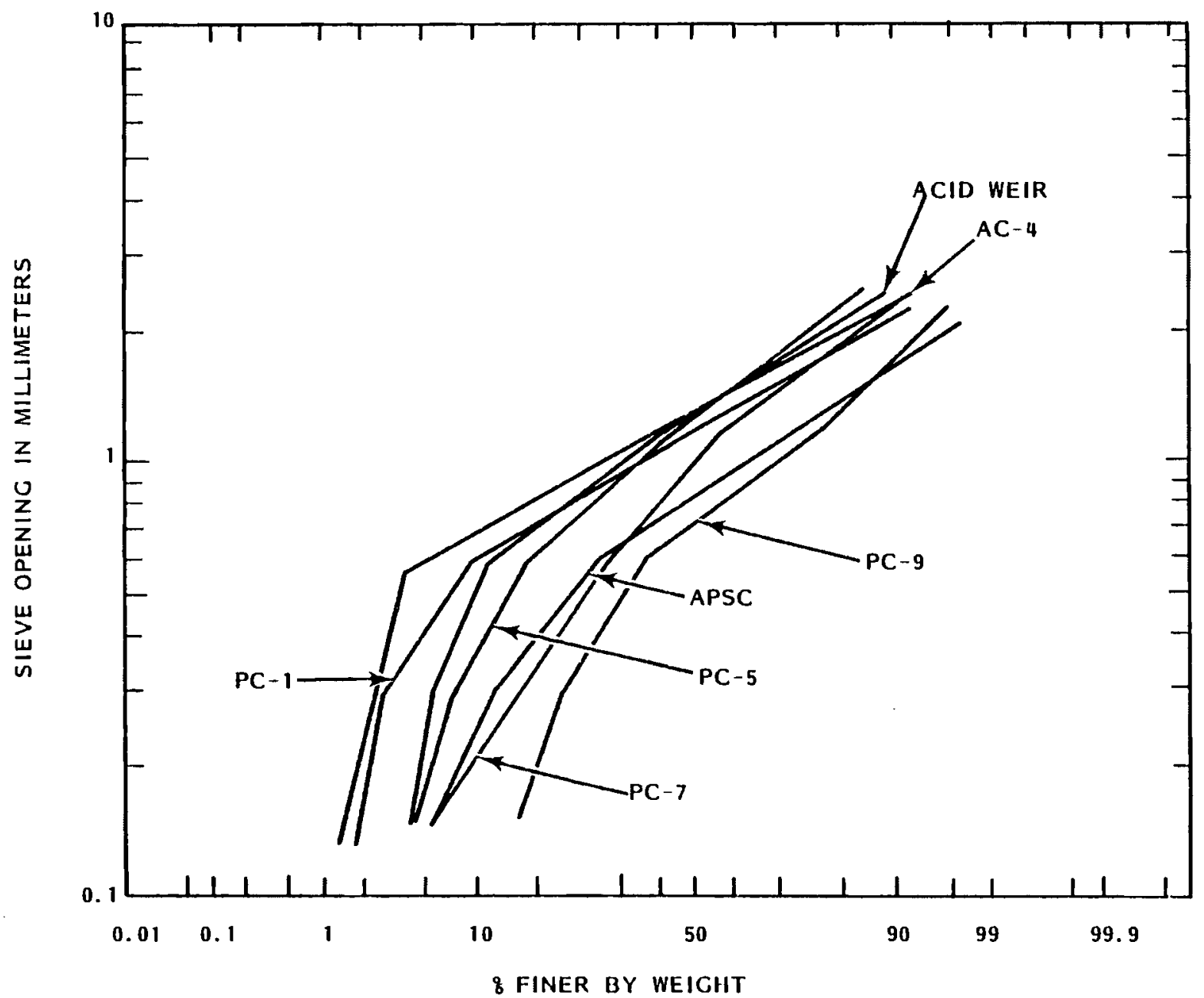

FIGURE 4.6. Sediment-Size Uistribution of Channel Sediments from Acid and Pueblo Canyons. [See Figure 4.5 for station (e.g., $P(-7, P C-9$, etc.) locations.j

Radionuclide Distributions

Some data exists regarding the distribution of radionuclides in UP-LA and A-P Canyons. The bulk of the radionuclide activity is associated more with the larger-sized sediment particles than with the finer sediment particles. This is because the larger-sized particles are much more abundant than the finer particles, even though the finer ones have a greater affinity for contaminants. The ${ }^{239} \mathrm{Pu}$ concentrations are above background levels in Acid, iniddle and lower 


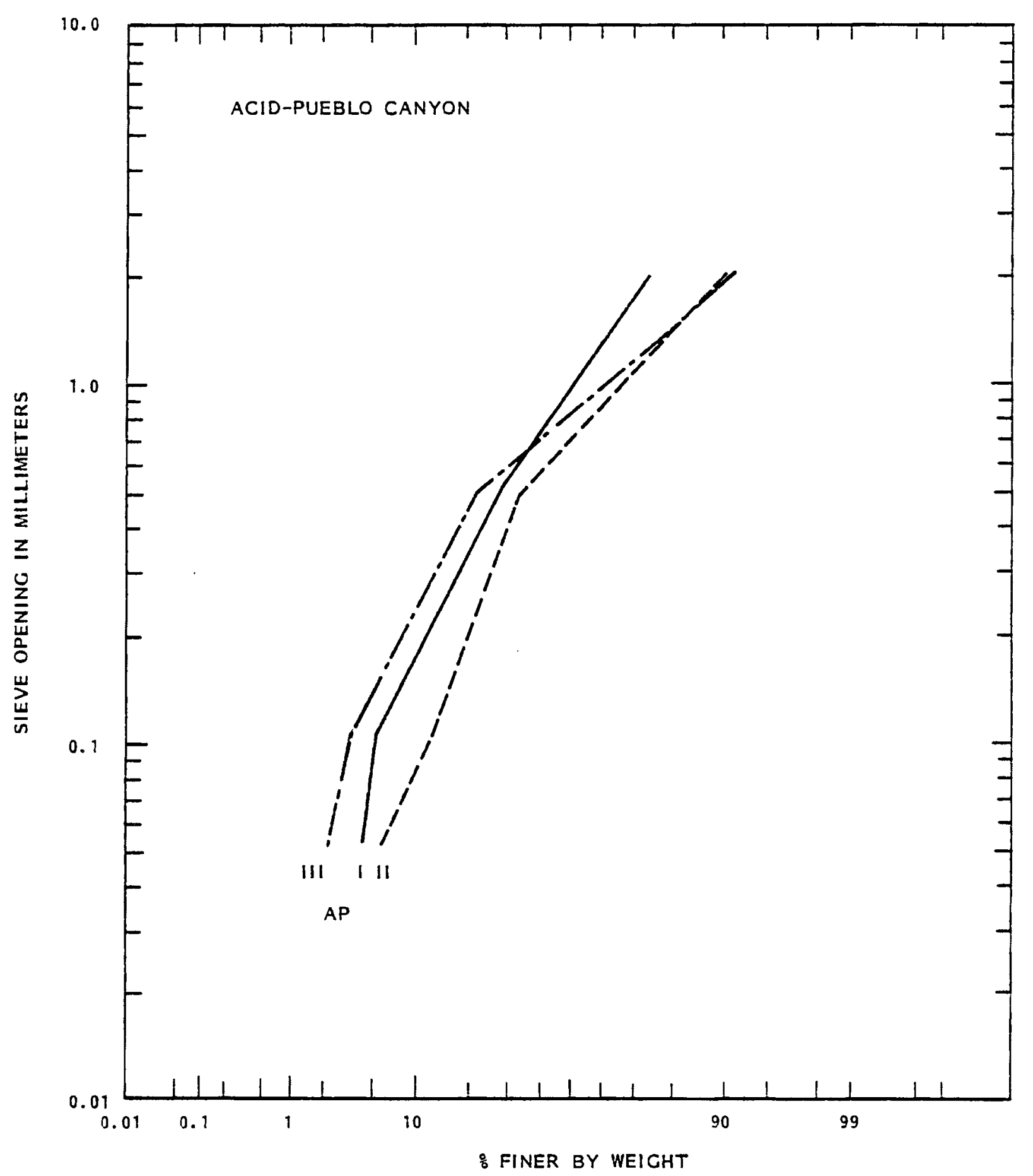

FIGURE 4.7. Sediment-Size Distribution of Channel Sediments from Acid-Pueblo Canyon. [See Figure 4.5 for station (e.g., AP-I, AP-II, etc.) locations]. 
TABLE 4.4. Particle-Size vistribution of Channel Sedinents from DP and Los Alamos Canyons (LANL 1981)

\begin{tabular}{|c|c|c|c|c|c|c|c|c|c|c|c|}
\hline \multirow[b]{2}{*}{ Classification } & \multirow{2}{*}{\multicolumn{2}{|c|}{$\begin{array}{c}\text { Size Range } \\
(\mathrm{mm})\end{array}$}} & \multicolumn{9}{|c|}{ Distribution (\% by Weight) } \\
\hline & & & $\frac{\mathrm{DP}}{\mathrm{DPS}-1}$ & $\frac{\text { anyon }}{\text { DPS-4 }}$ & $\frac{\text { Upper }}{\mathrm{LAO-C}}$ & $\frac{\operatorname{Los} A}{\operatorname{LAO}-1}$ & $\frac{17 \text { amos } C}{L A O-3}$ & $\frac{\text { anyon }}{\mathrm{L} \tilde{A} \mathrm{~S} C}$ & $\frac{\operatorname{Los} A}{\operatorname{LAS}-3}$ & $\begin{array}{l}\text { Lower } \\
\frac{\text { amos Co }}{\text { LAS-4 }}\end{array}$ & $\frac{n y o n}{\text { LAS-7 }}$ \\
\hline anules & 60 to & 3.960 & 8.0 & 4.0 & 16.5 & $<0.5$ & 0.5 & 4.5 & 0.5 & 1.0 & 10.5 \\
\hline and & 0 to & & 48.5 & & & & & & & & \\
\hline Coarse sand & 0.589 to & 1.1 & 29.0 & 36.0 & 32.0 & 53.0 & 40.0 & 33.0 & 25.0 & 47.0 & 38.5 \\
\hline$\pi$ sand & 5 to & 0.5 & & & & 18 & & & & & 11.5 \\
\hline & 147 to & 0.2 & 3. & 4 & 2.0 & 4. & 11 & 10 & 21 & & 4.0 \\
\hline fine sand & 0.074 to & 0.1 & 1. & 1. & 0. & 0. & 4 & & & & 2.0 \\
\hline Silt and clay & & $<0.074$ & 2.0 & 1.5 & 0.5 & 0.5 & 7.5 & 3.0 & 3.5 & 4.0 & 4.0 \\
\hline
\end{tabular}

TABLE 4.5. Particle-Size Uistribution of Channel Sediments
from UP-LoS Alamos Canyon

Distribution (\% by weight)

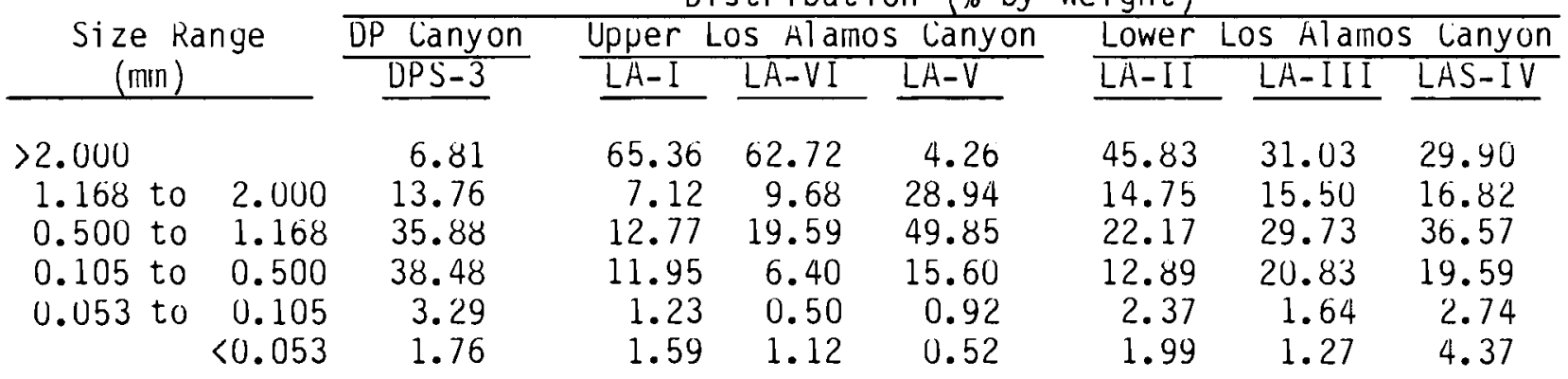

(a) Samples taken a 17.8 to $25.4 \mathrm{~cm}$ from top by staff at the Los Alamos National Laboratory.

TABLE 4.6. Average Particle-Size vistribution of Weathered Tuff and Channel and Suspended Sediments in UP Canyon (Purtymun 1974b) (a)

\begin{tabular}{|c|c|c|c|c|}
\hline \multirow[b]{2}{*}{ Classification } & \multirow[b]{2}{*}{$\begin{array}{c}\text { Size Range } \\
(\mathrm{mm})\end{array}$} & \multicolumn{3}{|c|}{ Distribution (\% by Weight) } \\
\hline & & $\begin{array}{c}\text { Weathered } \\
\text { Tuff }\end{array}$ & $\begin{array}{l}\text { Channel } \\
\text { Sediment }\end{array}$ & $\begin{array}{l}\text { Suspended } \\
\text { Sediment }\end{array}$ \\
\hline Very fine gravel & 2.000 to 4.000 & 1 & 5 & 0 \\
\hline Very coarse sand & 1.000 to 2.000 & 10 & 37 & 6 \\
\hline Coarse sand & 0.500 to 1.000 & 16 & 39 & 14 \\
\hline Medium sand & 0.250 to 0.500 & 12 & 12 & 13 \\
\hline Fine sand & 0.125 to 0.250 & 10 & 5 & 15 \\
\hline Very fine sand & 0.062 to 0.125 & 9 & 0.5 & 17 \\
\hline Silt and clay & $<0.062$ & 42 & 1.5 & 35 \\
\hline
\end{tabular}

(a) Average of five analyses. 
Pueblo, and lower Los Alamos Canyons with the nighest levels at the outfall (waste disposal location) in Acid Canyon. Bed contaminant levels at various locations have been recorded for a number of years (LANL 1981). Due to the nature of this study, the most recent information regaraing contaminant levels were used in the simulation process. This information is presented in Tables 4.7, 4.8, and 4.9. Table 4.7 presents measured bed contanination levels of $239 \mathrm{Pu}$ in Acid, Pueblo, and lower Los Alamos Canyons. Table 4.8 presents the measured bed contamination levels of $239 \mathrm{pu}$ in upper Los Alamos Canyon, while Table 4.9 presents the measured bed contamination levels of $239 \mathrm{Pu}$ in Acid Canyon. The distances provided in these tables are estimates based on station locations using maps of the Los Alamos site. In general, the particulate concentrations decreased with an increase in distance from the outfall.

TABLE 4.7. Measured bed Contamination Levels of ${ }^{239} \mathrm{Pu}$ in Acid, Pueblo, and Lower Los Alamos Canyons

Distance from Head of
Acid Canyon (m)

Acid Canyon

$0-350$

590

670

Pueblo Canyon

900

4,470

6,970

8,070

10,400

Lower Los Alamos Canyon

10,600

12,700

14,000

15,320

17,720
Average Contaminant Concentrations in the Bed $(\mathrm{pCi} / \mathrm{g})$

a) Largest value used, when more than one provided.

(b) Environmental Service Group (1980).

(c) Environmental Service liroup (1979).

(d) Environmental Service Group (1978).

(e) See Table 4.9. 


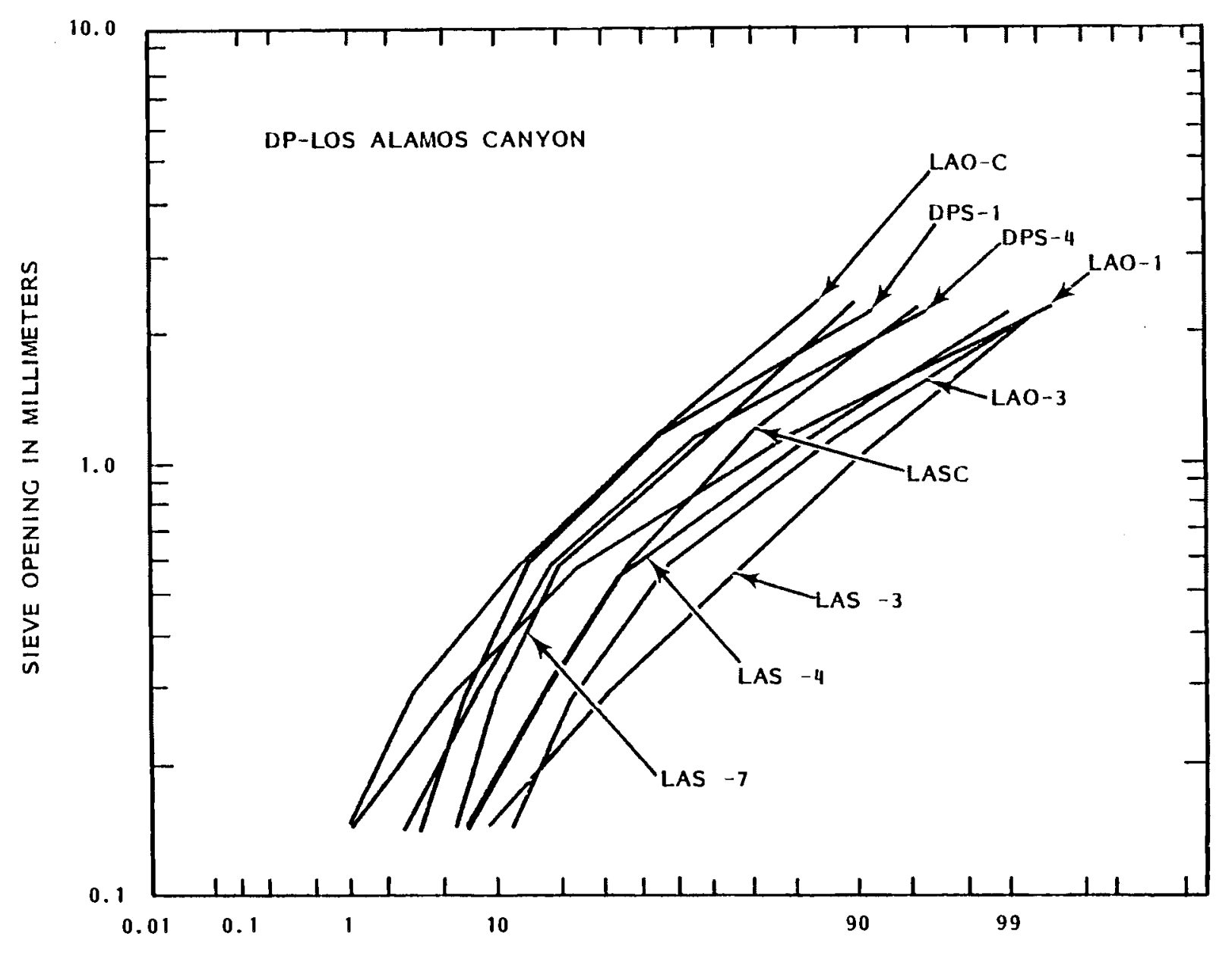

₹ FINER BY WEIGHT

\section{FIGURE 4.8. Sediment-Size vistribution of Channel Sediments from DP and Los Alamos Canyons. [See Figure 4.5 for station (e.g., LAO-3, LAS-3, etc.) locations.]}

The activity level of the radionuclides is generally confined to the top $30 \mathrm{~cm}$ of the bed. Table 4.10 presents the vertical distribution of ${ }^{239} \mathrm{Pu}$ attached to bed sediments at various locations in A-P Canyon, while Table 4.11 presents the vertical distribution of ${ }^{239} \mathrm{Pu}$ attached to bed sediments at various locations in UP-LA Canyon. In general, higher ${ }^{239} \mathrm{Pu}$ concentrations 


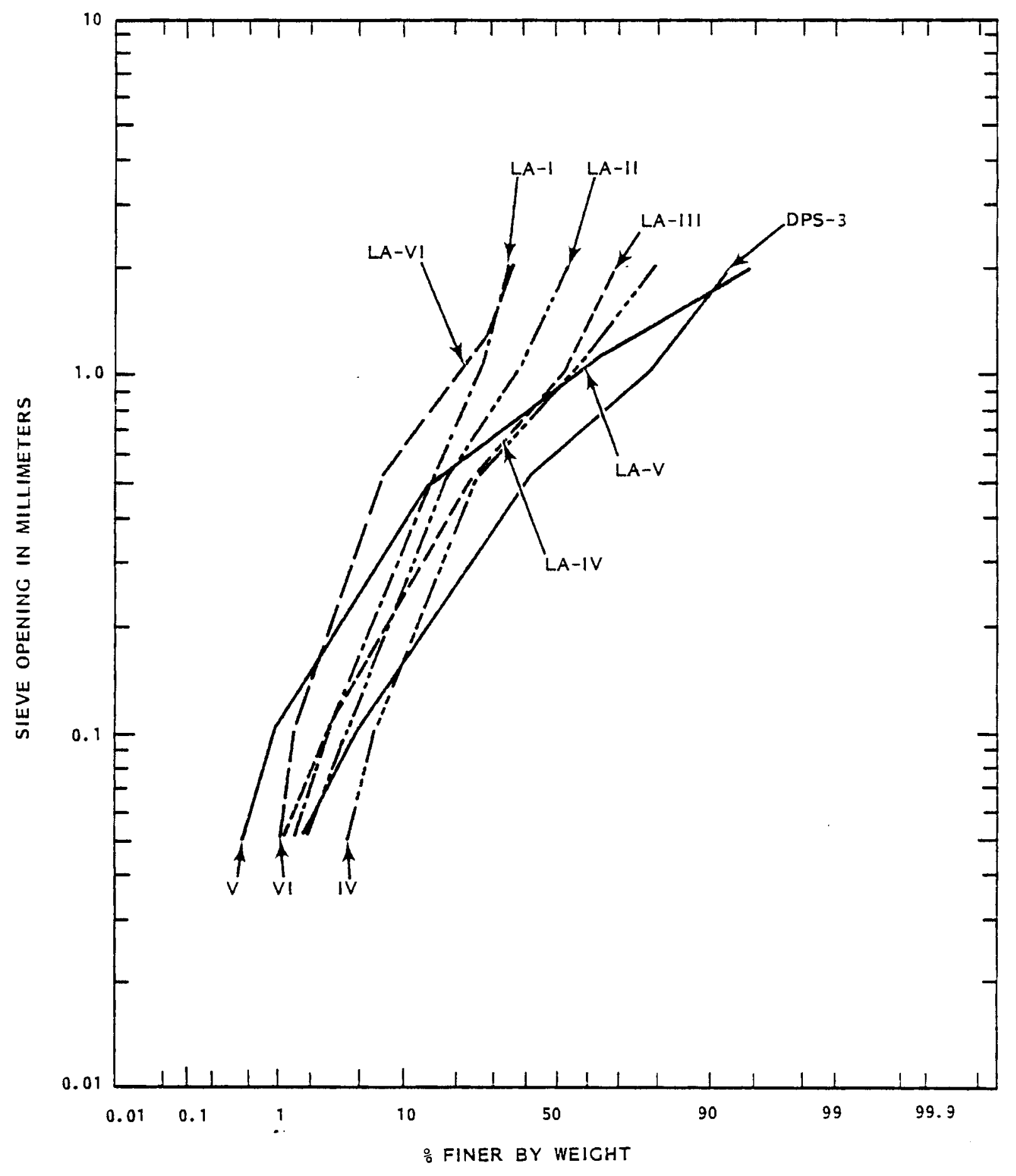

FIGURE 4.9. Sediment-Size Distributions of Channel Sediments from DP-Los Alamos Canyon. [See Figure 4.5 for station (e.g., LA-1, LA-II, LA-III, etc.) locations.] 


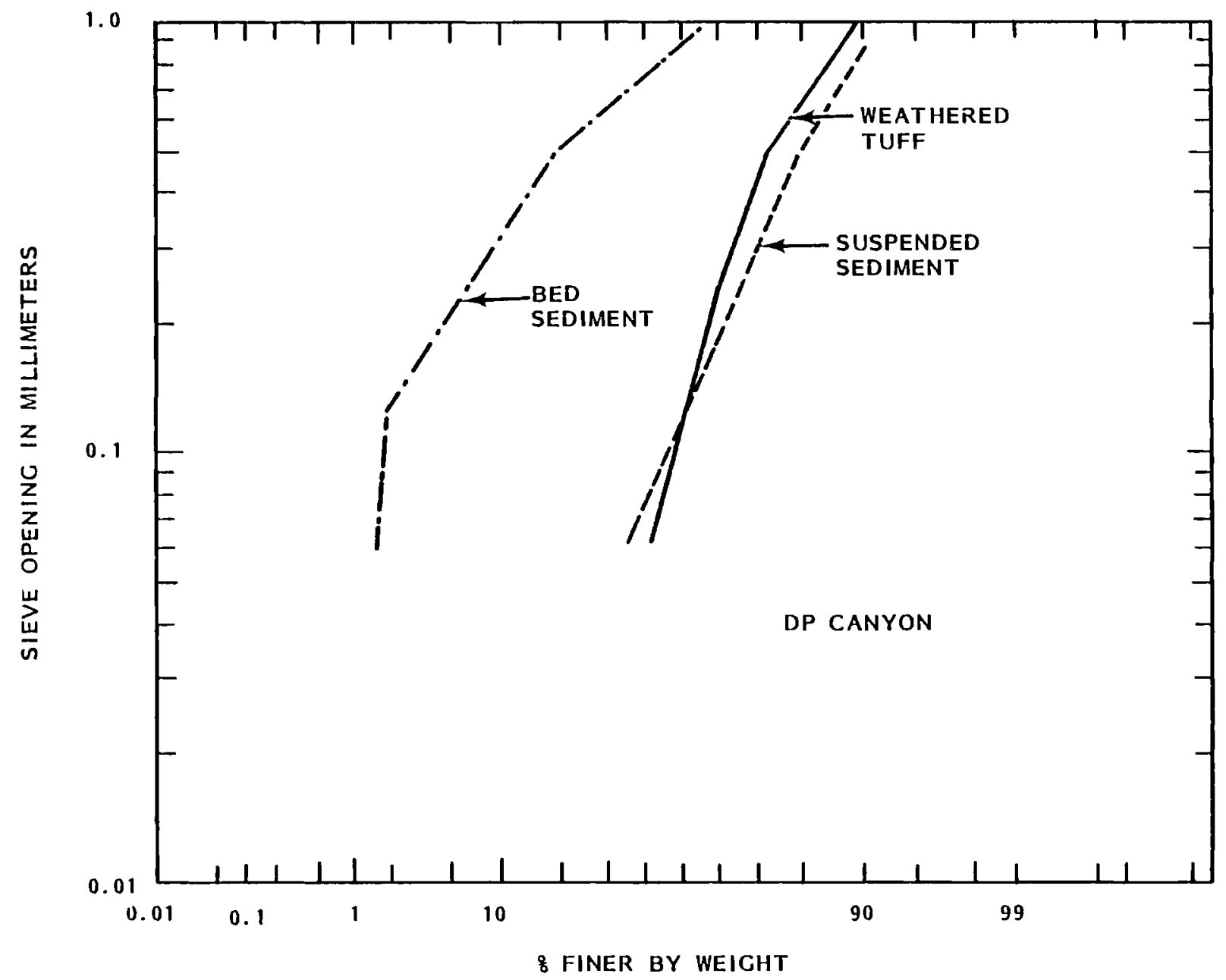

FIGURE 4.10. Average Sediment-Size vistribution of weathered Tuff and Channel and Suspended Sedinents in DP Canyon

appear to be located below the top $2.5 \mathrm{~cm}$ of soil, even though the vertical variation does not follow any specific trends. In addition, the higher concentrations below the surface were vertically averaged with the lower concentrations. This insures higher sediment-contaminant entrainment during flow events. These results are presented in the last column of Tables 4.10 and 4.11. It should be noted, however, that updated data pertaining to contaminant levels at locations greater than $320 \mathrm{~m}$ downstream of the outfalls have superceded the values presented in these tables. 
TABLE 4.8. Measured Bed Contamination Levels of $239 \mathrm{Pu}$ in upper Los Alamos Canyon

\begin{tabular}{|c|c|}
\hline $\begin{array}{l}\text { Distance from Reservoir } \\
\text { in Los Alamos Canyon (m) }\end{array}$ & $\begin{array}{l}\text { Average Contaminant Concentrations } \\
\text { in the Bed }(\mathrm{pC} i / \mathrm{g})\end{array}$ \\
\hline 0 & $0.005^{(b)}$ \\
\hline 3,555 & $0.001(a)$ \\
\hline 7,325 & $0.910(b)$ \\
\hline 9,400 & $0.217^{(c)}$ \\
\hline 10,800 & $0.616(\mathrm{c})$ \\
\hline 14,400 & $0.363^{(c)}$ \\
\hline
\end{tabular} (a) Value is less than the error bound and less than
background levels.
(b) Environmental Service Group (1980).
(c) Environmental Service Group (1979).

TABLE 4.9. Measured Bed Contamination Levels of ${ }^{239} \mathrm{Pu}$ in Acid Canyon

\begin{tabular}{|c|c|c|}
\hline $\begin{array}{l}\text { Distance from Head of } \\
\text { Acid Canyon }(\mathrm{m})\end{array}$ & $\begin{array}{c}\text { Vertically Averaged } \\
\text { Contaminant Concentrations } \\
\text { in the Bed (pCi/g) }\end{array}$ & $\begin{array}{l}\text { Weighted } \\
\text { Concentration } \\
(\mathrm{pCi} / \mathrm{g})\end{array}$ \\
\hline 0 & $21,000 .(a, b)$ & \multirow{7}{*}{962.319} \\
\hline 30 & $11.213(\mathrm{c})$ & \\
\hline 50 & $16.800(c)$ & \\
\hline 70 & $20.577^{(c)}$ & \\
\hline 110 & $299.717(c)$ & \\
\hline 190 & $14.300(c)$ & \\
\hline 350 & $10.987(c)$ & \\
\hline
\end{tabular}

(a) Not found in channel, but in nearby rock.

(b) Figure 15 from LANL (1981).

(c) Table A-XLI from LANL (1981). 
TABLE 4.10. Plutonium in Sediments from Acid-Pueblo Canyon Special Study, 1973 (LANL 1981) (analyses in $\mathrm{pCi} / \mathrm{g}$ )

\begin{tabular}{|c|c|c|c|c|c|}
\hline \multirow[b]{2}{*}{ Location (a) } & \multicolumn{4}{|c|}{ Deptn of Sediment in $\mathrm{cm}$} & \multirow[b]{2}{*}{$\begin{array}{l}\text { Weighted Average } \\
\text { Based on Deptn }\end{array}$} \\
\hline & 0 to 2.5 & 2.5 to 7.5 & 7.5 to 12.5 & $\geq 12.5^{(b)}$ & \\
\hline Control & 0.122 & 0.137 & $-\infty$ & -- & \\
\hline Outfall & 16.6 & 8.52 & --- & --- & 11.2 \\
\hline 20 & 16.8 & -- & -- & -- & 16.8 \\
\hline 40 & 5.78 & 8.72 & 11.4 & 28.7 & 20.6 \\
\hline 80 & 6.21 & 6.60 & 21.1 & 505 & 300 \\
\hline 160 & 8.61 & 10.1 & --- & 20.4 & 14.3 \\
\hline 320 & 8.28 & 7.92 & 10.8 & 12.3 & 11.0 \\
\hline 640 & 7.86 & 12.4 & 10.4 & 19.1 & 15.6 \\
\hline 2,560 & 36.6 & 369 & 2250 & $-\infty$ & 1055 \\
\hline 5,120 & 1.39 & -- & 0.617 & 1.65 & 1.42 \\
\hline 10,240 & 0.40 & 0.518 & 0.435 & $-\infty$ & 0.46 \\
\hline
\end{tabular}

(a) Meters below outfall.

(b) Remainder varied from $12.5 \mathrm{~cm}$ to $30 \mathrm{~cm}$.

TABLE 4.11. Plutonium in Sediments from DP-Los Alamos Canyon Special Study, 1973 (LANL 1981) (analyses in pCi/g)

\begin{tabular}{|c|c|c|c|c|c|}
\hline \multirow[b]{2}{*}{ Location (a) } & \multicolumn{4}{|c|}{ Depth of Sediment in $\mathrm{cm}$} & \multirow[b]{2}{*}{$\begin{array}{l}\text { Weighted Average } \\
\text { Based on Depth }\end{array}$} \\
\hline & 0 to 2.5 & 2.5 to 7.5 & 7.5 to 12.5 & $>12.5^{(b)}$ & \\
\hline Control & 0.036 & 0.036 & 0.044 & 0.051 & \\
\hline Outfall & 957 & 1640 & $\ldots$ & --- & 1412 \\
\hline 20 & 24.8 & 16.4 & 2.63 & -- & 12.6 \\
\hline 40 & 18.2 & $\ldots$ & 11.4 & 0.488 & 4.4 \\
\hline 80 & --- & 10.4 & 1.87 & 0.831 & 2.8 \\
\hline 160 & 0.332 & 2.25 & 0.369 & 0.328 & 0.66 \\
\hline 320 & 0.196 & 0.252 & 0.225 & 2.34 & 1.46 \\
\hline 640 & 0.344 & 0.481 & 0.445 & -- & 0.439 \\
\hline 1,280 & 0.864 & 0.878 & 0.644 & 1.78 & 1.36 \\
\hline 2,560 & 0.183 & 0.090 & 0.114 & --- & 0.118 \\
\hline 5,120 & 0.599 & 0.186 & --- & --- & 0.324 \\
\hline
\end{tabular}

(a) Meters below outfall.

(b) Remainder varied from $12.5 \mathrm{~cm}$ to $30 \mathrm{~cm}$. 
LANL (1981) also presents estimated ${ }^{239} \mathrm{Pu}$ bed concentrations and inventories distributed spatially along A-P Canyon. These results are presented in Figures 4.11 and 4.12, respectively. Figure 4.11 indicates that banks and inactive channel areas tend to have higher concentrations than the active channel. This is expected since intermittent runoff events inundate these areas less frequently, thereby resuspending less of the contaninated sediment. It should be noted that the extremely large concentration $(21,000+$ 49,000 $\mathrm{p}(\mathrm{i} / \mathrm{g})$ depicted at the treatment plant in Figure 4.11 is not associated with the channel proper but with sediment within the nearby Bandelier tuff.

Figure 4.12 indicates that the majority of the ${ }^{239} \mathrm{Pu}$ is located in lower Pueblo Canyon (67\%). This is expected because at this location the channel widens and the gradient decreases reducing the flow velocity and depositing contaminated suspended sediment (LANL 1981). The ${ }^{239} \mathrm{Pu}$ inventories were estimated as a product of the averaged concentrations in the channels and banks of each segment and the estimated mass of affected sediments and soils derived from average measured dimensions and density. Figure 4.12 also indicates the degree to which sediments in the inactive channel and banks are contaminated relative to the sediments in the active channel.

\section{Distribution of Contamination Within the Channel Bed}

Acid Canyon. Even though the majority of ${ }^{239} \mathrm{Pu}$ inventory is estimated to be in lower Pueblo Canyon (Figure 4.12) a contaminant level of possible significance may exist in Acid Canyon at the outfall. This information is presented in Figure 4.11 in which the $239 \mathrm{Pu}$ concentration at the outfall was estimated as $21,000+49,000 \mathrm{pCi} / \mathrm{g}$. This contaminated region by personal inspection is categorized as being mainly composed of nonerodible rock with the subsurface environ inaccessible with the surface environ and with the area appearing unweathered. LANL (1981) notes that the contaminated area has a maximum areal extent of $0.15 \mathrm{~m}$ in depth, $30 \mathrm{~m}$ in length, and 0.30 to $0.75 \mathrm{~m}$ in width. This size area represents a very small fraction of the Acid Canyon catchment $\left(\sim 1.36 \times 10^{-3} \%\right.$ of the total area comprising Acid Canyon). Since this contaminated area is at the head of Acid Canyon and since it represents a very small fraction of the total Acid Canyon catchment, very little precipitationgenerated runoff flows over this region. We did not want to underestimate the 


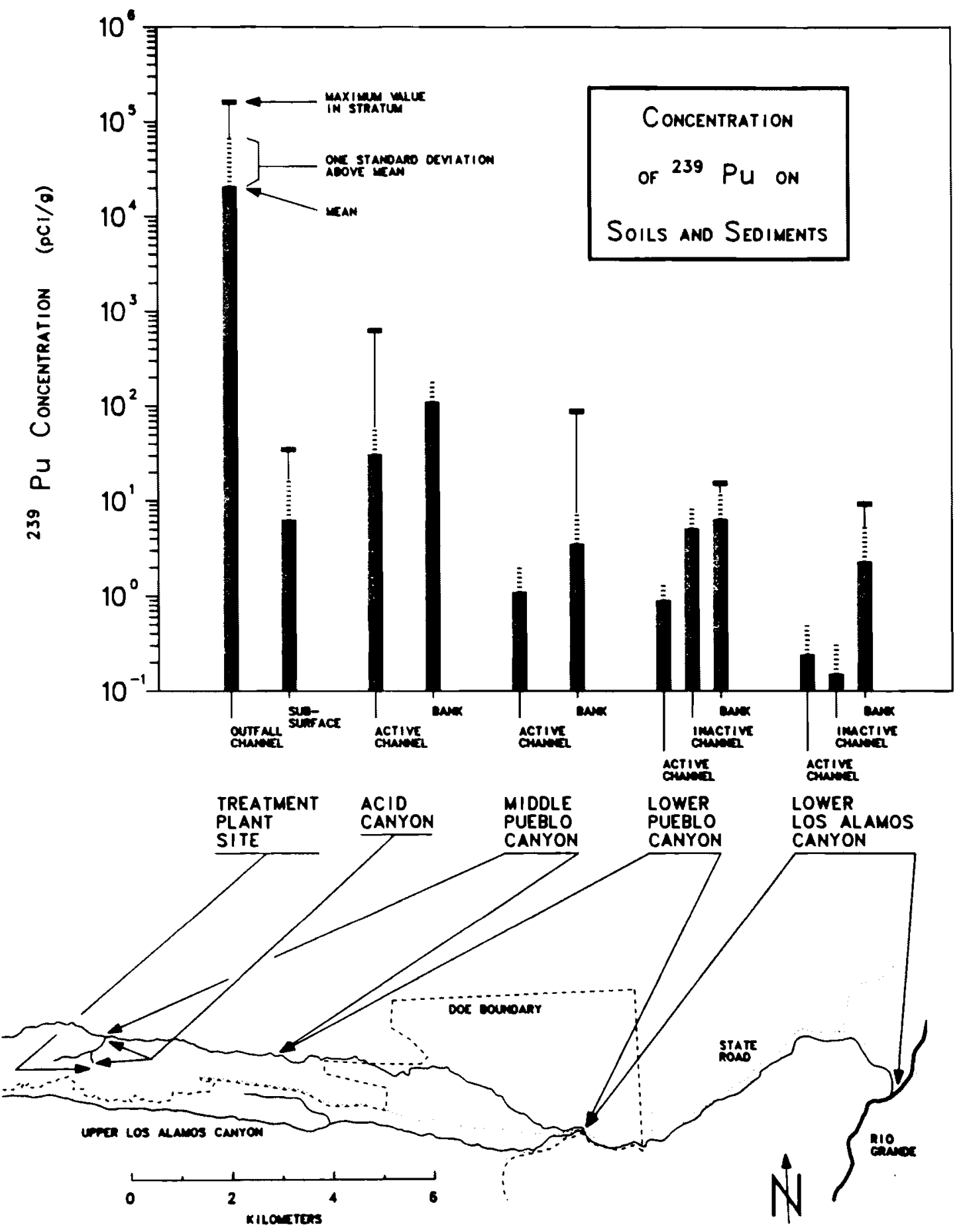

FIGURE 4.11. Concentration of ${ }^{239} \mathrm{Pu}$ on Soils and Sediments by Location (LANL 1981) 


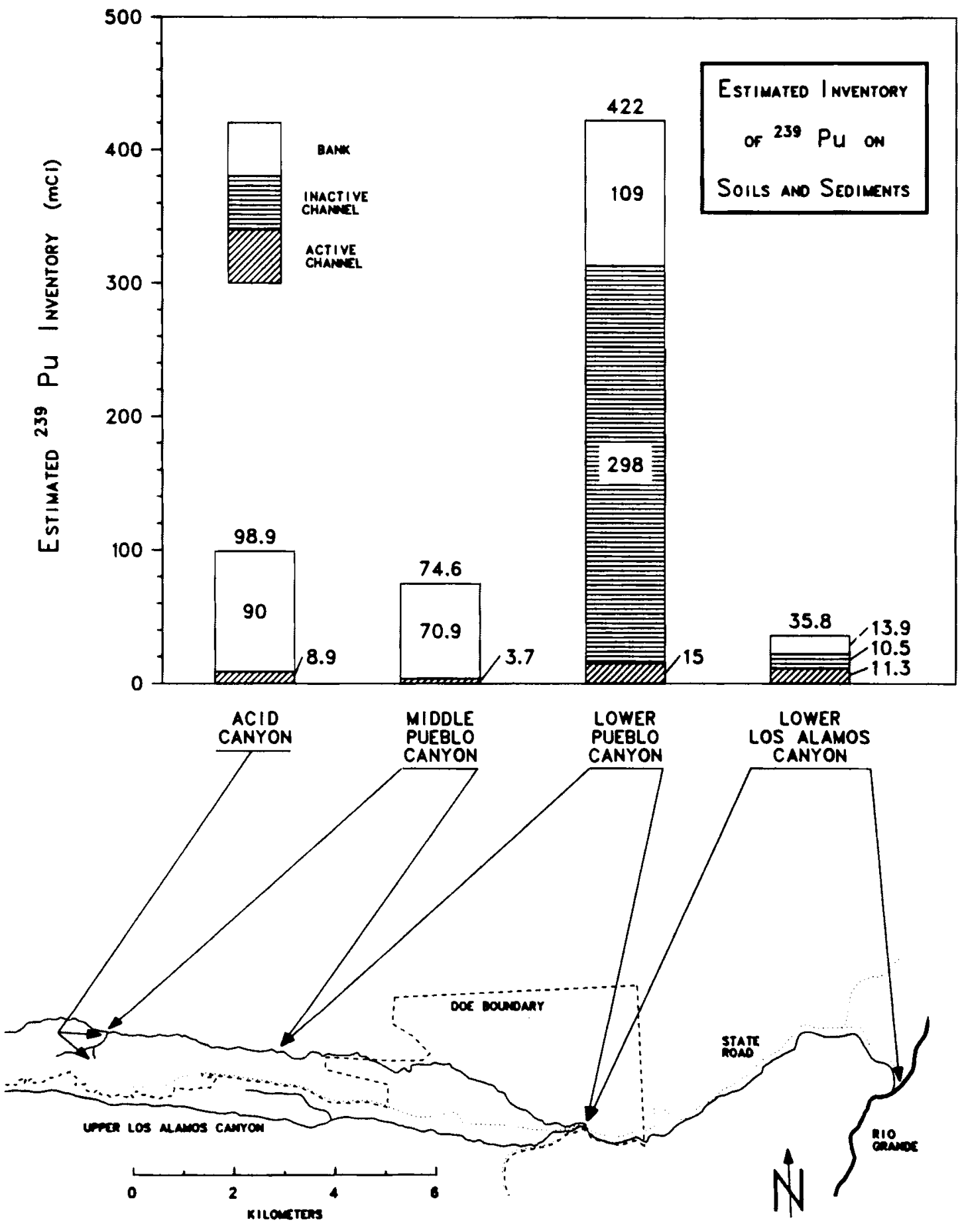

FIGURE 4.12. Estimated Inventory of ${ }^{239} \mathrm{Pu}$ on Soils and Sediments by Location (LANL 1981) 
possible contamination from this region, since the ${ }^{239} \mathrm{Pu}$ concentrations were so high. The error associated with the ${ }^{239} \mathrm{Pu}$ concentration is significantly larger than the concentration itself. This is very difficult to ignore and difficult to model. The contaminated outfall area was therefore modeled as a channel section in the modeling scenario. By representing this area as a channel segment, overland flow is concentrated in the "channel segment" resulting in a higher possibility of entrainment of the contaminated bed sediments. The $21,000 \mathrm{pCi} / \mathrm{g}$ contamination concentration was assumed to be uniformly distributed vertically in the bed. It was uniformly distributed throughout the top $30 \mathrm{~cm}$ of soil as opposed to the top $15 \mathrm{~cm}$ as suggested by LANL (1981). In addition, the $21,000 \mathrm{pCi} / \mathrm{g}$ was distributed by particle size according to Equations (4.21) through (4.24). Because of this distribution, the silt and clay particles have concentrations much higher than that of sand (Section 4.4.1). (ilay and silt particles have a better chance of being carried downstream when entrained than do sand particles. In addition, the outfall channel segment ( $30 \mathrm{~m}$ in length) was combined with the next downstream channel segment (total length equaling $350 \mathrm{~m}$ ) with the contamination being averaged over this length. This was done in order to have a larger portion of the flow from the watershed drain into this channel segment, which increases the possibility of contaminated sediment being entrained into the flow. The effect on contaminant concentrations of combining these segments is presented in Table 4.9 .

In the case of "large" flood events, the scenario presented above may be unrealistic. Entrainment of the contaminated sediments from the first channel section may dominate the contaminant migration scenario to the extent that ${ }^{239} \mathrm{Pu}$ located in other portions of the reach become insignificant in impacting downstream areas. In the case where erosion from the first channel section dominates the contaminant migration phenomena, it should be modeled as an overland section to best simulate the actual phenomena occurring. This was unnecessary as this channel portion experienced aggradation. It was originally modeled as a channel section instead of an overland area because if under these circumstances no major impact occurs downstream, then none would be expected to occur if modeled as an overland segment. 
LANL (1981) notes that approximately $170 \mathrm{mC} i$ of contamination were released into Acid Canyon. Figure 4.12 suggests, though, that $631 \mathrm{mCi}$ were released and that of this amount only approximately 16 remain. By assuming the contamination level as presented in Table 4.9, the total inventory for this one segment alone has a magnitude 67 of the total observed release (114 mCi) into Acid Canyon and 18 of the suggested release into Acid Canyon (Figure 4.12).

It should be noted that the outfall contamination of $21,000+49,000 \mathrm{pci} / \mathrm{g}$ represents the contamination of a very small area. The error bound associated with this contamination is larger than the measured value itself. Care, therefore, should be employed when using this number in computations.

Pueblo-Los Alamos Canyon. Each soil layer comprising the bed equalled $30 \mathrm{~cm}$ in depth with a uniform distribution of contaminant concentrations assumed for the $30 \mathrm{~cm}$ of soil. Thirty centimeters was chosen because all documented contaminant concentration levels were within $30 \mathrm{~cm}$ of the surface (LANL 1981). In all soil layers below $30 \mathrm{~cm}$, the bed was assumed to be devoid of all contamination. For more information on bed contaminant levels, refer to Section 4.1 .2 .

Modeling Scenario

In order to analyze the migration and fate of significant quantities of radionuclides, three models have been selected for use in the simulation: ARM, MOUSEEP, and TODAM. ARM and MUDSEEP are used in computing precipitationgenerated flood events overland and instream, respectively, while TODAll simulates the migration and fate of in-stream sediments and radionuclides.

Care must be insured when simulating the precipitation-generated flood events so that the modeling objective is met. If the flood events are too large, the in-stream contaminant concentrations could drop below significant levels due to dilution. In addition, a large flood event could carry the contaminated effluent completely through the Los Alamos site to the Rio Grande where its effects may be insignificant.

If the flood events are too small, a significant amount of radionuclide inventory may not be transported downstream. Because the modeling scenario 
considers seepage of flows out of the channel, a small storm event may be significantly reduced (due to seepage) by decreasing the discharge and depositing contaminated suspended sediments before they are transported from Pueblo Canyon. Lower Pueblo Canyon can be very susceptible to this, due to its shallow gradient and broader cross section. In addition, the flows should be large enough so that the contaminated sediments are entrained. It must be remembered that the bed material is fairly large (coarse to very coarse sand) and some flood events will not move significant amounts of contaminated sediment.

In order to Inaximize the effects of contaminant entrainment upstrearl of the Pueblo-Los Alamos Canyon confluence and minimize the movement of contaminants out of lower Los Alamos Canyon within the San Ildefonso Pueblo, the Acid-Pueblo-lower Los Alamos Canyon area was the only area modeled with no water or sediment included from overland segments in lower Los Alamos Canyon. By not including water and sediment from the overland segments in lower Los Alamos Canyon, the contaminated sediment reaching this area from upstream of the Pueblo-Los Alamos Canyon confluence would have a better chance of being deposited in this region. Including the flow from upper Los Alamos Canyon would have increased the size of the flood event substantially below the contluence of Pueblo-upper Los Alamos Canyon (yiven equal flood recurrence intervals for Pueblo and upper Los Alamos Canyons, see Section 4.1.5) reducing the possibility of deposition of contaminated sediments in lower Los Alamos Canyon. Only 16 of the total amount of ${ }^{239} \mathrm{Pu}$ released into the environment at the Los Alamos site was released into UP Canyon. LANL (1981) further reported that "...interpretations of the data from other studies...suggest that at least 75 of the releases (into) UP Canyon have been transported into lower Los Alamos Canyon." This suggests that only 4 of the total amount of $239 \mathrm{pu}$ released at the Los Alamos site remains in DP or upper Los Alamos Canyon. Since the majority of contaminant inventory is located in Acid-Pueblo Canyon, the movement of contaminants from upper Los Alamos Canyon would probably be well below that of Pueblo Canyon, thereby diluting the contamination from Pueblo Canyon. Again, this reduces the possibility of depositing the nighest possible particulate concentrations into the bed in lower Los Alamos Canyon. Acid-Pueblo Canyon, therefore, represents the critical pathway in the modeling scenario. 
A precipitation-generated flood event with a recurrence interval of 50 years was analyzed on Acid-Pueblo-lower Los Alamos Canyon. Modeling a flood event with a return period of less than 50 years would accomplish little, since the flows would probably not be high enough to transport significant quantities of $239 \mathrm{Pu}$ downstream. It should be noted that little precipitation or flood data exist on Acid-Pueblo Canyon and that the recurrence interval of actual flood events occurring in this area is unknown. For more information regarding the results of the modeling scenario, refer to Sections $4.2,4.3$, and 4.4 .

A small portion of the San Ildefonso Pueblo exists downstream of the confluence of Los Alamos and Bayo Canyons. This section of the reach was not modeled for several reasons. Bayo Canyon is a watershed approximately one-half the size of Pueblo Canyon (refer to Table 4.1) with flows from the canyon containing no ${ }^{239} \mathrm{Pu}$ contamination. Even though Bayo Canyon is smaller than Pueblo or Los Alamos Canyons, its peak discharges for similar flood recurrence intervals are very nearly the same. Table 4.12 presents return periods for 2$y r, 5-y r, 10-y r, 25-y r$, and 50-yr flood events on Bayo, Pueblo, and upper Los Alamos Canyon as well as the corresponding size of each canyon. By including the water and sediment from upper Los Alamos Canyon, lateral inflow contributions from lower Los Alamos Canyon, and tributory inflow contributions from Bayo Canyon (and Guaje Canyon), the major bulk of contamination originating from Acid-Pueblo Canyon reaching the confluence of Bayo and LoS Alamos Canyons would probably be carried downstream to the Rio Grande. In addition, the added water and sediment (of which most is devoid of contamination) would probably dilute the contamination in stream in the modeling simulation, since all contamination is uniformly distributed within the water column and with the entrained and deposited sediments. Lastly, very little data exists pertaining to Bayo Canyon. This, in itself, could preclude modeling the region, since the amount of data required by the three complex codes employed in the simulation scenario is rather extensive. Fulfilling the needs of these codes with the necessary and pertinent data at this time appears unlikely. The results from the three codes are only as good as the data they receive. 
TABLE 4.12. Watershed Size, Flood Frequency, and Corresponding Maximuri Discharge for Bayo, Acid-Pueblo, and DP-Upper Los Alamos Canyons (Wheeler 1979)

\begin{tabular}{|c|c|c|c|c|c|c|}
\hline \multirow[b]{2}{*}{ Watershed } & \multirow{2}{*}{$\begin{array}{c}\text { Watershed } \\
\text { Areą } \\
\left(\mathrm{km}^{2}\right) \\
\end{array}$} & \multicolumn{5}{|c|}{ Flood Frequency } \\
\hline & & $2-y r$ & $5-y r$ & $10-y r$ & $25-y r$ & $50-y r$ \\
\hline Bayo & 9.8 & $2.4 \mathrm{~m}^{3} / \mathrm{s}$ & $6.1 \mathrm{~m}^{3} / \mathrm{s}$ & $8.5 \mathrm{~m}^{3} / \mathrm{s}$ & $17.0 \mathrm{~m}^{3} / \mathrm{s}$ & $19.0 \mathrm{~m}^{3} / \mathrm{s}$ \\
\hline $\begin{array}{l}\text { Acid- } \\
\text { Pueblo }\end{array}$ & 22.3 & $3.1 \mathrm{~m}^{3} / \mathrm{s}$ & $7.1 \mathrm{~m}^{3} / \mathrm{s}$ & $10.0 \mathrm{~m}^{3} / \mathrm{s}$ & $17.0 \mathrm{ril}^{3} / \mathrm{s}$ & $21.0 \mathrm{~m}^{3} / \mathrm{s}$ \\
\hline $\begin{array}{l}\text { Upper } \\
\text { Los Alamos }\end{array}$ & 27.5 & $3.0 \mathrm{~m}^{3} / \mathrm{s}$ & $6.8 \mathrm{~m}^{3} / \mathrm{s}$ & $11.0 \mathrm{~m}^{3} / \mathrm{s}$ & $16.0 \mathrm{~m}^{3} / \mathrm{s}$ & $20.0 \mathrm{~m}^{3} / \mathrm{s}$ \\
\hline
\end{tabular}

(a) Refer to Table 4.1.

\subsubsection{Pathway and Model Selection}

Pathway Selection

A preliminary analysis of natural phenomena, which could result in an increase of radionuclides downstream of the Pueblo-Los Alamos Canyon confluence, showed that the key pathways requiring detailed evaluation were the overland and in-stream pathways. Precipitation and snowmelt events transport water and sediment overland to the in-stream channel systern. Unce in the channel, water, sediment, and radionuclides can migrate downgradient through a continuous process of in-stream sediment transport, deposition, and resuspension. Because most of the contamination exists in the bed of the stream channels, the dynamic processes describing the nistory of the bed, distribution of sediments and radionuclides in the bed, aggradation, and degradation should be included in any modeling scenario. The types of models included for the modeling scenario are a) an overland runoff-soil erosioncontaminant transport model, b) an in-stream hydrodynamic model, and c) an instream sediment-radionuclide transport model. The first and third models should include algorithms for computing the migration of radionuclides in their particulate (adsorbed to sediment) and dissolved states. 
Model Selection

The primary criteria for initial selection of models were the availability of state-of-the-art modeling capabilities in each of the areas mentioned above and the adequacy of the models in describing the unique characteristics of the sites. Acid-Pueblo and DP-Los Alamos Canyons represent a unique region, which calls for models with certain unique features. This region's channels are generally dry between storms. The channels may be described as ditch-like, with high representative roughness values as opposed to the more traditional river bed. Low-flow discharges and deptns are typical in the region. Channel slopes are also quite high $(>1 \%)$.

PNL has been active for a number of years in the area of overland and instream contaminant transport (e.g., Unishi et al. 1981, Parkhurst et al. 1981, and Onishi, whelan, and Skaggs 1982). They have developed and are now refining models to predict radionuclide migration in rivers, lakes, estuaries, and oceans. Three codes which PNL has used in the past, have been selected for the modeling scenario: ARM (Agricultural Runoff Manayement Model), MODSEEP (Modified Uiffusion Wave with Seepage Model), and TODAM (Transient UneDimensional Degradation and Migration Model).

Uverland Hydrodynamic and Contaminant Transport Model (ARM)

Processes controlling runoff, soil erosion, and radionuclide transport on the land surface are continuous in nature even though radionuclide migration may take place only during runoff-producing storm events. Hence, a continuous simulation hydrologic model is appropriate for this study in order to simulate processes occurring between storms which influence soil moisture content and radionuclide transport within the soil and thereby affect storm runoff volumes, sediment concentrations, and radionuclide transport during a runoff-producing storm event. It is also important that the model be capable of simulating the transport of both dissolved and particulate (those adsorbed by soil) radionuclides.

The Agricultural Runoff Management (ARM) Model developed by Crawford and Donigian (1973) to simulate pesticide migration and fate was selected for use in this study. ARM simulates runoff (including snow accumulation and melt), sediment, pesticides, and nutrient contributions to stream channels from both 
surface and subsurface sources. The hydrologic components of AKM have been successfully tested on nuinerous watersheds across the country (Donigian et al. 1977). The representation of the adsorption-desorption and pesticide degradation elements allows the model to be used for radionuclide transport studies simply by using appropriate values for the coefficients of the equations.

The ARM model is composed of the five major components which continuously simulate the following:

- hydrologic response of watersheds

- soil erosion

- contaminant adsorption and removal

- contaminant decay and degradation

- nutrient transformation and removal.

The last component was not used for this study.

The hydrologic component of ARM simulates the dominant physical processes that act to convert precipitation into runoff (i.e., interception, infiltration, interflow, percolation and evapotranspirtion). ARM also has the capability to simulate the mechanisms of snow accumulation on the land surface and runoff due to melting of the snow pack. The transfer of water between major components of the hydrologic cycle simulated by ARM is not only used to calculate runoff, but is also used in the calculation of soil erosion and the vertical movement of contaminants in the soil profile.

The soil erosion component of ARM simulates sediment loss from the land surface due to both sheet and rill erosion. Soil fines are scoured from the land surface and transported by overland flow. The availability of these inaterials for transport is a function of rainfall impact. The availability of soil fines is also a function of the tillage operations or conservation practices that may have occurred on the watershed.

Contaminants placed in a water-sediment mixture will eventually come to equilibrium, with a certain fraction of the contaminant adsorbed to the sediment materials and the remainder dissolved. The adsorption and removal component of ARM uses a modified Freundlich adsorption/desorption isotherm algorithm to partition the available contaminant between that dissolved in the overland flow and that adsorbed to soil fines being transported by the flow. 
The contamination component of ARM determines the quantity of contaminant available for transport, either by overland flow or by soil erosion, at any time after its application to a watershed. The major processes that act to attenuate contaminants in the soil are degradation and decay, which are lumped together in a simple, first-order decay algorithm.

One of the major limitations of the model is the quantity of historical data required to calibrate model coefficients and parameters. This limitation has been reduced somewhat by the regionalization of many hydrologic parameters. A second limitation is that the ARM model is not formulated to handle the effects of channel processes on runoff and sediment transport. As a result, the model is applicable only to watersheds that are small enouyh that channel processes can be assumed negligible. Modeling various catchment sizes by ARM is limited by climatic and topographic characteristics. Generally, it has been found that ARM is applicable to areas from 2 to $5 \mathrm{~km}^{2}$ (or about 1 to $2 \mathrm{mi}^{2}$ ) (Donigian and Crawford 1976a, 1976b). Because of this limitation, the application of ARM to a large watershed requires the subdivision of the watershed into smaller subcatchments with individual model applications to the smaller subcatchments.

Limitations of the sediment and contaminant transport components of the model relevant to this study include the following:

- The erosion simulation as a function of particle size is not considered. This could have an effect on the adsorption of contaminants to sediment, since small-sized sediments adsorb more contaminant by weight than large-sized sediment.

- The effects of winter freeze/thaw conditions on sediment production and the occurrence of soil detachment and scour by overland flow are not considered in the model. Representation of the soil moisture profile may be too approximate for detailed simulation of the vertical movement and distribution of contaminants.

For more information regarding ARM's methodology, refer to Crawford and Donigian (1973), Donigian and Crawford (1976a, 1976b, 1979), Donigian and Davis 
(1978), Donigian et al. (1977), Uvercash and Davidson (1980), Johanson, Imoff, and Davis (1980), Hydrocomp (1976, 1977), whelan (1982), Brown et al. (1977), and Brandstetter (1977).

In-Stream Hydrodynamic Hodel (MUDSEEP)

The hydrodynamic code used in this application of the MCEA methodology is MUDSEEP (Modified Diffusion Wave with Seepage Model). MUUSEEP is a onedimensional flood routing code which accounts for lateral inflow and seepage though the channel bed. The model is based on a formation developed by cunge (1969) in which wave attenuation is incorporated into a flood propagation model. Ponce and Yevjevich (1978) presented various computational approaches using the Cunge formulation before Colorado State University in 1980 released a coded version called MUSK. MUDSEEP is an upgraded version of the original formulation with the additional capabilities of:

1) flow dependent seepage,

2) time dependent lateral inflow, and

3) dry channel occurrence.

The Saint Venant equations of fluid flow provide the most physically explicit description of one-dimensional open channel flow. In the MODSEEP formulation, the conservation of momentum equation is replaced with a singlevalued depth-discharge rating curve. Theoretically, this model is purely convective, translating flood waves downstream without dissipation. However, the finite difference analog of the continuity equation which MUDSEEP employs is imperfect due to the discrete representation of a continuous phenomenon. MODSEEP simulates naturally occurring flood wave diffusion by precisely matching the truncation error of the finite difference scheme to physicallybased diffusion.

Seepage in MUDSEEP is assumed to be directly proportional to the wetted surface area of the channel. The proportionality constant, which is a flux per unit area, can either be calibrated or supplied from field testing.

MUDSEEP can be used in rivers where storage effects are negligible. The code is particularly effective in steep watersheds and ephemeral streams where dry channel bed conditions occur. 
MUDSEEP is a one-dimensional model and thus is incapable of resolving the lateral or vertical variation of flow parameters. Additionally, the model employs an explicit "marching" solution scheme which progresses from upstream to downstream locations. This unidirectional propagation of information precludes downstream phenomena from effecting changes in the upstream segments. Therefore, downstream controls, e.g., dams, cannot adequately be represented by the model.

Input Requirements at Each Segment

1) Channel geometry

2) Manning's resistance coefficient, $n$

3) Seepage velocity

4) Bed slope

5) Initial and boundary discharge condition

Model Output at Each Segment

1) Vischarge

2) Flow depth

3) Flow area

4) Net channel inflow

5) Volume of discharge

MODSEEP has been designed to address a specific range of river problems. Where applicable, it can provide a simple, user-oriented model at modest expense. The flood routing capability of the model has been demonstrated by published studies (Ponce 1980, Ponce and Yevjevich 1978, and Ponce et al. 1978) in addition to numerical experiments performed at Pacific Northwest Laboratory.

Sediment-Contaminant Transport Model (TODAM)

Onishi et al. (1976) developed the unsteady two-dimensional (longitudinal and vertical) sediment and contaminant transport model SERATRA (SedimentRadionuclide Transport model) as a means of a more realistic prediction of contaminant migration. Onishi, Whelan and Skaggs (1982) simplified SERATRA to the unsteady, one-dimensional sediment and contaminant transport model TODAM (Transient One-Dimensional Degradation and Migration Model). The SERATKA/TUDAM model is a finite element model that predicts the movement of sediment, chemicals and radionuclides. They use general advection-dispersion equations with decay and sink/source terms and appropriate boundary conditions. The 
models consist of the following three submodels, coupled to describe sedimentcontaminant interaction and migration: a) a sediment transport submodel, b) a dissolved-contaminant transport submodel, and c) a particulate-contaminant (contaminant adsorbed by sediment) transport submodel.

Because the movements and adsorption capacities of sediment vary significantly with size or type, the sediment transport submodel simulates transport, deposition, and resuspension of three size fractions of cohesive and noncohesive sediments. The dissolved-contaminant transport submodel includes mechanisms of adsorption/desorption, as well as decay and degradation resulting from hydrolysis, oxidation, photolysis, volatilization, and biological activity, where applicable. The particulate-contaminant transport submodel simulates transport, deposition, and erosion of contaminants associated with each sediment size fraction.

Adsorption/desorption mechanisms are expressed by a distribution coefficient and a transfer rate that describes how quickly dissolved-and particulate-contaminant concentrations reach their equilibrium condition. These formulations assume that adsorption/desorption mechanisms are completely reversible. However, in reality these mechanisms are not necessarily fully reversible.

SERATRA/TUDAM predicts changes of bed conditions for sediment and particulate contaminants, including a) riverbed elevation changes because of sediment deposition and scour, b) longitudinal and vertical size distributions of bed sediment, and c) longitudinal and vertical distribution of particulate contaminant in the riverbed. The model also includes the effects of armoring. Armoring occurs when larger sediment-sized particles in the bed form a protective layer over the smaller particles (Graf 1971).

Input data required by SERATRA/TODAM is fairly extensive and is determined by the modeling scenario. A typical list of input data and simulation output is as follows:

- Common data requirements for all the submodels:

- channel geometry 
- discharges of tributaries, overland runoff and other point and nonpoint sources

- longitudinal (TODAM)/vertical (SERATRA) dispersion coefficient

- Additional requirements for hydrodynamic submodel

- Manning roughness coefficients

- Initial conditions - depth and velocity distribution

- Boundary conditions - depth and/or velocity distributions at the upstream boundary

- Additional requirements for sediment transport submodel

- sediment size fraction

- sediment density and fall velocities for sand, silt, and clay

- critical shear stresses for erosion and deposition of cohesive sediment (silt and clay)

- erodibility coefficient and cohesive sediment

Initial Conditions

- sediment concentration for each sediment size fraction

- bed sediment size fraction distribution

Boundary Conditions

- sediment concentration at the upstream end of the study reach

- contributions of sedinents from overland, tributaries and other point and nonpoint sources

- Additional requirements for dissolved and particulate contaninant transport submodels

- distribution coefficients and transfer rates of contaminant with sediment in each sediment size fraction (i.e., sand, silt, and clay)

- degradation and decay rates of contaminants 
Initial Conditions

- dissolved contaminant concentration

- particulate contaminant concentration for each sediment size fraction (i.e., those attached to sand, silt and, clay, etc.)

Boundary Conditions

- dissolved and particulate contaminant concentrations for each sediment size fraction at the upstream end of the study reach

- contributions of dissolved and particulate contaminant concentrations from tributaries, overland, and other point and nonpoint sources

With the input data described above, SERATRA/TOUAM simulates the following:

1) Hydrodynamic simulation for any given time

- longitudinal distributions of depth and velocity

2) Sediment simulation for any given time

- longitudinal distributions of total sediment (sum of suspended and bed load) concentration for each sediment size fraction

- longitudinal distribution of sediment size fractions in the river bed

- change in bed elevation (elevation changes due to sediment deposition and/or scour)

3) Contaminant simulation for any given time

- longitudinal distribution of dissolved contaminant concentration

- longitudinal distribution of contaminant concentration adsorbed by sediment for each sediment size fraction

- longitudinal and vertical distributions of contaminant concentrations in the bottom sediment within the bed for each

sediment size fraction 
SERATRA was applied to a large river (the Columbia River--approximately 100-km reach) near the Hanford Site, Washington (Unishi 1977); an intermediate size river (the clinch River--approximately $37-\mathrm{km}$ reach) near Oak kidge National Laboratory, Tennessee (Unishi et al. 1979); and very small streams (Four Mile and Wolf Creeks--approximately 68-km reach) in central Iowa (Unishi and wise 1979). In these cases, SERATRA simulated migration of sediment, radionuclide and pesticide transport. TODAM has been applied to the Mortandad and South Mortandad Canyons, Los Alamos, New Mexico, (Unishi, Whelan, and Skaggs 1982) to simulate the migration and fate of sediment and radionuclides in these canyons, which experience intermittent flows. It also has been applied to the stream channels at the Environmental Protection Agency's Monticello Ecological Research Station, Monticello, Minnesota (Parkhurst, Whelan, Onishi, and 0lsen 1981). TODAM was used to simulate the migration, fate, and effects of the organophosphate pesticide diazinon in conjunction with the Chemical Migration Risk Assessment Methodology (CMRA, Onishi et al. 1979 and 01 sen and Wise 1979).

The SERATRA/TUDAM model(s) has several limitatons: a) it may require extensive input data, which may limit its applicability, b) it requires extensive computer time, and thus a long-term continuous simulation may be prohibitive, c) it treates the adsorption/desorption mechanism as completely reversible, and d) it requires hydrodynamic input from an independent source (e.g., a hydrodynamic model).

In many instances a one-dimensional model (uniform distribution in the vertical and transverse directions) is more applicable than a multi-dimensional model. TODAM is suitable to many rivers and estuaries where vertical and lateral distributions of sediments and contaminants are not a major concern. Because this is a one-dimensional model, it is more compatible with most hydrodynamic codes (which are one-dimensional) than multi-dimensional models are.

\subsubsection{Model Coupling}

To adequately simulate the migration of radionuclides through the watersediment transport pathways, the selected models had to be coupled at appropriate interfaces. Figure 4.13 presents the coupling methodology for the 


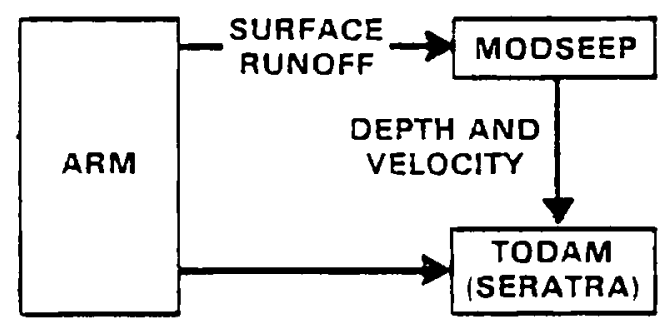

SEDIMENT LOADING

AND

RADIONUCLIDE

LOADING

FIGURE 4.13. Model Coupling and Information Transfer

models and the information transferred at each interface. ARM is the first model in the system. Meteorological information (precipitation, solar radiation, dew point temperatures, max-min temperatures, wind speed, etc.) is supplied to ARM so ARM parameters controlling evapotranspiration, interception, snowmelt, and soil erosion (as it is affected by forest density) can be estimated. ARM generates information which represents boundary conditions for the models MODSEEP and TODAM. ARM provides MODSEEP with edge-of-stream water discharge information. This information represents the upstream boundary condition and lateral inflow to the channel. ARM provides TODAM with edge-ofstream sediment and radionuclide (where appropriate) loadings. The upstream boundary conditions are expressed as concentrations, while the lateral inflow information is expressed as a flux. The second model in the system, MUDSEEP, performs the hydrodynamic simulation in the channel and provides the in-stream flow discharge, cross-sectional area, flow depth, shear stress, net inflow, water temperature, and wetted perimeter for use by TODAM. TODAM, the third model in the system, simulates the in-strearn migration and fate of sediments and radionuclides. For various modeling scenarios, certain precipitationproduced channel flood events may not be significantly large to encompass all active and inactive radionuclide storage areas. Most flood events, though, having return periods significantly larger than the $38 \mathrm{yr}$ of record of contamination in the Los Alamos area (contamination started in 1943) will partially or totally encompass inactive radionuclide storage areas. In order 
to insure that areas of highest contamination are included in any modeling scenario, this contamination is included in the channel where the majority of the flood event occurs. This is necessary because no contaminant transport model simulates the interrelationships between partially inundated storage areas, bank areas, and the main channel area for the migration and fate of contaminants and various sediment types. TODAM is one of the most sophisticated contaminant transport codes and so far only includes algorithms considering vertical variations in bed contamination. Large flood events, though, will inundate all contaminated areas and these areas will represent the flow of the channel.

Einploying the scenario mentioned above will not reduce the possibility for movement of radionuclides downstream; on the contrary, it will enhance it. The contaminants will be concentrated in the area of the channel where the flow velocity is highest, enhancing the chances for entrainment of contaminated sediment. ARM, therefore, will not be used to simulate the migration and fate of radionuclides overland. ARM will be used, though, to simulate the movement of water and sediment overland. TODAM will be the model simulating the primary migration of radionuclides downstream.

\subsubsection{Precipitation and Flood Event Scenarios}

For approximately 30 years, radionuclide effluent has been discharged into A-P and UP-LA Canyons. Over this time, radionuclides (mainly ${ }^{239} \mathrm{Pu}$ ) have adsorbed to sediment, and the banks and bed of the canyons have been contaminated at various depths with various activity levels. As mentioned earlier, Figures 4.11 and 4.12 and Tables 4.7 through 4.11 present levels and locations of the radioactive contamination. Under certain conditions (i.e., extreme flood events), the contaminated sediment may be resuspended and transported downstream toward the Rio Grande. The objective herein is to investigate the conditions under which a significant amount of radionuclides will be resuspended and transported downstream. It should be noted that as the size of the storm increases, the amount of contaminant (sediment and radionuclides) transported downstream increases; this does not necessarily mean that the contaminant concentrations will increase as well. In fact, the contaminant concentrations may even decrease. 


\section{Precipitation Scenario}

Very little precipitation data exists for the Los Alamos area. No correlations exist between the spatial and temporal distributions of precipitation, flood events, and the LoS Alamos site. The representative storms of the Los Alamos region are not uniformly distributed, spatially or temporally, but are highly localized with variable durations. The return period for a precipitation event is a function of the depth of rainfall and the duration of the event. Correlating recurrence intervals between precipitation and flood events becomes very difficult. This is especially true if the spatial distribution of the rainfall event is localized to one portion of the catchment.

Within the context of this modeling scenario, description of the flood event becomes very important, since all of the contamination is in the area of the channels. The flood event, though, is a function of the precipitation event and the overland and in-stream hydrodynamic modeling. The overland modeling depends upon the distribution of the precipitation with the rainfall intensity appearing to be the critical precipitation parameter. Because of this, several precipitation events representing different return periods could produce flood events of the same recurrence interval.

Because of the lack of relevant watershed information on the distribution of the precipitation events, it is assumed that the rainfall is uniformly distributed in space over the catchment. (a) Technically, this assumption is incorrect, but not necessarily erroneous since the flood event dictates the instream migration of contaminants and sediments. Several precipitation events with varying durations, intensities, and spatial distributions can produce runoff events with the same return period on the same catchment. It is difficult to decide based on the information available which precipitation event is more representative of the flood event of a given recurrence interval, since only the peak discharges are known. The major difference between the precipitation-produced flood events is accounted for in the temporal distribution of the rising and falling limbs of the resulting flood hydrographs.

(a) Acid-Pueblo and BP-Los Alamos Canyons represent different watersheds. 
Since the major sediment-producing portion of the flood hydrographs is in the area of the peak discharge, the differences in the temporal distribution of the rising and falling limbs of the various flood hydrographs may be insignificant.

\section{Precipitation Frequency}

Based on the isopluvials in the National weather Service (NWS) NUAA (National Oceanic and Atmospheric Administration) Atlas-2 for 6-hr and 24-hr precipitation depths, Los Alamos researchers computed rainfall frequency estimates for the Los Alamos, New Mexico area. Table 4.13 and Figure 4.14 present estimated rainfall depths for given durations and given return periods. Maximum 24-hr precipitation depths for Los Alamos are presented in

TABLE 4.13. Precipitation Frequency Estimates for Los Alamos, NNM $\left[\left(106^{\circ} 19^{\prime} \mathrm{W}, 35^{\circ} 52^{\prime} \mathrm{N}\right.\right.$, Elev. $=2258.6 \mathrm{~m}$
tion Frequency Atlas, "NOAA At las $\left.-2^{\prime \prime}\right]$

\begin{tabular}{|c|c|c|c|c|c|c|c|c|}
\hline \multirow{3}{*}{$\begin{array}{l}\text { Return } \\
\text { Period } \\
\text { Tr }\end{array}$} & \multicolumn{8}{|c|}{ Estimated Rainfall Depths in Inches for the } \\
\hline & 15-min & 30-min & $60-\mathrm{min}$ & $2-h r$ & $3-h r$ & $6-h r$ & $24-h r$ & $\overline{\text { Annua T }}(a)$ \\
\hline & $P_{15}$ & $P_{30}$ & $P_{60}$ & $P_{2}$ & $P_{3}$ & $P_{6}$ & $P_{24}$ & $P_{A}$ \\
\hline 2 & 0.56 & 0.77 & 0.98 & 1.11 & 1.20 & 1.36 & 1.76 & 17.99 \\
\hline 5 & 0.72 & 1.00 & 1.26 & 1.42 & 1.53 & 1.74 & 2.32 & 24.06 \\
\hline 10 & 0.82 & 1.13 & 1.43 & 1.62 & 1.75 & 2.00 & 2.67 & 25.79 \\
\hline 25 & 0.95 & 1.31 & 1.66 & 1.89 & 2.04 & 2.32 & 3.14 & $27.9(c)$ \\
\hline 50 & 1.07 & 1.49 & 1.88 & 2.13 & 2.30 & 2.61 & 3.57 & $29.0(c)$ \\
\hline 100 & 1.19 & 1.64 & 2.08 & 2.36 & 2.55 & 2.90 & 4.00 & 30.24 \\
\hline
\end{tabular}

(a) Source: Miller, J. F., R. H. Frederick, and R. J. Tracey. 1973. NOAA Atlas-2, "Precipitation-Frequency Atlas of the Western United States, Volume IV-New Mexico," U.S. Uept. of Commerce, NOAA, National weather Service, Silver Spring, MU. (b) Source: Abeele, W. V., M. L. Wheeler, and B. W. Burton. 1981. "Geohydrology of Bandelier Tuff", Los Alamos National Laboratory Report, Manuscript in Press.

(c) Interpolated values. 


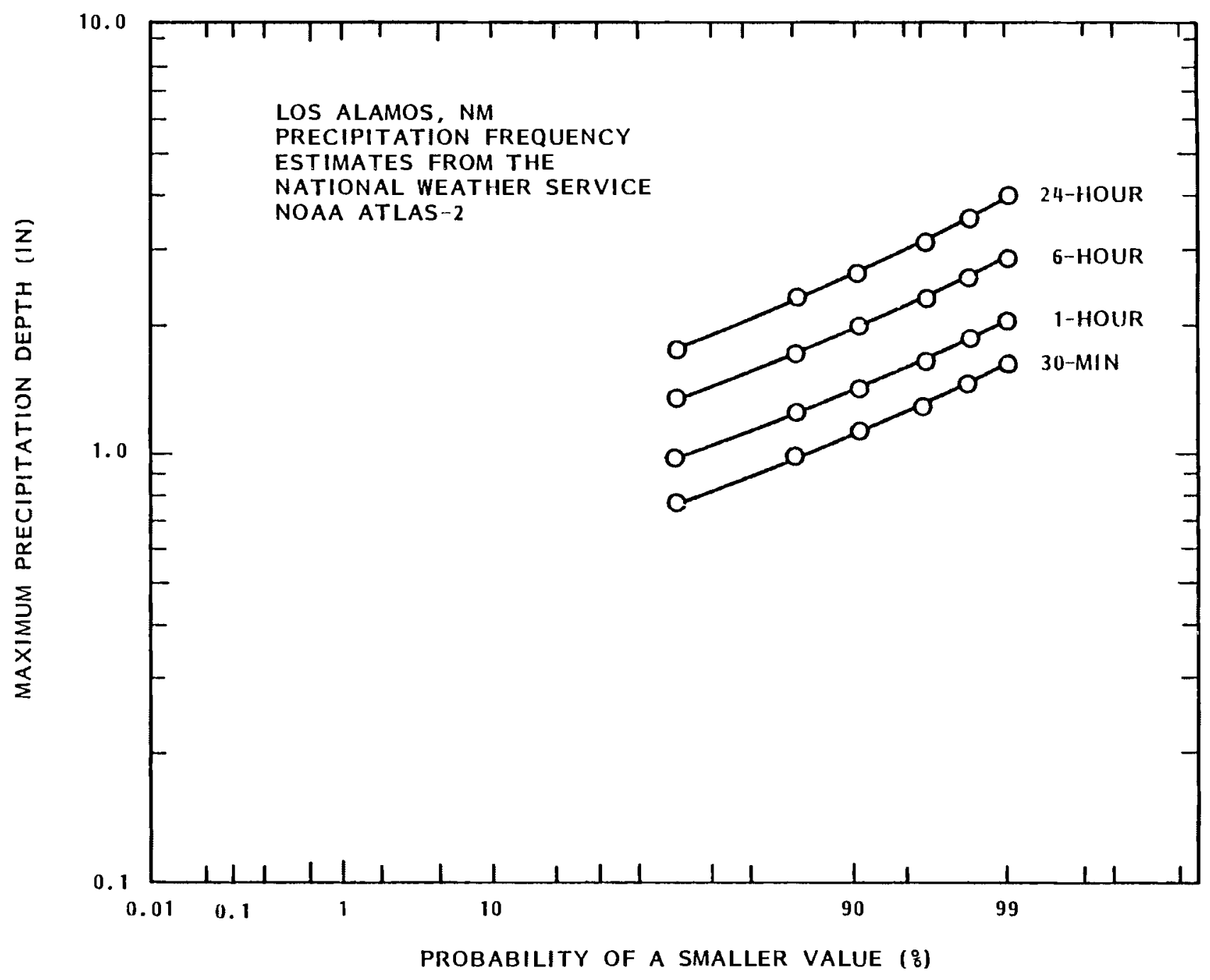

FIGURE 4.14. Los Alamos Precipitation Frequency Estimates from the National Weather Service NOAA Atlas-2

Figure 4.15. Also presented in Figure 4.15 are the corresponding estimates from the NWS NOAA Atlas-2. Both curves appear linear in Figure 4.15 with the NOAA Atlas-2 estimates consistently 20 higher than tnose suggested by Los Alamos observations. The differences are clearly illustrated in Figure 4.16. With these relationships, the values for the rainfall depths as provided for in Table 4.13 were adjusted for the Los Alamos area. For the modeling exercise, the estimated rainfall depths with various durations were adjusted based on the 


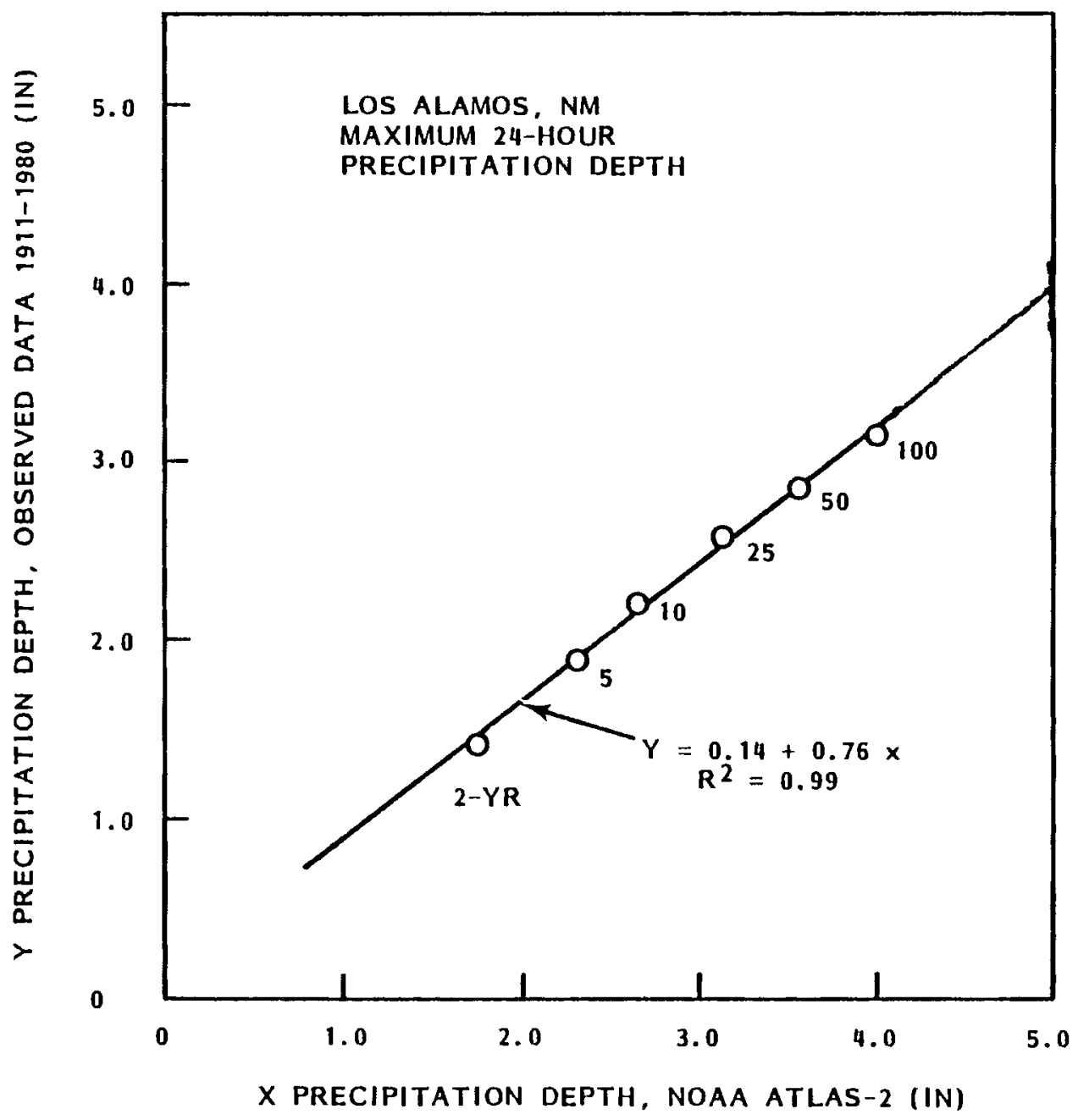

FIGURE 4.15. Los Alamos Maximum 24-Hour Precipitation Frequency

ratio of the maximum 24-hr precipitation depths from the NOAA Atlas-2 and observed Los Alamos data (see Figure 4.15). Very little precipitation data existed for the Los Alamos area. No correlation between the spatial and temporal distributions of precipitation, flood frequency events, and the Los Alamos site exists. Because of this, accurate correlation of return periods for precipitation and flood events on the watershed is difficult.

\section{Flood Frequency}

Because the size of the flood event determines the amount of contaminants transported downstream, return periods for A-P and DP-LA Canyons have been 


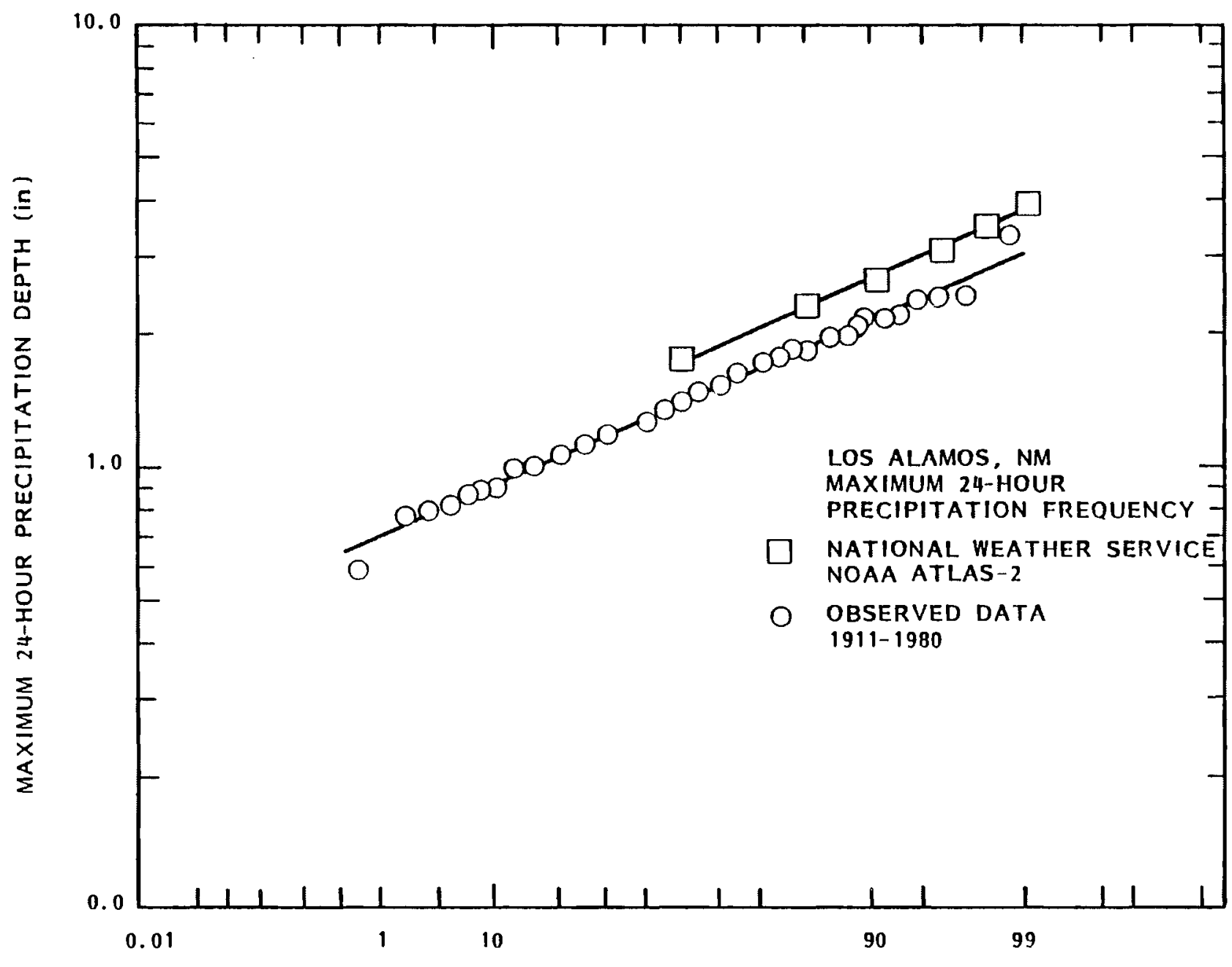

PROBABILITY OF A SMALLER VALUE (

FIGURE 4.16. Relation Between Ubserved and Estimated Maximum 24-Hour Precipitation Amounts at Los Alamos for Return Periods of 2 to 100 Years

estimated. In addition, these estimates could be used to correlate the recurrence intervals of precipitation events and corresponding return periods of simulated flood events. It should be noted, though, that the return periods for precipitation and corresponding flood events do not have to be the same. The corresponding flood event is a function of the areal distribution, duration, intensity, etc., of the precipitation event and watershed characteristics at thetime of occurrence of the event. LANL (1981) presents various return periods (i.e., 2-yr, 5-yr, 10-yr, 25-yr, and 50-yr) for A-P and DP-LA Canyons. These are presented in Table 4.14. 
TABLE 4.14. Flood Frequency and Maximum Discharge for Acid-Pueblo and DP-Los Alamos Canyons (LANL 1981)

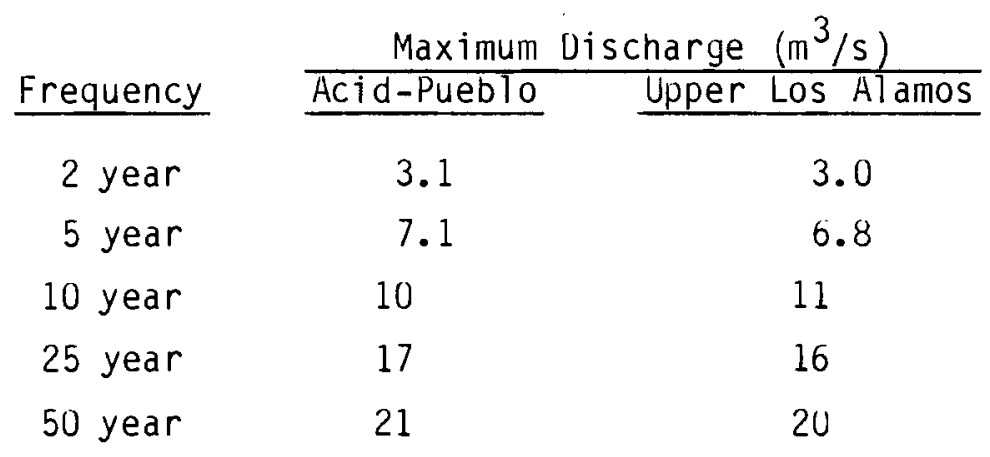

These return periods were based on research by Scott (1971).(a) Scott presented data on flood characteristics for 163 sites where flood records had been obtained for eight or more years, and on the maximum known floods at 439 sites. All of these sites were contained within the state borders of New Mexico. These analyses consisted of defining the relationships between the flood data and the physical and climatic characteristics at the gaged sites. An estimate of the natural-peak flow could then be obtained for any desired site by using this relationship and the basin characteristics at the desired site.

The magnitude and frequency of the floods were defined regionally for streams in New Mexico. Multiple regression techniques were employed for relating the selected physical and climatic basin characteristics (i.e., area, overland slope, temperature, mean basin altitude, etc.) to flood peaks having recurrence intervals of $2,5,10,25$, and 50 years. The recurrence intervals were determined using the Log Pearson Type III methodology. None of the gages recording stream flow were associated with the Los Alamos area. The information provided by Scott (1971), though, was used to develop recurrence interval curves for the Los Alamos area. Information pertaining to three nearby watersheds, with drainage areas similar in size (considering the data presented by Scott 1971) to that of the UP-LA and A-P basins along with the information

(a) Scott (1974) and Scott and Kunkler (1976) present further information pertaining to floods from small drainage areas in New Mexico. 
provided by Table 4.14 were employed in developing Log Pearson Type III recurrence interval curves for A-P and DP-upper Los Alamos catchments. Peak discharge versus recurrence interval for five catchments (DP-upper Los Alamos and A-P watersheds represent two of the five) are presented in Figure 4.17 . Supporting information pertaining to these curves are presented in Table 4.15. Several items should be noted pertaining to Figure 4.17 and Table 4.15:

1) Recurrence intervals greater than 50 years were computed for Watersheds 82920, 83025, and 83219 based on Scott's (1971) LogPearson Type III analysis for recurrence intervals less than 50 years.

2) The results presented in Table 4.15 were based on a multiple regression analysis for the entire state of New Mexico and may be inaccurate for the Los Alamos Area.

3) The peak discharge-recurrence interval curves for the UP-upper Los Alamos and A-P basins were developed by fitting Log-Pearson Type III curves to the information presented in Table 4.15. The shape of these curves was based on the shapes of the curves for watersheds 82920,83025 , and 83219.

Relating Precipitation and Flood Events

Precipitation and flood events were related through a trial and error simulation procedure on Acid-Pueblo Canyon. Various precipitation events with different rainfall intensities (uniformly distributed spatially) were simulated on Acid-Pueblo Canyon. ARM used these precipitation events as boundary conditions to produce edge-of-stream runoff. MODSEEP used ARM's edge-of-stream information as boundary conditions and routed the various flood waves through the canyon. Based on this trial and error procedure between various precipitation and flood events, a maximum rainfall intensity of $0.66 \mathrm{~cm} / \mathrm{hr}$ and a peak runoff discharge at the mouth of A-P Canyon of $22.97 \mathrm{~m}^{3} / \mathrm{s}$ produced a $50-y r$ flood event for A-P Canyon based on the information supplied by Figure 4.17 and Table 4.15 . 


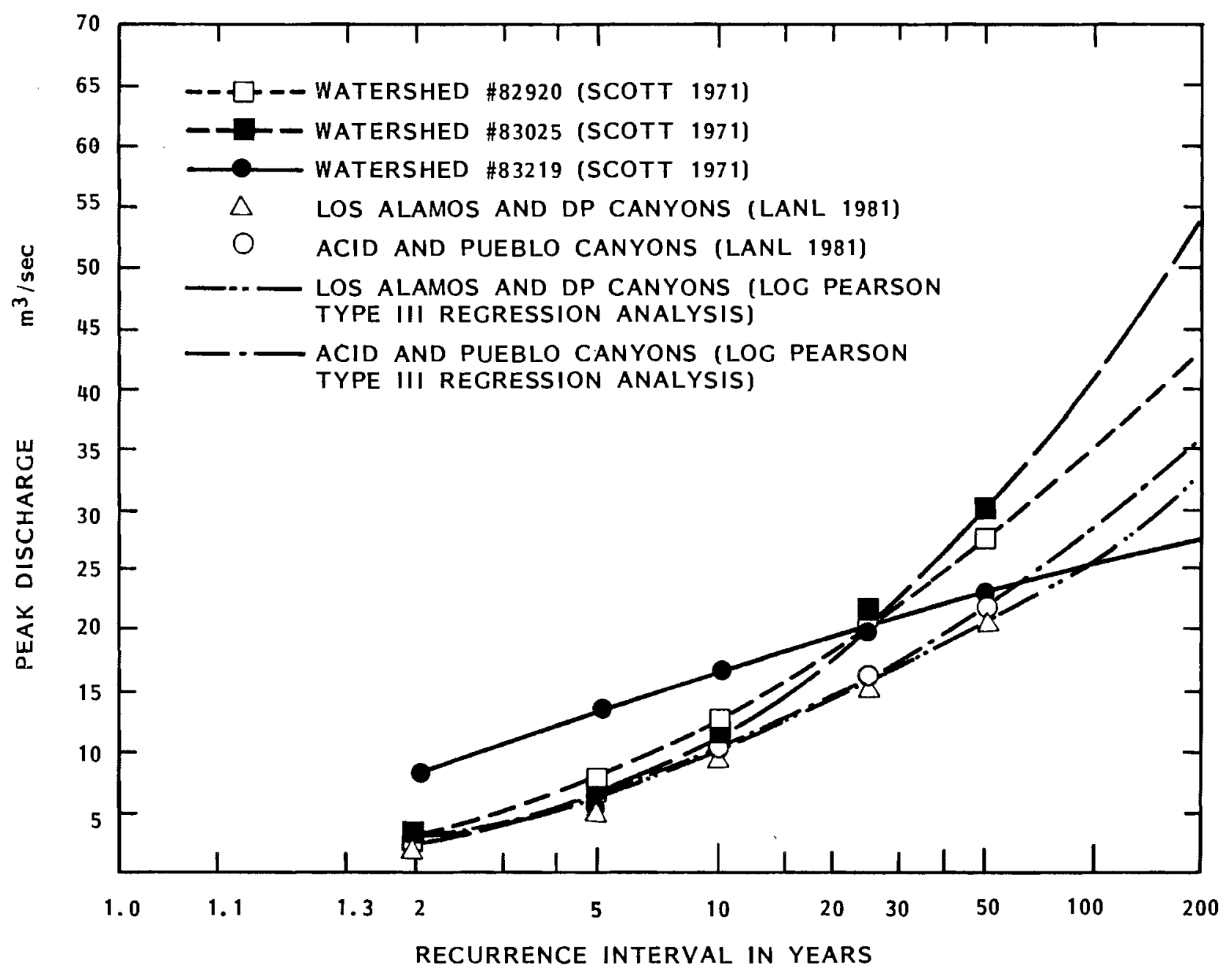

FIGURE 4.17. Peak Discharge Versus Recurrence Intervals for Five Catchments in and Around the Los Alamos Area

TABLE 4.15. Supplementary Information Related to the Curves in Figure 4.17

\begin{tabular}{|c|c|c|c|c|}
\hline Watershed & $\begin{array}{c}\text { Years of } \\
\text { Record }\end{array}$ & $\begin{array}{l}\text { Drainage } \\
\text { Area }\left(\mathrm{km}^{2}\right)\end{array}$ & $\begin{array}{c}\text { Skew } \\
\text { Coefficient } \\
\end{array}$ & $\begin{array}{l}\text { Standard } \\
\text { Deviation }\end{array}$ \\
\hline $82920(a)$ & $23(a)$ & $89.4(a)$ & $-0.260(b)$ & 0.4998 (b) \\
\hline $83025(a)$ & $32^{(a)}$ & $30.3^{(a)}$ & $0.142^{(b)}$ & $0.5852^{(b)}$ \\
\hline $83219^{(a)}$ & $12^{(a)}$ & $69.4^{(a)}$ & $0.650^{(b)}$ & $0.4136^{(b)}$ \\
\hline DP-Upper Los Alamos & -- & 27.5 & $-0.100^{(c)}$ & $0.4279(c)$ \\
\hline Acid-Pueblo & -- & 22.3 & $-0.100^{(c)}$ & $0.4350(c)$ \\
\hline
\end{tabular}

(a) Scott 1971.

(b) Computed using Log-Pearson Type II I methodology.

(c) Estimated using Log-Pearson Type III methodology. 


\subsection{OVERLAND SEDIMENT-CONTAMINANT TRANSPORT MODELING}

\subsubsection{Int roduction}

The overland flow and sediment transport for this study were simulated by ARIM, a lumped-parameter model which simulates hydrologic processes and contaminant migration in a watershed. A description of ARM appears in Section 4.1.3. The section presented below describes the numerical modeling representation of the study region; the calibration of the model witnin the limits of the available precipitation, streamflow, and sediment data; and the application of the model to Acid and Pueblo Canyons. The results of the ARM simulation provide the requisite upstream and lateral inflow boundary conditions for MODSEEP, the in-stream hydrodynamic model. The results also provide the upstream and edge-of-stream sediment concentrations and fluxes for TUDAM, which simulates the migration and fate of in-stream sediments and radionuclides.

\subsubsection{Numerical Modeling Representation}

As stated in Section 4.1.3, ARM does not include the effects of channel processes on runoff and sediment transport and is thus applicable to watersheds that are small enough that channel processes can be assumed negligible. For large watersheds, it is therefore necessary to subdivide the catchment into smaller subcatchments. The size limitation will vary from region to region due to climatic and topographic characteristics. However, it is recommended that the upper limit on the size be about 2 to $5 \mathrm{~km}^{2}$ (1 to $2 \mathrm{mi}^{2}$ ) (Donigian and Davis 1978).

Figure 4.18 shows the numerical modeling representation of the study area. Table 4.16 presents the characteristics of the individual areas. This information is required as input to ARM and was determined by inspection of topographic maps and available literature. Note that LA-1 is larger than the recommended size to be used for the application of ARM. It was decided that this drainage area should be included as one, since a run-of-the-river dam is controlling its flow and very little information is available regarding this area or the dam. Characteristics presented in Table 4.16 include the watershed 


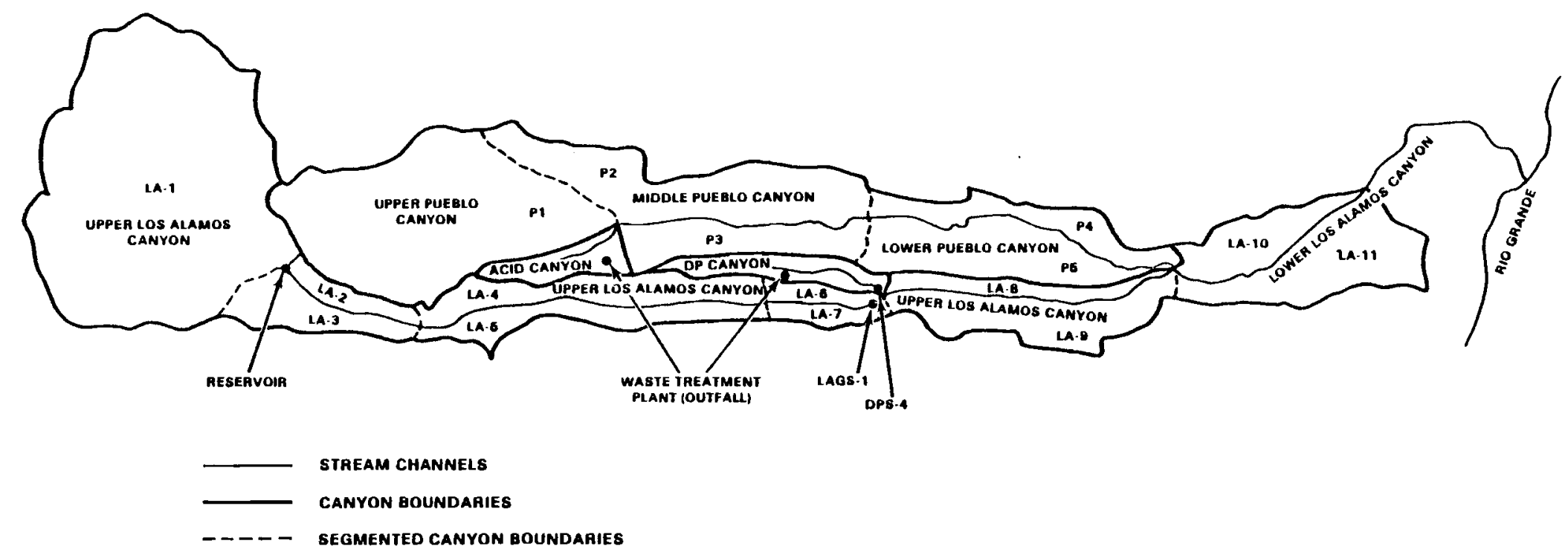

FIGURE 4.18. Subdivision of the Study Area for Application of ARM 
TABLE 4.16. Watershed Characteristics Required for Application of ARM

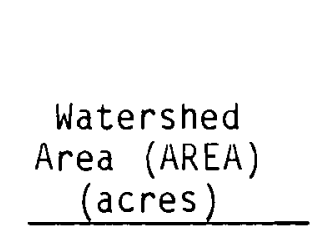

Overland

Flow

Length Overland

(L) Gradient

$(\mathrm{ft})$

(SS)

Upper Los Alamos Canyon

LA-1

$L A-2$

3724

182

LA-3

LA-4

LA-5

316

581

414

LA-6

119

LA-7

140

DP Canyon

DP

396

Upper Los Alamos Canyon

$\begin{array}{ll}\text { LA-8 } & 260 \\ \text { LA-9 } & 681\end{array}$

Acid Canyon

A1

13

A2

254

Upper Pueblo Canyon

P1

2324

Middle Pueblo Canyon

P2

P3

1147

531

Lower Pueblo Canyon

P4

464

792

0.05

0.0

0.01

0.10

0.14

6600

0.00

0.20

0.11

0.15

7841

P5

Lower Los Alamos Canyon

$\begin{array}{ll}\text { LA-10 } & 424 \\ \text { LA-11 } & 810\end{array}$

1108

0.106

0.081

$\begin{array}{ll}3173 & 0.066 \\ 1612 & 0.053\end{array}$

0.19

1912

0.29

0.01

0.05

0.05

6582

0.00

0.05

0.05

7159

7077

1566

0.095

0.03

0.05

6145

2459

0.00

0.05

6173 
area (AREA), the overland flow length ( $L$ ), the average overland gradient (SS), the fraction of the area that is impervious (A), the fraction of the watershed with complete forest cover (F), and the mean elevation of the watershed (MELEV). In estimating a value for SS, the large elevation gradients in the canyon cliffs were not considered. Instead, it was assumed that any flow and sediment which reached the top edge of the cliff cascaded to the bottom of the cliff to enter the stream. Table 4.16 indicates that Acid Canyon was subdivided into two areas. The smaller area (Al) was used in defining the upstream flow and sediment boundary conditions.

\subsubsection{Model Calibration and Results}

Introduction

Hydrologic calibration requires the availability of known meteorological data for a selected time period and associated runoff data recorded during the same period on the drainage area receiving the precipitation. The runoff volumes and individual storm hydrographs simulated by ARM, using the meteorological data as input, are compared with the recorded runoff data. Calibration parameters are adjusted until there is reasonable agreement between simulated and recorded runoff.

Precipitation and runoff data were very limited for the study region. An in-depth calibration of ARM to the study region was therefore precluded. However, a calibration based on individual storm hydrographs had been performed in an earlier PNL study (Onishi, Whelan, and Skaggs 1982) for near-by Mortandad Canyon (see Figure 4.1). It was expected that the Mortandad Canyon calibration values would be used in the present study because of the data limitations for the present study region, the proximity of Mortandad Canyon to the present study region, and the similarity of the watershed characteristics of the two regions.

Since limited runoff information was available for four storms in DP Canyon, ARM was applied to DP Canyon to evaluate the reasonableness of the simulated hydrographs using the Mortandad Canyon calibration values. The value assumed for the fraction of impervious area (A) was found to significantly affect peak flow values. It should be noted that a significant reduction in 
the estimated $A$ value was required in the earlier Mortandad Canyon calibration (Onishi, Whelan, and Skaggs 1982). In the Mortandad Canyon calibration, ARM was found to be quite sensitive to the value chosen for the parameter "A", the fraction of the watershed that is impervious. The impervious area in the catchment was estimated to be approximately 10\%. However, in the calibration this value had to be reduced to approximately $1 \%$. This sensitivity is likely the result of the assumption within ARM that all impervious areas are located adjacent to the stream channel; this assumption does not apply to the catchment modeled in the Mortandad study or to the subcatchments of the present study area. The sensitivity to A was also observed in the DP calibration. The reduction, albeit smaller, was also required in the DP Canyon application. This topic for DP Canyon is discussed under the section entitled "DP Canyon Calibration."

The ARM precipitation input data set constructed for the Mortandad Canyon study was used for DP Canyon because the three recording rainfall gages on which the data set is based are the only ones in the vicinity of the project study area. However, precipitation in the Los Alamos region is characterized by significant spatial variation in rainfall. Isohyetal estimates provided some information regarding total precipitation depths in UP Canyon as compared with Mortandad Canyon. These estimates were considered in evaluating the simulated hydrographs for DP Canyon. The lack of information regarding precipitation distributions specific to DP Canyon and the limitations of the measured runoff data did not justify making changes in calibration parameters for the DP Canyon application.

Suspended sediment concentrations measured during three different storms at DPS-4 (see Figures 4.2 and 4.5) were available. These provided a basis for sediment calibration parameter adjustment and for evaluation of suspended sediment concentrations predicted by ARM for DP Canyon.

Simulations were also run for upper Los Alamos Canyon. The overland flow was input to MODSEEP in order to simulate the one storm in the meteorological input data set for which corresponding runoff information was available (at 
LAGS-1). The size of this area and lack of precipitation distribution information specific to the area precluded the use of this information for adjustment of calibration parameters.

This section discusses the standard calibration procedure of ARM and presents the data available for calibration of ARM to the study area. Results of the application of ARM to Mortandad Canyon, UP Canyon, and Acid and Pueblo Canyons are also discussed.

\section{Standard Calibration Procedure}

Hydrologic calibration involves comparison of simulated and recorded runoff volumes and individual storm hydrographs for a calibration period of 1 to 3 years. The volume comparison are made on a storm, daily, monthly, or yearly basis. The selection will depend on the watershed area, the length of the available calibration period, and the available data (Donigian and Davis 1978). Data required for simulation of hydrologic processes within the watershed include precipitation and potential evapotranspiration; for snowmelt computations, max-min air temperature, wind movement, solar radiation, and dewpoint temperature are required. Since the ARM model is a continuous simulation model, the period of record needed for each data series corresponds to the length of time for which the calibration simulation is performed.

Comparisons between simulated and observed storm hydrographs are generally made for storm events occurring in the second year of simulation, by which time the effect of assumed initial conditions should be negligible. Calibration is performed by adjusting certain input parameters until there is reasonable agreement between observed and simulated hydrographs.

Hydrologic calibration must preceed sediment calibration which, in turn, preceeds contaminant calibration. This is necessary because runoff is the transport mechanism for sediment, and both runoff (and vertical moisture movement) and sediment are the transport mechanisms for contaminants. In this study only hydrologic and sediment simulations were required of the overland flow model; the radionuclide simulation was handled by the in-stream contaminant model, TODAM, since it was assumed that significant radionuclide concentrations existed only in the streambed (see Section 4.1.2). The most important hydrologic and sediment calibration parameters are described below. 
Four important hydrologic parameters are LZSN, INFIL, INTER, and NN. LZSN, the nominal, lower-zone, soil-moisture storage parameter, is related to the annual cycle of rainfall and evapotranspiration. INFIL is an index to the mean infiltration rate on the watershed and is generally related to soil permeability. Values for INFIL nave been estimated using the Soil Conservation Service's hydrologic soil groups (Donigian and Davis 1978). INTER affects the interflow component of runoff and is used to adjust runoff timing. NN is tine roughness coefficient for overland flow.

The two main sediment calibration parameters are KSER and KRER. KSER is the coefficient in the sediment washoff equation. It combines the effects of slope, overland flow length, sediment particle size, and surface roughness on sediment transport capacity of overland flow. KRER is the coefficient of the soil splash equation and is related to the erodibility or detachability of the specific soil type and land surface conditions.

Data which were available for calibration of these parameters are presented in the following sections.

Available Precipitation Data

ARM assumes areal uniformity in the precipitation data input for the watershed being modeled. A 15-min interval was selected for simulation calculations. (a) Thus, precipitation must be input for each 15-min interval of a given day in which there is some recorded precipitation.

Most of the rain gages in the vicinity of the study area recorded daily precipitation depths only. The temporal distribution of rainfall which occurred in a given storm event was recorded at three gages. Daily total precipitation volumes were available for storms which occurred in July and August 1976 ( 13 days) and in May through August 1977 (12 days). For the 1976 storms, the daily total volumes at the various stations were used to estimate isohyetal contours.

In an earlier modeling study of Mortandad Canyon, which is near the present study area (see figure 4.1), the data from the recording gages and

(a) Intervals allowed by ARM include 1-hr, 15-min, and 5-min. 
isohyetal estimates were used to construct a precipitation input data set covering the period from June 1, 1975 to May 31, 1977 (Onishi, Whelan, and Skaggs 1982). Other meteorological data required by ARM in order to simulate hydrological processes during this period were obtained from the stations listed in Table 4.17. In the Mortandad Canyon calibration, the first 12 months of the calibration time period were used to stabilize the simulated water balance and dampen the effect of assumed initial antecedant moisture conditions. The next two months - July and August 1976 - were used for model calibration. During this two-month period, six major storm runoff events and several smaller events were measured at two streanflow gages within Mortandad Canyon. No sediment discharge or radionuclide data were available at either station for this period. The daily totals measured at the various gages for a given storm indicate significant variability in the spatial distribution of

\section{TABLE 4.17. Sources of Meteorological Input Data} (Onishi, Whelan, and Skaggs 1982)

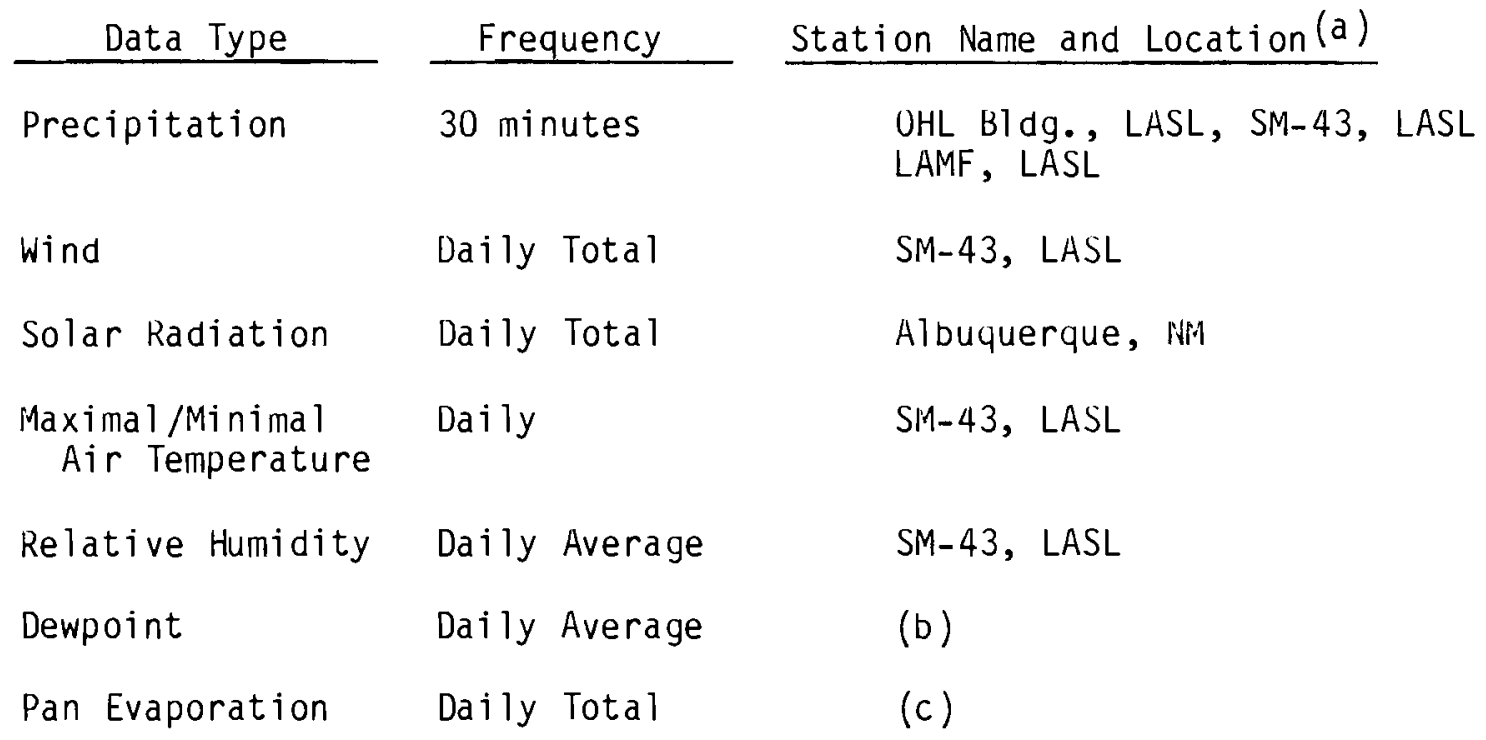

(a) LASL refers to the Los Alamos National Laboratory, formally called the Los Alamos Scientific Laboratory.

(b) Calculated from air temperature and relative humidity.

(c) Calculated from wind, solar radiation, air temperature, and dewpoint. 
precipitation over the study area. This fact and the assumption of areal uniformity of precipitation input in ARM are important limitations to the calibration of ARM to the study area.

Available Flood Flow Uata

Storm runoff information for the study area is very limited. It consists of storm runoff data (peak discharge and volume only) measured at two gages: DPS-4 in UP Canyon and LAGS-1 in LoS Alamos (LA) Canyon. The locations of these gayes are shown in Figure 4.18. As previously stated, a precipitation input data set was set up during the Mortandad study for the period between June 1, 1975 and May 31, 1977. For the second half of this period (June 1, 1976 - May 31, 1977) there were 12 storm runoff events recorded at DPS-4 and four storm events recorded at LAGS-1, as shown in Table 4.18. Of these, only four storm runoff events measured at UPS-4 had corresponding entries for that day in the precipitation input data set. These occurred on July 14, 1976; July 16, 1976; August 1, 1976; and August 11, 1976. For LAGS-1 in LA Canyon, only one recorded storm runoff event had a corresponding entry for that day in the precipitation input data set. This provides further evidence of the areal variability of precipitation in the study region. The isohyetal diagrams provided by LANL provided some information regarding the relationship between the precipitation data set and the precipitation falling in DP Canyon that same day. The isohyetal contours provide information on differences in total volume only, however; temporal distribution differences cannot be determined with the available data. For the four storms mentioned above, limited information on temporal distribution differences can be obtained by comparing the hyetographs for the three recording rain gages and total daily volume figures as presented by Onishi, Whelan, and Skaggs (1982) and LANL. The isohyetal diagrams provide little information for LA Canyon above LAGS-1 because no precipitation gages exist in the immediate vicinity of $L A-1$, which would have a significant contribution to storm runoff in the upper-most portion of LA Canyon because of its size.

The limitations in the data available for calibration precluded an in-depth calibration of ARM specifically to the study area. However, calibration of the model to Mortandad Canyon (see Unishi, Whelan, and Skaggs 1982) 
TABLE 4.18. Flow Data Measured at Gages DPS-4 and LAGS-1 During the Period of June 1, 1976 to May 31, 1977

\begin{tabular}{|c|c|c|c|}
\hline Date & $\begin{array}{c}\text { Duration } \\
(\mathrm{hr}) \\
\end{array}$ & $\begin{array}{l}\text { Peak Discharge } \\
\text { (cfs) } \\
\end{array}$ & $\begin{array}{c}\text { Volume } \\
\text { (AF) }\end{array}$ \\
\hline \multicolumn{4}{|c|}{ DP Canyon at DPS -4} \\
\hline July 14, 1976 & 7 & 17.5 & 0.81 \\
\hline July 16 & 16 & 27.0 & 1.55 \\
\hline August 1 & 8 & 17.85 & 3.98 \\
\hline August $2,3,4$, & 50 & 3.0 & 1.41 \\
\hline August 11 & 4 & 13.1 & 1.31 \\
\hline August 19 & 5 & 27.0 & 2.04 \\
\hline August 27 & 2 & 4.8 & 0.39 \\
\hline August 28 & 19 & 7.0 & 1.05 \\
\hline Apri 120,1977 & 4 & 9.8 & 1.51 \\
\hline April 21, 1977 & 11 & 17.5 & 4.39 \\
\hline May 13, 1977 & 9 & 40.8 & 7.88 \\
\hline May 14, 1977 & 8 & 22.25 & 4.02 \\
\hline \multicolumn{4}{|c|}{ LA Canyon at LAGS-1 } \\
\hline July 4, 1976 & 8 & 6.0 & 0.51 \\
\hline July 7, 1976 & 14 & 10.0 & 1.13 \\
\hline August 11,1976 & 3 & 1.18 & 0.06 \\
\hline August 19, 1976 & 9 & 4.59 & 0.98 \\
\hline
\end{tabular}

calibration of the model to Mortandad Canyon (see Unishi, Whelan, and Skaggs 1982) showed reasonable agreement between observed and simulated hydrograph volumes and monthly runoff volumes. Hydrograph data and corresponding precipitation data were avaiable for that calibration; only peak discharge and volume information and precipitation data estimated from the isohyetal contours were available for this study. The proximity of Mortandad Canyon to our study area justifies the use of Mortandad-calibrated-parameters in our study of nearby canyons. A limited calibration was possible for DP Canyon based on the isohyetal contours, runoff data measured at gage UPS-1 (see figure 4.5), and sediment data measured at DPS-1. Results of the Mortandad calibration and the DP Canyon calibration are presented below. 


\section{Mortandad Canyon Calibration}

Figures 8 through 13 and Table 5 in Chapter 4 of Onishi, Whelan, and Skaggs (1982) show the results of the Mortandad Canyon calibration. Table 4.19 presents the final values of the important calibration parameters mentioned above. LZSN was reduced to increase the peak rate of runoff and runoff volume over those of the initial calibration run. INFIL was decreased to increase runoff volume. INTER was decreased in order to allow simulation of hydrographs with higher peaks and shorter durations. The INN value is recommended for the heavy turf and forest-litter conditions found in Mortandad canyon. KSER was adjusted on the basis of a limited number of observations (one storm only) at one of the stations (outside the above-mentioned calibration period, however).

TABLE 4.19. Comparison of Initial and Final Values of ARM Calibration Parameters (Onishi, Whelan, and Skaggs 1982)

\begin{tabular}{|c|c|c|}
\hline $\begin{array}{c}\text { Calibration } \\
\text { Parameter }\end{array}$ & $\begin{array}{c}\text { Initial } \\
\text { Value }\end{array}$ & $\begin{array}{l}\text { Final } \\
\text { Value }\end{array}$ \\
\hline LZSN & 5.00 & 3.00 \\
\hline INF IL & 0.05 & 0.02 \\
\hline INTER & 3.00 & 0.02 \\
\hline $\mathrm{NNV}$ & 0.35 & 0.35 \\
\hline KSER & $0.01-5.00$ & 8.00 \\
\hline
\end{tabular}

\section{DP Canyon Calibration}

Hydrologic. As already stated above, a limited calibration was possible for DP Canyon based on the estimated isohyetal contours, runoff data measured at gage DPS-1, and sediment data measured at DPS-1. The Mortandad Canyon precipitation input data set was used to simulate the period from June 1, 1975 to August 31, 1976. The isohyetal contours were considered in comparing the simulated hydrographs to the observed data, consisting only of peak flow and runoff volume. Kuns were also made in which the precipitation data for the four storms having flood flow data were adjusted according to information derived from the isohyetal contours as provided by LANL. 
The value for $A$, the fraction of the area that is impervious, was reduced by a factor of four in order to get reasonable flood peaks. Mortandad Canyoncalibrated values were used for most of the calibration parameters. Other values were tried but results were most reasonable when the Mortandad values were used.

Figures 4.19 through 4.22 present the simulated runoff hydrographs for the storms which occurred on July 14, 1976; July 16, 1976; August 1, 1976; and August 11, 1976. Table 4.20 presents the precipitation depths assumed in the input data set, the range of precipitation depths estimated for the DP Canyon area on the basis of estimated isohyetal contours, and a comparison of simulated and observed data for the peak flow and total volume of the storm hydrograph. A rigorous evaluation of the results is precluded by the lack of information regarding the temporal distribution of the precipitation occurring on DP Canyon.

The temporal distribution does have a significant effect on runoff volumes. For example, if the same depth of precipitation were to occur in a shorter amount of time, the resulting higher intensity of the storm would be expected to result in a higher hydrograph peak and a higher runoff volume. Likewise, the precipitation depth of the July 14 storm would likely result in a lower simulated peak and volume if the precipitation event were to have a longer duration than assumed in the input data set. The potential for seepage is increased by the lower flow velocities. Assumptions in the ARM formulation which must be considered in an evaluation of results include spatial uniformity of precipitation over the watershed and negligible channel effects.

A sensitivity analysis was performed to investigate the effect of varying the precipitation depth for these storms while holding the temporal distribution constant. The results are presented in Table 4.21. The percent change in the peak flow is approximately the same as the percent change in precipitation depth. A greater percent change occurs in runoff volume. This information shows that a fairly minor change in the precipitation input, in terms of temporal distribution and/or total storm depth, could yield hydrograph characteristics (peak flow and total volume) which would be in reasonable agreement with observed characteristics. The spatial variability in precipitation in 

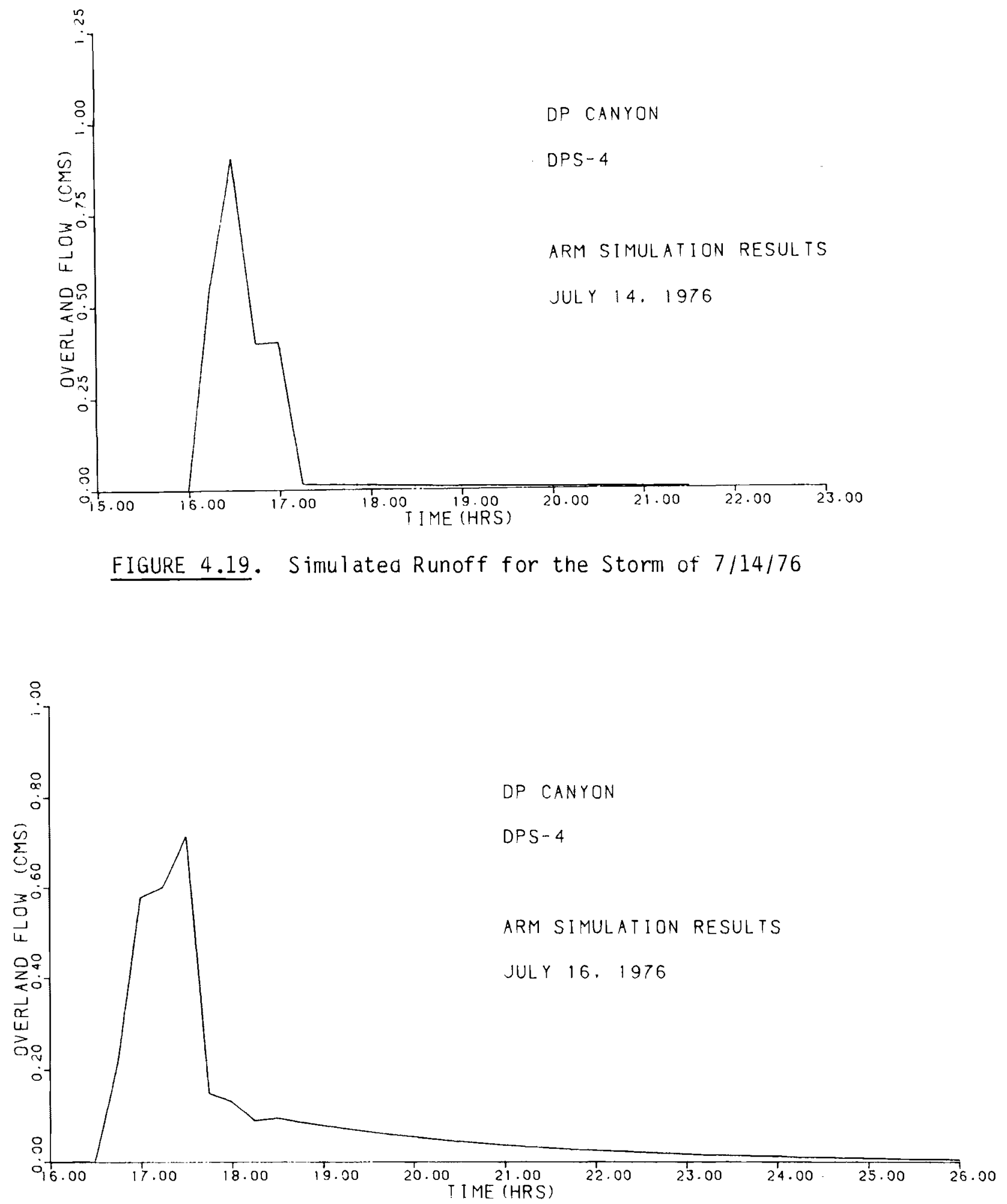

FIGURE 4.20. Simulated Runoff for the Storm of $7 / 16 / 76$ 


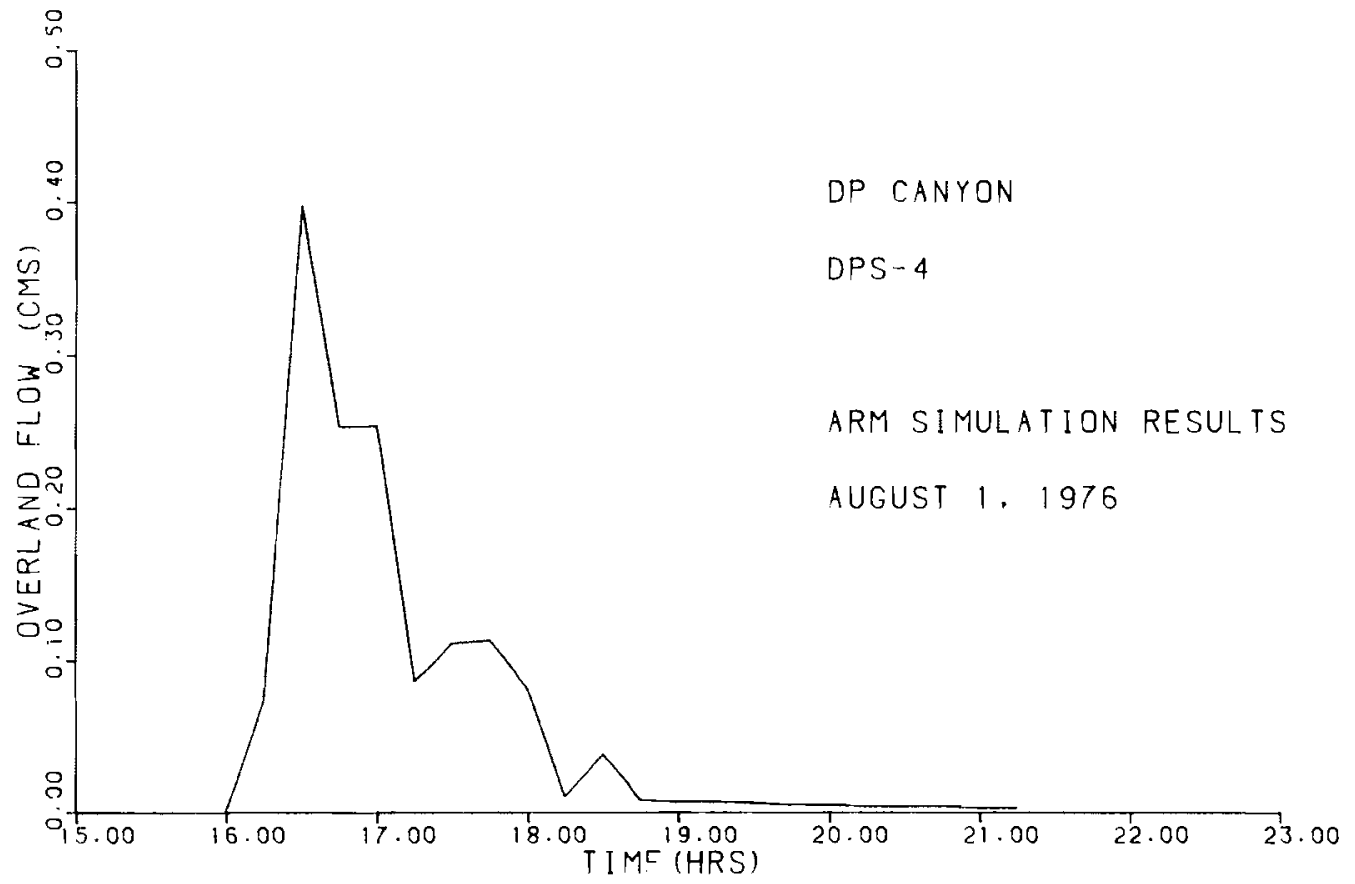

FIGURE 4.21. Simulated Runoff for the Storm of $8 / 1 / 76$

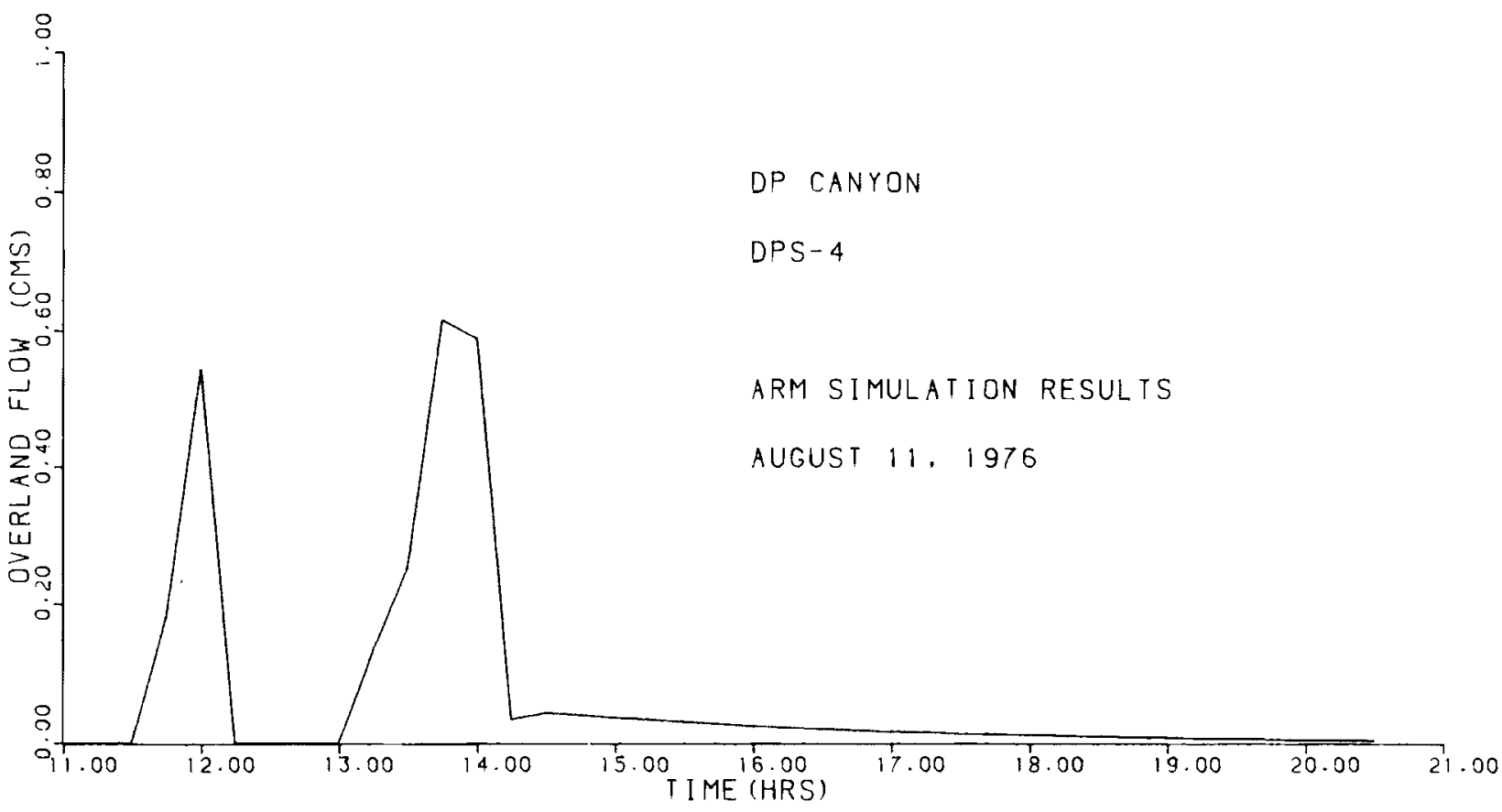

FIGURE 4.22. Simulated Runoff for the Storm of $8 / 11 / 76$ 
TABLE 4.20. Comparison of Simulated and Measured Hydrograph

Characteristics for Four Storms on DP Canyon

\begin{tabular}{|c|c|c|c|c|c|c|}
\hline \multirow{2}{*}{ Date } & \multirow[t]{2}{*}{$\begin{array}{c}\text { Input } \\
\text { Precipitation } \\
\text { (in.) }\end{array}$} & \multirow[t]{2}{*}{$\begin{array}{c}\text { Estimated } \\
\text { DP Canyon } \\
\text { Precipitation } \\
\text { (in.) } \\
\end{array}$} & \multicolumn{2}{|c|}{ Peak Flow (cfs) } & Volume & $\frac{(A F)^{(a)}}{\text { Simulated }}$ \\
\hline & & & & & & \\
\hline $7-14-76$ & 0.72 & 0.7 to 1.0 & 17.5 & 32.0 & 0.81 & 1.75 \\
\hline $7-16-76$ & 1.13 & 0.1 to 0.8 & 27.0 & 25.3 & 1.55 & 2.52 \\
\hline $8-01-76$ & 0.43 & 0.5 to 0.7 & 17.85 & 14.1 & 3.98 & $1.0 y$ \\
\hline $8-11-76$ & 0.81 & 0.4 to 0.6 & 13.1 & 22.0 & 1.31 & 2.03 \\
\hline
\end{tabular}

(a) Acre-feet.

TABLE 4.21. Changes in Peak Flow and Runoff Volumes Resulting from a Change in ARM Precipitation Input

Percent

Change in

Precipitation Percent Change Percent Change

\begin{tabular}{|c|c|c|c|}
\hline Date & Depth & in Peak Flow & in Runoff Volume \\
\hline $7-14-76$ & +18 & +16 & +43 \\
\hline $7-16-76$ & -57 & -60 & -80 \\
\hline $8-01-76$ & +40 & +35 & +103 \\
\hline $8-11-76$ & -38 & -41 & -56 \\
\hline
\end{tabular}

the Los Alamos region indicates that such differences between actual DP precipitation and the assumed input precipitation are likely to exist. Adjustment of the calibration parameters on the basis of the above information was therefore not justified.

Sediment. Figure 4.23 presents suspended sediment data measured at gage DPS-1 and simulated by ARM for two hypothetical storm events. These measured data were the basis of the calibration of the sediment parameters KSER and KRER to DP Canyon. 


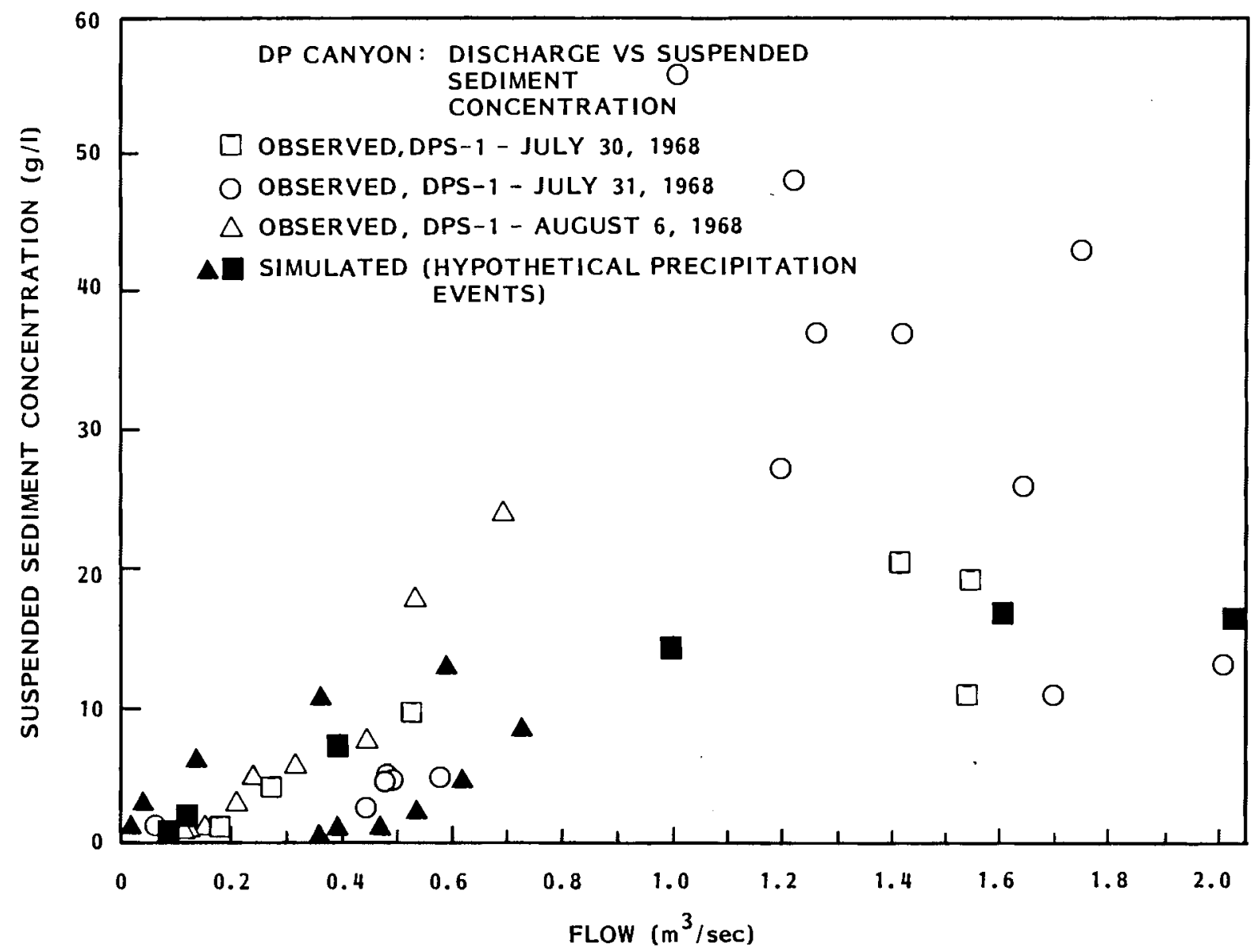

FIGURE 4.23. Comparison of Simulated and Ubserved Suspended Sediment Concentrations in DP Canyon

The sediment washoff during each simulation interval of ARM is equal to the smaller of two values: the transport capacity of overland flow or the sediment available for transport from the land surface (Donigian and Davis 1978). "Generally, washoff will be at capacity...during the beginning intervals of a significant storm event; this simulates the "first flush" effect observed in many nonpoint pollution studies. As the surface sediment storage is reduced, washoff may be limited by the sediment storage in the blocks producing the most surface runoff during the middle or latter part of storm events" (Donigian and Davis 1978).

During the calibration, the initial value of KSER was decreased in order to increase the amount of sediment washoff. The initial value of KRER was 
increased in order to increase the availability of sediment for transport (from rainfall splash). As stated in Section 4.1.3, ARM does not account for the occurrence of soil detachment and scour by the overland flow itself.

As can be seen in Figure 4.23, the simulated suspended sediment concentrations are within the range of measured data and show reasonable agreement at flow rates below approximately $0.5 \mathrm{~m}^{3} / \mathrm{s}$. [The range in simulated suspended sediment concentrations for a given flow rate, shown by the shaded triangles, results from the difference in suspended sediment concentrations between the rising and falling limbs of the hydrograph.] Hypothetical precipitation events on DP Canyon were used for the sediment calibration because the runoff volumes resulting from the storms used for the hydrologic calibration did not provide information on suspended sediment concentrations at the higher flows for which measured data were available. For high flow values, there is significant variability in the measured data and the simulated results fall within the range of the measured data, as shown in Figure 4.23.

\subsubsection{Model Application and Results}

As explained in Section 4.1.2, the modeling scenario assumes a precipitation event on Acid and Pueblo Canyons only (Areas A1, A2, P1, P2, P3, P4, and P5 on Figure 4.18). Water is routed from the head of Acid Canyon, where bed sediment radionuclide concentrations are comparatively very high, into lower Los Alamos Canyon. It is assumed that there is no runoff from upper Los Alamos and DP Canyons.

\section{$\underline{\text { Input Data }}$}

As stated in Section 4.1.5, precipitation and flood events were related through a trial and error simulation procedure on Acid-Pueblo Canyon. The desired flood event for this study was that with a return period of 50 years (see Section 4.1.2). ARM simulations for the study area were run for the period June 1, 1975 to August 15, 1976. The calibration precipitation data set resulted in simulated hydrographs with maximum return periods of only a few years. In order to simulate larger flood events, precipitation data used for July 1976 (the first month of the calibration period) was actual data recorded in July 1968, a month which included two unusually large precipitation events, 
TABLE 4.22. Precipitation Data Recorded for July 5, 1968 through August 1, 1968

\begin{tabular}{|c|c|c|c|}
\hline Day & Rainfall (in.) & Day & Rainfall (in.) \\
\hline $7-5$ & 0.1610 & $7-22$ & 0.0984 \\
\hline $7-6$ & 0.2090 & $7-23$ & 0.3898 \\
\hline $7-7$ & 0.0197 & $7-24$ & 0.1220 \\
\hline $7-9$ & 0.7520 & $7-26$ & 0.5906 \\
\hline $7-10$ & 0.2087 & $7-27$ & 0.1417 \\
\hline $7-11$ & 0.0787 & $7-29$ & 0.2280 \\
\hline $7-13$ & 0.0118 & $7-30$ & 1.0512 \\
\hline $7-15$ & 0.0197 & $7-31$ & 2.4690 \\
\hline $7-20$ & 0.0512 & & \\
\hline
\end{tabular}

events, as presented in Table 4.22. For a $24-\mathrm{hr}$ period, the rainfall depth which is estimated to occur in the study area only once every 50 years is 2.85 in. (see Section 4.1.5).

The trial and error procedure involved a determination of the temporal distribution (using 15 -min intervals) of a 2.85 inch precipitation depth within the 24-hr period of July 31, 1968 which would result in the desired magnitude flood (50-yr) being simulated by ARM and MODSEEP. Table 4.23 presents the temporal distributions which were found to give the 50-yr flood event (based on peak flow) in the study area. The observed precipitation for other days in July was assumed to have occurred uniformly over $1 \mathrm{hr}$ for amounts less than $0.5 \mathrm{in}$. and over $2 \mathrm{hr}$ for amounts greater than $0.5 \mathrm{in}$. The intensity of the precipitation event determined the magnitude of the flood peaks and the corresponding flood recurrence interval.

Table 4.16 (in Section 4.2.2) lists input data used for overland segments $A 1, A 2, P 1, P 2, P 3, P 4$, and P5. The values for $A$ were divided by four, the adjustment which was found to be most appropriate for the conditions on UP Canyon. This adjustment would be more conservative than that made in the Mortandad Canyon study since flood peaks will be higher as a result of it and more sediment will be entrained and carried by the flow. 
TABLE 4.23. Temporal Precipitation Distributions Assumed for 50-yr Flood Event

$\begin{array}{ccccc}\begin{array}{c}\text { Flood } \\ \text { Recurrence } \\ \text { Interval } \\ (\mathrm{yr})\end{array} & \frac{\begin{array}{c}\text { Rainfall } \\ (\mathrm{cm})\end{array}}{50} & \begin{array}{c}\text { Duration of } \\ \text { Precipitation } \\ (\mathrm{hr})\end{array} & \begin{array}{c}\text { Intensity } \\ (\mathrm{cm} / \mathrm{hr})\end{array} \\ & 1.63 & & 15.5 & 0.0413 \\ \text { TOTAL } & 7.61 & & 8.5 & 0.66 \\ & 7.24 & 24.0 & \end{array}$

Results

Results obtained from ARM were used in MODSEEP and TODAM for the upstream boundary condition and for lateral inflow. Table 4.24 presents the peak flows simulated by ARM for each of the segments contributing overland flow from the precipitation event. Suspended sediment concentrations were limited by sediment availability on all watersheds and were therefore similar in magnitude.

TABLE 4.24. Peak Flows Simulated by ARM for the 50-yr Flood

\begin{tabular}{|c|c|}
\hline $\begin{array}{c}\text { Watershed } \\
\text { Area } \\
\end{array}$ & $\begin{array}{c}\text { Peak Flow } \\
50 \text { Year Flood } \\
\left(\mathrm{m}^{3} / \mathrm{s}\right)\end{array}$ \\
\hline$A 1$ & 0.07 \\
\hline $\mathrm{A} 2$ & 1.4 \\
\hline P1 & 12.5 \\
\hline P2 & 6.1 \\
\hline P3 & 3.0 \\
\hline P4 & 2.5 \\
\hline P5 & 4.2 \\
\hline
\end{tabular}

The upsteam boundary conditions for flow and sediment (from Acid Canyon area $A 1)$ are included in the discussion of TODAM results, Section 4.4.2. Figures 4.31 and 4.34 of that section present the flow and sediment hydrographs from Area Al, which were used for the upstream boundary conditions for the 50-year flood event. 


\subsection{IN-STREAM HYDRUDYNAMIC MUDELING}

\subsubsection{Introduction}

The in-stream hydrodynamics for this study were simulated by HOUSEEP, a one-dimensional flood routing model designed for ephemeral streams with seepage and lateral inflow. A description of MUDSEEP appears in Section 4.1.3. MODSEEP was validated on a Mortandad Canyon reach where information from a flood wave simulation by the hydrodynamic model DKWAV (Whelan 1980) was available. Using the same input data as the UKWAV simulation, MOOSEEP computed a discharge peak at the downstream end of the study reach that closely matched the DKWAV value. This correlation was considered to be sufficient reason to apply MODSEEP in this study. After a verification phase, MOUSEEP was applied to the study reach which began at Acid Canyon, continued along Pueblo Canyon, and entered lower Los Alamos Canyon (Figure 4.24). In the Los Alamos drainage basin, streamflow is intermittent, with many of the streams becoming active only during rainfall events. The supposition of the modeling study is that isolated rainstorms of varying intensity occur in the Acid-Pueblo Canyon area. In-stream hydrodynamics are driven by rainfall runoff which enters the stream channels. In this study, ARM, an overland flow model, provides the necessary upstream and lateral inflow to model MODSEEP. A description of ARM appears in Section 3.2.1. After a verification phase involving a channel in Mortandad Canyon, MUDSEEP was applied to the study reach which began at Acid Canyon, continued along Pueblo Canyon and entered lower Los Alamos Canyon (Figure 4.24).

\subsubsection{Data Requirements}

Several field characteristics are required for the in-stream hydrodynamic modeling: a) channel geometry, b) bed slope, c) Manning roughness coefficient, and d) seepage velocity. Table 4.25 is a summary of the cross-sectional information used in this study.

Channel Geometry

The $13.77-\mathrm{km}$ study reach is described by 39 computational cross sections which are described at nodel points. For the most part, data from a field 


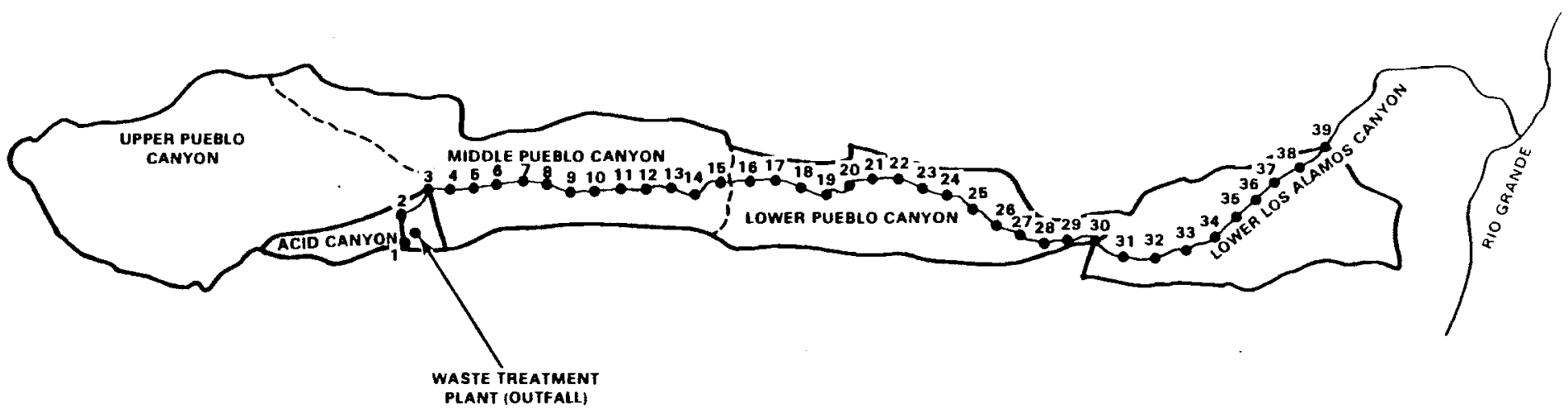

FIGURE 4.24. Segments Used for Application of MODSEEP arid TOUAM 
TABLE 4.25. Channel Information for Acid-Pueblo-Lower Los Alamos Canyon

\begin{tabular}{|c|c|c|c|c|}
\hline Node & $\begin{array}{c}\text { Bed } \\
\text { Elevation (m) } \\
\end{array}$ & 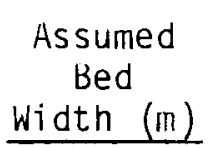 & $\begin{array}{l}\text { Downstream } \\
\text { Segment Length } \\
(\mathrm{m})\end{array}$ & $\begin{array}{c}\text { Slope } \\
\text { of } \begin{array}{c}\text { Downstream } \\
\text { Segment }\end{array} \\
\end{array}$ \\
\hline 1 & 2212.9 & 8.50 & 350 & 0.1550 \\
\hline 2 & 2158.6 & 8.50 & 320 & 0.1180 \\
\hline 3 & 2120.8 & 8.50 & 367.5 & 0.0315 \\
\hline 4 & 2109.2 & 8.50 & 367.5 & 0.0357 \\
\hline 5 & 2096.1 & 8.50 & 367.5 & 0.0365 \\
\hline 6 & 2082.7 & 8.50 & 367.5 & 0.0406 \\
\hline 7 & 2067.8 & 8.50 & 367.5 & 0.0257 \\
\hline 8 & 2058.3 & 8.50 & 367.5 & 0.0398 \\
\hline 9 & 2043.7 & 8.50 & 367.5 & 0.0299 \\
\hline 10 & 2032.7 & 8.50 & 367.5 & 0.0191 \\
\hline 11 & 2025.7 & 5.80 & 367.5 & 0.0182 \\
\hline 12 & 2019.0 & 5.80 & 367.5 & 0.0133 \\
\hline 13 & 2014.1 & 5.80 & 367.5 & 0.0133 \\
\hline 14 & 2009.3 & 5.80 & 367.5 & 0.0124 \\
\hline 15 & 2004.7 & 5.80 & 367.5 & 0.0124 \\
\hline 16 & 2000.1 & 5.80 & 367.5 & 0.0124 \\
\hline 17 & 1995.5 & 16.00 & 367.5 & 0.0124 \\
\hline 18 & 1991.0 & 15.20 & 367.5 & 0.0141 \\
\hline 19 & 1985.8 & 15.00 & 367.5 & 0.0124 \\
\hline 20 & 1981.2 & 15.00 & 367.5 & 0.0133 \\
\hline 21 & 1976.3 & 12.19 & 367.5 & 0.0174 \\
\hline 22 & 1969.9 & 30.00 & 367.5 & 0.0191 \\
\hline 23 & 1962.9 & 30.00 & 367.5 & 0.0182 \\
\hline 24 & 1956.2 & 30.00 & 366.7 & 0.0207 \\
\hline 25 & 1948.6 & 25.00 & 366.7 & 0.0149 \\
\hline 26 & 1943.1 & 7.90 & 366.7 & 0.0216 \\
\hline 27 & 1935.2 & 7.90 & 366.7 & 0.0232 \\
\hline 28 & 1926.7 & 19.81 & 366.7 & 0.0158 \\
\hline 29 & 1920.1 & 10.67 & 245.0 & 0.0398 \\
\hline 30 & 1911.1 & 10.67 & 366.7 & 0.0482 \\
\hline 31 & 1893.4 & 7.00 & 366.7 & 0.0823 \\
\hline 32 & 1863.3 & 7.00 & 366.7 & 0.0773 \\
\hline 33 & 1834.9 & 7.00 & 366.7 & 0.0549 \\
\hline 34 & 1814.8 & 7.00 & 366.7 & 0.0449 \\
\hline 35 & 1798.3 & 7.00 & 366.7 & 0.0382 \\
\hline 36 & 1784.3 & 7.00 & 366.7 & 0.0366 \\
\hline 37 & 1770.9 & 7.00 & 366.7 & 0.0249 \\
\hline 38 & 1761.8 & 7.00 & 366.4 & 0.0251 \\
\hline 39 & 1752.6 & & & \\
\hline
\end{tabular}


survey of the Los Alamos Canyon watershed provided the basis for the model representation of these cross sections. Where information from the field survey was inadequate, U.S. Geological survey (USGS) topographic maps supplied the necessary data to construct the channel geometry. Because of the crude resolution of these topographic maps, it was preferred to repeat cross sections based on the field survey wherever applicable and use the topographic maps sparingly.

The hydrodynamic model, INDSEEP, requires channel geometry to be represented by widths at various depths. In general, this approximation is satisfactory, the exception being that braided channels described in this manner cause the wetted perimeter calculation to be less accurate. Two of the field-survey cross sections exhibit minor braiding. In the worst of these two cases, the effect of using depth-width data is a 0.03 m reduction in flow depth which is well within the accuracy limits desired by this study. The channel geometry data for each cross section can be found in Appendix $A$.

Bed Slope

All bed slopes were calculated from data taken from USGS topographic maps and are presented in Table 4.25 .

Manning Roughness Coefficient

The in-stream hydrodynamic model, MODSEEP, uses the Manning resistance equation in its formulation. Available information on the study reach was not sufficient for a calibration of the roughness coefficient, which is required by the Manning equation. Therefore, an indirect determination of the roughness coefficient was performed based on three different techniques: 1) similarity, 2) composite calculation, and 3) visual comparison.

Similarity. Mortandad Canyon lies $1.2 \mathrm{~km}$ south of Los Alamos Canyon, in the same geologic formation and is subject to similar climatic history. An earlier study of Mortandad Canyon (Unishi, Whelan, and Skaggs 1982) calibrated a roughness coefficient, $n=0.045$. Because of the similarity of the two canyons, it would be reasonable to expect the roughness coefficient for Los Alamos Canyon to be near the Mortandad Canyon values. 
Composite Calculation. Chow (1959) developed a method by which various characteristics of a channel could be interpreted and quantified as separate contributions to an overall or composite roughness coefficient. Among the characteristics considered were surface irregularities, variations in the channel cross section, obstructions, vegetation, flow conditions, and channel meandering. Using this technique, a range from $n=0.04$ to $n=0.05$ was computed for Los Alamos Canyon.

Visual Comparison. The U.S. Geological Survey has published a photographic catalog of natural channels with known roughness coefficients (Barnes 1967). Those channels which closely resembled the Los Alamos channels were found to have roughness coefficients from 0.035 to 0.045 .

Based on these three approaches to roughness coefficient determination, a value of $n=0.04$ was used throughout the study reach. Undoubtedly, $a$ spatially varying roughness coefficient is the actual case. Unfortunately, the limited amount of field information does not justify such detail.

\section{Seepage Velocity}

The representation of the seepage mechanism in MODSEEP is a simplified approach which assumes that a constant water flux per wetted surface area occurs. This parameter has been labeled "seepage velocity." The seepage velocity used in this study is taken from an earlier study of Mortandad Canyon (Onishi, whelan, and Skaggs 1982). As mentioned above, Mortandad Canyon is similar in many respects to the study reach in the Los Alamos drainage basin. In the absence of other means of determining the seepage velocity, this was the basis for selection. Table 4.26 is a comparison of field test seepage rates with the seepage velocity used in this study. Although these two parameters (field and model rates) are not exactly equivalent because of the different environmental conditions they are applied under, the magnitudes should be similar.

\section{Discretization}

The method of finite differences is the artifice which MODSEEP relies on to represent the derivatives in the governing equations. The resolution of 
TABLE 4.26. Comparison of Model and Field Seepage Velocities

Source

MOUSEEP

Mortandad Canyon, $Q=0.0185 \mathrm{~m}^{3} / \mathrm{s}$

(Onishi et al. 1982)

Mortandad Canyon, $Q=0.010 \mathrm{~m}^{3} / \mathrm{s}$

(Onishi et al. 1982)

Mortandad Canyon, $\mathrm{H}=0.75 \mathrm{ft}(\mathrm{a})$

(Abrahams, Weir, and Purtymun 1961)

Acid-Pueblo Canyon, $Q=0.06 \mathrm{~m}^{3} / \mathrm{s}$ (LANL 1981)
Seepage Velocity or Infiltration Rate

Seepage velocity,

$2.35 \times 10^{-5} \mathrm{~m} / \mathrm{s}$

$7.8 \times 10^{-6}-1.10 \times 10^{-5} \mathrm{~m}^{3} / \mathrm{s} / \mathrm{m}$

$1.2 \times 10^{-5}-3.4 \times 10^{-5} \mathrm{~m}^{3} / \mathrm{s} / \mathrm{m}$

Infiltration rate,
$1.132 \times 10^{-5} \mathrm{~m} / \mathrm{s}$

$5 \times 10^{-6} \mathrm{~m}^{3} / \mathrm{s} / \mathrm{m}$

(a) The parameter $H$ refers to a constant head.

(b) Second day test.

the discrete network of nodes which represent the continuous problem domain is determined by the spacing of these nodes. The temporal and spatial increments in this study were selected to balance computational effort with accuracy considerations. As MUUSEEP does not require constant segment lengths, there are 38 segments of six different lengths to represent the study reach. The longest segment is 367.5 meters long while the shortest segment is 245 meters long. The time increment is invariant at 100 seconds.

\subsubsection{Model Testing}

Prior to application on the Acid-Pueblo-Los Alamos Canyon study reach, the in-stream hydrodynamic model, MODSEEP, was tested on two channels in the Los Alamos area: Mortandad Canyon and upper Los Alamos Canyon.

The Mortandad Canyon test was performed to verify the seepage and lateral inflow routines of the MODSEEP model. Verification of the flood wave travel and attenuation mechanisms in MOUSEEP have appeared in the literature (Ponce 1978). The present test was a replication of a flow event in Mortandad Canyon 
which is described in a study by Onishi, whelan, and Skaggs (1982). Using the parameters and boundary conditions from this earlier study, MODSEEP produced a peak discharge which was in excellent agreement with the listed peak discharge.

In the second test, a few numerical experiments were performed to evaluate the sensitivity of the seepage velocity used in MODSEEP. A channel in upper Los Alamos Canyon was the site simulated using a synthesized flow event. Results from these experiments indicate that the calculated discharges can be expected to be quite sensitive to the seepage velocity selected.

\subsubsection{Scenario}

In this study, $13.77 \mathrm{~km}$ of channel are represented by 38 computational segments. Two segments are in a $0.67 \mathrm{~km}$ section of Acid Canyon, 27 segments are in a $9.80 \mathrm{~km}$ section of Pueblo Canyon, and 9 segments are in a $3.30 \mathrm{~km}$ section of lower Los Alamos Canyon (Figure 4.24). The assumption of this study is that localized runoff in Acid and Pueblo Canyons enters the initially dry stream channel and flows down lower Los Alamos Canyon to the Bayo Canyon confluence, where the simulation ends. Flow contribution from upper Los Alamos Canyon is assumed to be zero. A runoff event which possibly corresponds to the 50-year flood return period is simulated.

\subsubsection{Results}

The peak discharge just upstream of the confluence of Bayo and Los Alamos Canyons from the in-stream hydrodynamic modeling for the 50-yr flood return interval was $23.0 \mathrm{~m}^{3} / \mathrm{s}$. Hydrographs of the 50 -year flood event simulated by MODSEEP appear in Figures 4.25 through 4.27. Figure 4.25 is the upstream boundary condition at the head of Acid Canyon. Discharge magnitudes are extremely small at this point due to the relatively small runoff area which contributes to streamflow. The hydrograph at the confluence of Pueblo and Los Alamos Canyons is presented in Figure 4.26. This location will have the largest discharges because the entire runoff area used in this study lies upstream of this confluence. Discharges in lower Los Alamos Canyon will be slightly smaller due to flood wave attenuation and seepage through the channel bed (Figure 4.27). 


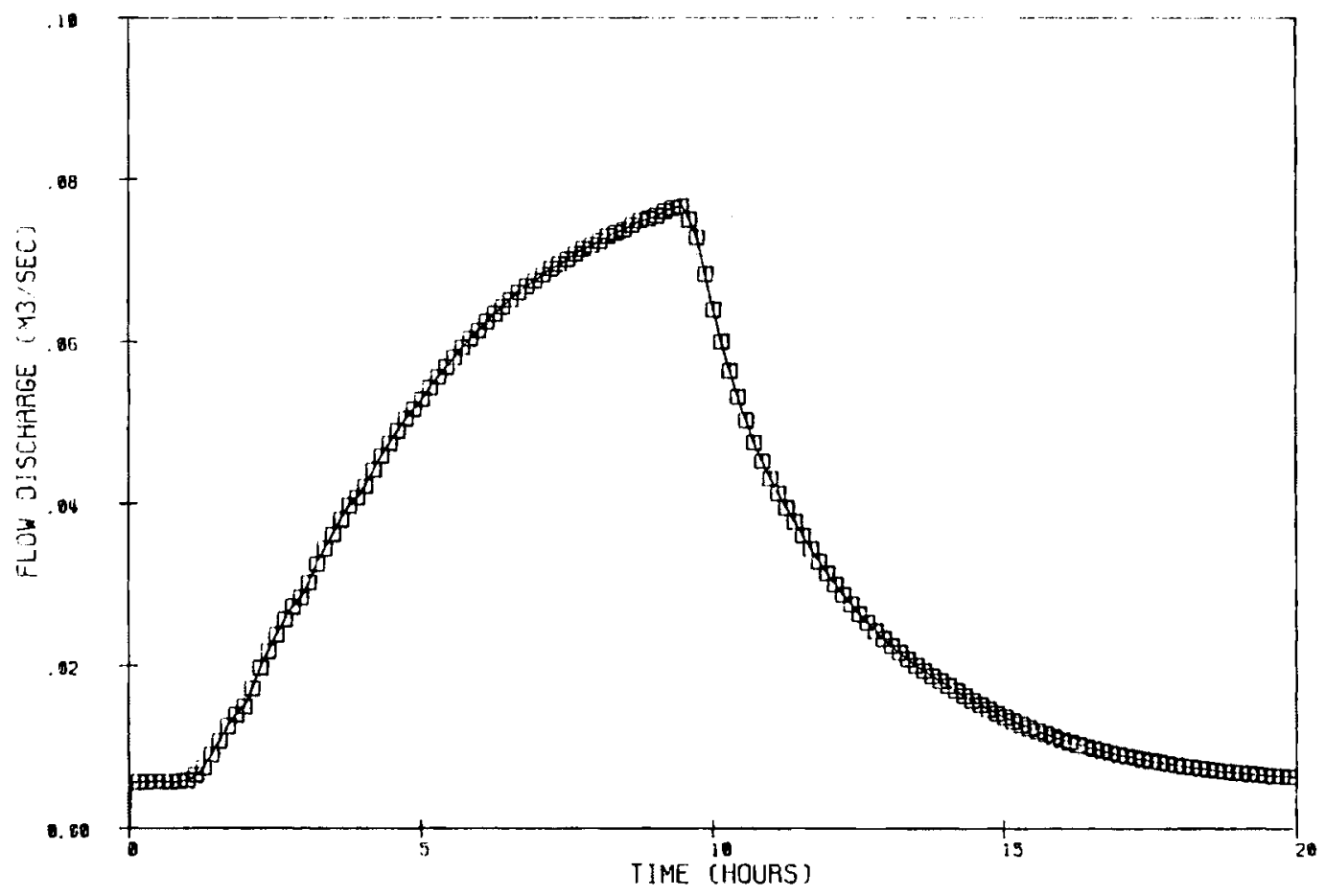

FIGURE 4.25. Head of Acid Canyon - 50 Year Flood Event

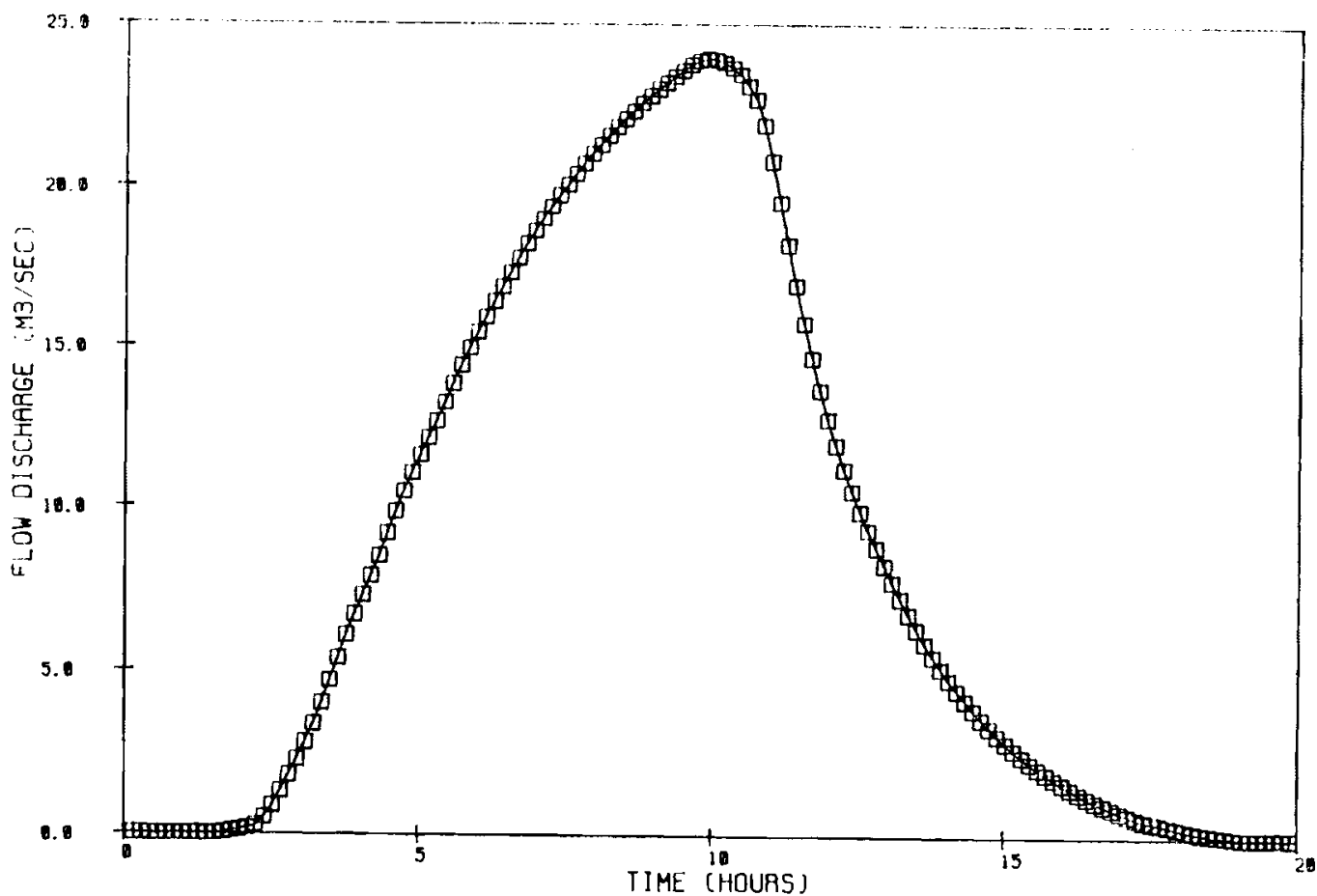

FIGURE 4.26. Confluence of Pueblo-Los Alamo Canyon - 50-Year Flood Event

4.74 


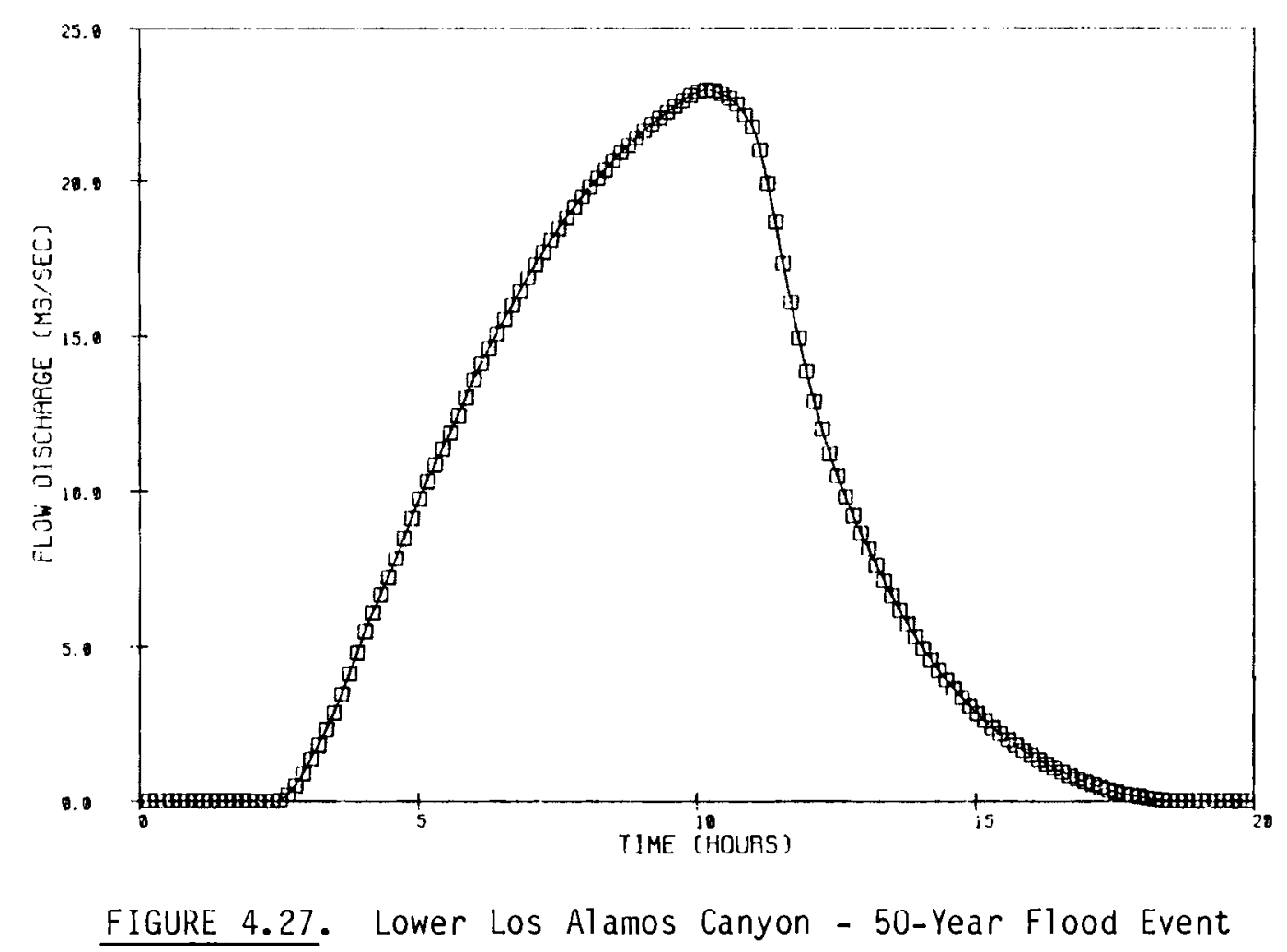

\subsection{IN-STREAM CONTAMINANT TRANSPORT MODELING}

This section describes the in-stream sediment contaminant transport modeling. It presents the procedures for defining the input parameters for TODAM and the results of the sediment-contaminant transport modeing scenario.

\subsubsection{Definition of Parameters}

Most of the information required by TODAM was available in the literature. A great deal of information pertaining to this area in New Mexico was provided by Onishi, whelan, and Skaggs (1982). They simulate the transport and fate of radionuclides (239pu) in the nearby Mortandad Canyon watershed several kilometers south of the Los Alamos watershed. The following paragraphs describe the input parameters employed in TODAM as they pertain to the Los Alamos site and the methdology used in defining them.

\section{Porosity}

Very litle information has been documented regarding the porosity of soils in the Los Alamos area. Abrahams et al. (1961) reported that "measurements of 
the rate and amount of water movement and of moisture content of the soil and tuff, both under natural conditions and in controlled infiltration experiments were made as an essential part of studies of radioactive substances originating from liquid wastes or from leachable radioactive solids. These measurements were made as part of the program with the Los Alamos Scientific Laboratory(a) - . Twenty-three test holes were drilled on Frijoles Mesa (b) and moisture measurements were made in the spring, summer, and fall of 1960 to study natural infiltration in the soil and tuff." From these measurements, the average total porosity at a depth of $30 \mathrm{~cm}$ and $76 \mathrm{~cm}$ was $51.3 \%$ and $46.9 \%$, repectively. The average weighted porosity is, therefore, $50 \%$. A bed porosity of $50 \%$ was assumed for the modeling scenario.

Specific Gravity

It was assumed that A-P and DP-LA Canyons represent alluvial streams, since $98 \%$ of their river beds are composed of sand. The specific gravity for sediment was, therefore, selected as 2.65 (Vanoni 1975).

Sediment Size Distributions

TODAM computes the migration and fate of three sediment sizes or types. Sand, silt, and clay represent the three sediment sizes used in this modeling effort. The noncohesive sediments are represented by sand $(>0.062 \mathrm{~mm}$ in diameter) and the cohesive sediments are represented by silt and clay (<0.062 mm in diameter) (Vanoni 1975). Silts are generally represented by sieve sizes between $0.062 \mathrm{~mm}$ and $0.004 \mathrm{~mm}$, while clays are usually represented by sieve sizes between $0.004 \mathrm{~mm}$ and $0.00024 \mathrm{~mm}$. Included in this section are the sediment sizes used in the modeling scenario for suspended and bed sediments.

The sediment size distributions at various locations were presented previously in Figures 4.6 through 4.10 and in Tables 4.2 tinrough 4.6. The actual loations where these samples were taken are presented in Figure 4.5 . Also, Table 4.27 presents the median diameters of bed sediment at each node as

(a) Now known as the Los Alamos National Laboratory.

(b) Four kilometers south of Los Alamos Canyon. 
TABLE 4.27. Sediment Information for Acid-Pueblo-Lower Los Alamos Canyon

\begin{tabular}{|c|c|c|c|c|c|c|}
\hline Segment & $\begin{array}{c}\text { Median } \\
\text { Sediment } \\
\text { Diameter, mm } \\
\end{array}$ & $\begin{array}{c}\text { Sand } \\
\text { Diameter, } \\
\text { mm }\end{array}$ & $\begin{array}{l}\% \text { Sand } \\
\text { in Bed } \\
\end{array}$ & $\begin{array}{c}\% \text { Silt }(\mathrm{a}) \\
\text { in Bed } \\
\end{array}$ & $\begin{array}{c}\% \text { Clay }(a) \\
\text { in Bed }\end{array}$ & $\begin{array}{l}\text { Sand Fall (a) } \\
\text { Velocity, m/s }\end{array}$ \\
\hline 1 & 1.19 & 1.30 & 99.50 & 0.12 & 0.38 & 0.113 \\
\hline 2 & 1.14 & 1.30 & 97.00 & 0.75 & 2.25 & 0.113 \\
\hline 3 & 1.01 & 1.17 & 98.50 & 0.37 & 1.13 & 0.106 \\
\hline 4 & 1.01 & 1.17 & 98.50 & 0.37 & 1.13 & 0.106 \\
\hline 5 & 1.01 & 1.17 & 98.50 & 0.37 & 1.13 & 0.106 \\
\hline 6 & 1.08 & 1.29 & 97.00 & 0.75 & 2.25 & 0.112 \\
\hline 7 & 1.08 & 1.29 & 97.00 & 0.75 & 2.25 & 0.112 \\
\hline 8 & 1.08 & 1.29 & 97.00 & 0.75 & 2.25 & 0.112 \\
\hline 9 & 1.08 & 1.29 & 97.00 & 0.75 & 2.25 & 0.112 \\
\hline 10 & 1.08 & 1.29 & 97.00 & 0.75 & 2.25 & 0.112 \\
\hline 11 & 1.08 & 1.29 & 97.00 & 0.75 & 2.25 & 0.112 \\
\hline 12 & 0.80 & 1.01 & 97.00 & 0.75 & 2.25 & 0.097 \\
\hline 13 & 0.80 & 1.01 & 97.00 & 0.75 & 2.25 & 0.097 \\
\hline 14 & 0.80 & 1.01 & 97.00 & 0.75 & 2.25 & 0.097 \\
\hline 15 & 0.80 & 1.01 & 97.00 & 0.75 & 2.25 & 0.097 \\
\hline 16 & 0.80 & 1.01 & 97.00 & 0.75 & 2.25 & 0.097 \\
\hline 17 & 0.80 & 1.01 & 97.00 & 0.75 & 2.25 & 0.097 \\
\hline 18 & 0.80 & 1.01 & 97.00 & 0.75 & 2.25 & 0.097 \\
\hline 19 & 0.60 & 0.76 & 89.00 & 2.75 & 8.25 & 0.081 \\
\hline 20 & 0.60 & 0.76 & 89.00 & 2.75 & 8.25 & 0.081 \\
\hline 21 & 0.60 & 0.76 & 89.00 & 2.75 & 8.25 & 0.081 \\
\hline 22 & 0.60 & 0.76 & 89.00 & 2.75 & 8.25 & 0.081 \\
\hline 23 & 0.60 & 0.76 & 89.00 & 2.75 & 8.25 & 0.081 \\
\hline 24 & 0.60 & 0.76 & 89.00 & 2.75 & 8.25 & 0.081 \\
\hline 25 & 0.60 & 0.76 & 89.00 & 2.75 & 8.25 & 0.081 \\
\hline 26 & 0.77 & 0.88 & 97.20 & 0.70 & 2.11 & 0.089 \\
\hline 27 & 0.77 & 0.88 & 97.20 & 0.70 & 2.11 & 0.089 \\
\hline 28 & 0.77 & 0.88 & 97.20 & 0.70 & 2.11 & 0.089 \\
\hline 29 & 0.77 & 0.88 & 97.20 & 0.70 & 2.11 & 0.089 \\
\hline 30 & 0.77 & 0.88 & 97.20 & 0.70 & 2.11 & 0.089 \\
\hline 31 & 0.77 & 0.88 & 97.20 & 0.70 & 2.11 & 0.089 \\
\hline 32 & 0.77 & 0.88 & 97.20 & 0.70 & 2.11 & 0.089 \\
\hline 33 & 0.77 & 0.88 & 97.20 & 0.70 & 2.11 & 0.089 \\
\hline 34 & 0.43 & 0.56 & 96.50 & 0.87 & 2.63 & 0.066 \\
\hline 35 & 0.43 & 0.56 & 96.50 & 0.87 & 2.63 & 0.066 \\
\hline 36 & 0.43 & 0.56 & 96.50 & 0.87 & 2.63 & 0.066 \\
\hline 37 & 0.43 & 0.56 & 96.50 & 0.87 & 2.63 & 0.066 \\
\hline 38 & 1.70 & $1.70(0)$ & 98.00 & 0.50 & 1.50 & 0.131 \\
\hline
\end{tabular}

(a) Cohesive sediment inventories were divided as $75 \%$ clay and $25 \%$ silt (Onishi, Whelan, and Skaggs 1982).

(b) Based on Ruby's Formula (Vanoni 1975).

(c) Diameter of sand was assumed to equal the median diameter of the sediment sample. 
well as the representative diameters of the bed sediment for sand, silt, and clay at each node. The median diameter and the representative diameters for sand, silt and clay were computed as follows.

Since the movement of silt and clay size fractions are simulated by TUDAM, only one representative bed sand size is allowed for the entire Los Alamos area. The sand size assumed for the modeling scenario was $0.76 \mathrm{~mm}$. This size represents the sand size in lower Pueblo Canyon where the majority of $239 \mathrm{Pu}$ inventory exists. This size fraction is also equal to or smaller than 90 of the sand sizes comprising the Acid-Pueblo-Los Alamos Canyon bed. By simulating the movement of the smaller size, the contaminated sediment has a better chance to be entrained into the flow and migrate into lower Los Alamos Canyon. This becomes very important when considering the containinant levels at the head of Acid Canyon (Section 4.1.2). It should be noted that the sand sediment size of $0.76 \mathrm{~mm}$ is very close to the upper limit for which Toffaleti's sediment routing formulation is applicable (Toffaleti 1968).

Median Bed Sediment Size

The median bed sediment size $\left(D_{50}\right)$ was obtained from the sediment size fraction distributions presented in Figures 4.6 through 4.10 . In the case where $D_{50}>2 \mathrm{~mm}, D_{50}$ was assumed to equal $2 \mathrm{~mm}$. This represents a conservative assumption because as the size fraction decreases there is an increase in the probability for sediment entrainment by channel flows.

Representative Bed Diameter for Sand

To understand the size of the sand particles comprising the bed in AcidPueblo-Los Alamos Canyon, representative bed sediment sizes for sand at various locations in the channels were computed based upon the information presented in Tables 4.2 through 4.6 and in Figures 4.6 through 4.10 . The representative bed sediment size for sand at various locations was calculated as follows:

1) The geometric mean of the sizes presented for each sieve size greater than $0.062 \mathrm{~mm}$ was computed.

2) The size for each classification was computed by weighting the geometric means according to the percent sediment in each size fraction. 
3) If the median diameter was greater than the representative sediment size for each sand, then the representative sand size was set equal to the median sediment diameter. This was done because a large group of sediment has sizes greater than $2 \mathrm{~mm}$. The upper bound to these sizes was, of course, unknown. By equating the representative sand size with the median diameter, these larger sizes in some way are accounted for. They should be accounted for, as in some cases, they represent more than $65 \%$ of the sample.

These results are presented in Table 4.28 .

Representative Bed Diameter for Silt and Clay

The cohesive sizes were computed in a manner very similar to that outlined for the representative bed diameter for sand. These sizes at various locations were based upon the information presented in Tables 4.2 through 4.6 and Figures 4.6 through 4.10. The cohesive sediment diameters were computed by assuming the geometric mean of the size classification for silt and clay as referred by Vanoni (1975). The representative bed diameter for silt and clay were computed as $0.016 \mathrm{~mm}$ and $0.001 \mathrm{~mm}$, respectively. The distribution of cohesive sediment inventories was divided as $75 \%$ clay and $25 \%$ silt (Onishi, Whelan, and Skaggs 1982). For more information, refer to the following sections.

\section{Overland Sediment Distributions}

Data presented by Purtymun (1974) revealed that 58\% of the weathered overland tuff on DP Canyon was composed of sand, while $42 \%$ was composed of silt and clay. This information is presented in Table 4.6. Purtymun also reported that "the silt and clay are largely montmorillonite and illite which are weathering products of tuff ..." These clay minerals are believed to be responsible for the effectiveness of the Los Alamos soil in removing plutonium from waste solutions." Based on these observations it was assumed that 75\% of the soil composite was clay and that $25 \%$ was silt. The sediment distribution between sand, silt, and clay at the stream's edge was assumed as 
TABLE 4.28. Initial Bed Contamination Levels

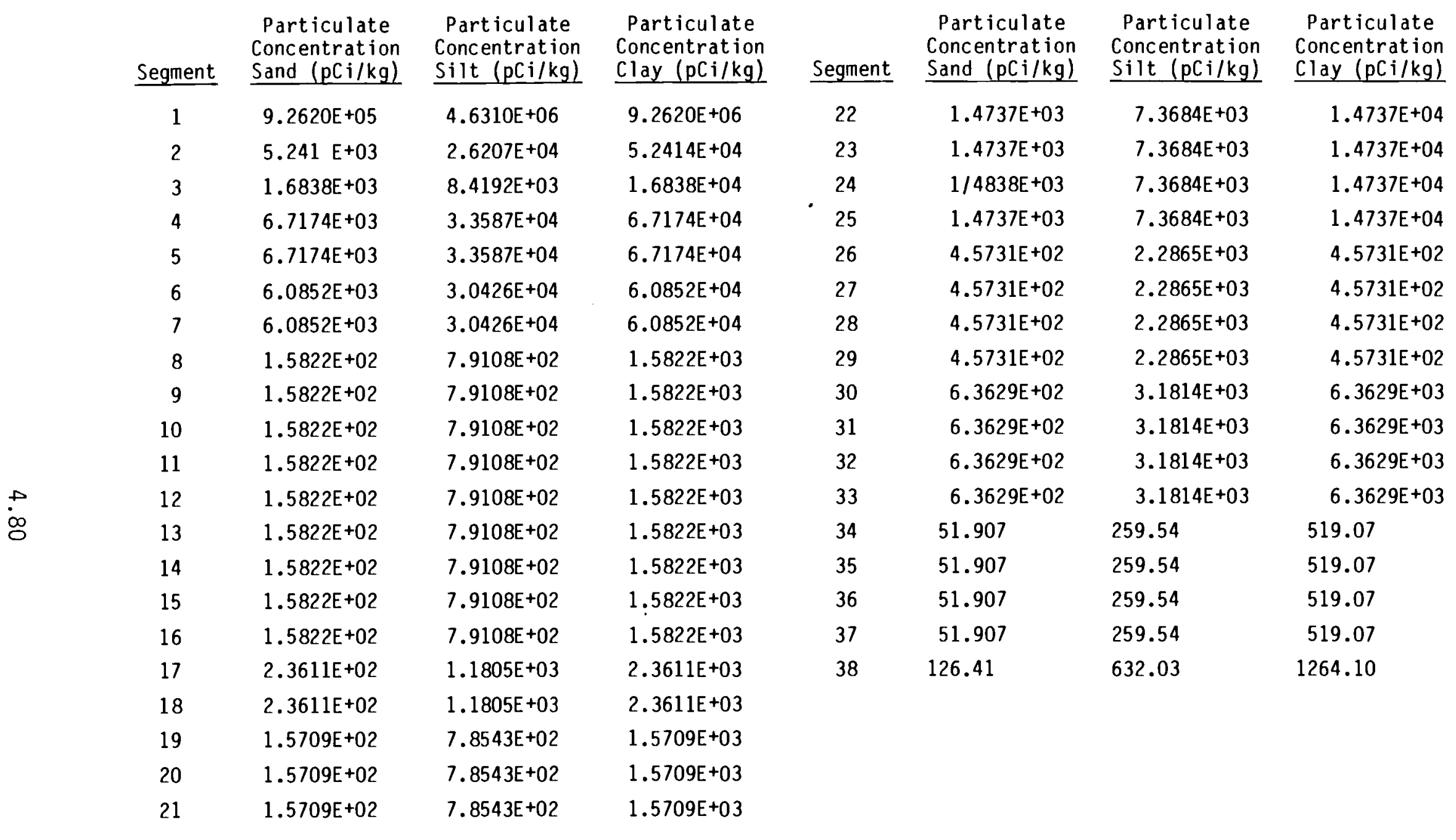




$$
\begin{aligned}
\text { Sand : } & (0.58)(100 \%)=58.0 \% \\
\text { Silt: }(0.25)(0.42)(100 \%) & =10.5 \% \simeq 10 \% \\
\text { Clay: } \quad(0.75)(0.42)(100 \%) & =31.5 \% \simeq 32 \%
\end{aligned}
$$

Due to its size, DP Canyon was also modeled as an overland segment. The percent finer sediment size distribution curves for weathered tuff and bed and suspended sediments for DP Canyon are presented in Figure 4.10. The figure reveals that the median sediment size for the weathered tuff and bed and suspended sediments are $0.115 \mathrm{~mm}, 0.88 \mathrm{~mm}$ and $0.115 \mathrm{~mm}$, respectively. The weathered tuff and the suspended sediment have similar sediment size distributions while the bed sediments appear unusually large. Based on this information, the sediment size distribuion was the same as that assumed on all other overland segments with the sand, silt, and clay distributions represented by Equations (4.1), (4.2) and (4.3), respectively.

\section{Fall Velocities}

The fall velocities of the three sediment types were calculated according to their representative diameter sizes. Ruby's formula as outlined by Vanoni (1975) was employed for calculating the fall velocities. The fall velocities of the sand size are presented in Table 4.27. The fall velocities used for silt and clay in the modeling scenario were defined as $1.88 \times 10^{-4} \mathrm{~m} / \mathrm{s}$ and $7.32 \times 10^{-7} \mathrm{~m} / \mathrm{s}$, respectively.

\section{Erodibility Coefficient and Critical Stresses Associated with}

\section{Cohesive Sediments}

The river bed is mainly composed of sand, which indicates that silt and clay tend to be carried through the system. Typical bed shear stresses (corresponding to peak discharges of $0.3 \mathrm{~m}^{3} / \mathrm{s}$ ) as provided by onishi, Whelan, and Skaggs (1982) ranged from $<1 \mathrm{~kg} / \mathrm{m}^{2}$ to $20 \mathrm{~kg} / \mathrm{m}^{2}$. The critical shear stresses associated with deposition for silt and clay were estimated to be $0.01 \mathrm{~kg} / \mathrm{m}^{2}$ and $3.3 \times 10^{-3} \mathrm{~kg} / \mathrm{m}^{2}$, respectively (Onishi, Whelan, and Skaggs 1982). The critical shear stresses associated with scour and the erodibility coeficient were determined from the calibration process of TODAM on the nearby Mortandad Canyon watershed as presented by Onishi, Whelan, and Skaggs (1982). These were 
determined through the calibration process to produce an appropriate amount of cohesive soil to be scoured from the bed. Through calibration, the silt and clay have a critical shear stress of erosion of $7 \mathrm{~kg} / \mathrm{m}^{2}$ and $10 \mathrm{~kg} / \mathrm{m}^{2}$, respectively, and an erodibility coefficient was selected as $0.2 \mathrm{~kg} / \mathrm{m}^{2} /$ day. With these values, the bulk of the silt and clay will be carried through the system.

Longitudinal Dispersion Coefficient

Several formulations have been proposed and several experiments have been performed for selecting the longitudinal dispersion coefficient $E_{X}$. Because of lack of data on A-P and DP-LA Canyons, the dispersion coefficient was assumed as equaling that of the value used by Onishi, Whelan, and Skaggs (1982) for nearby Mortandaad Canyon. It was computed from a formulation as presented by Fischer (1967):

$$
E_{x}=\frac{0.011 U^{2} b^{2}}{d U^{\star}} \simeq \frac{0.011 Q^{2}}{d^{3} U^{*}}
$$

where

$E_{X}=$ longitudinal dispersion coefficient $\left(\mathrm{m}^{2} / \mathrm{s}\right)$,

$Q=$ flow discharge $\left(\mathrm{m}^{3} / \mathrm{s}\right)$,

$d=\operatorname{deptn}$ of flow $(m)$, and

$U *$ = shear velocity $(\mathrm{m} / \mathrm{s})$.

Typical values for Mortandad Canyon were used in determining $E_{x}$, and $E_{x}$ was approximated as equaling $0.1 \mathrm{~m}^{2} / \mathrm{s}$. With this value, the longitudinal dispersion process does not dominate the in-stream advection process. Variations in $E_{x}$ produced little changes in the results, thereby confirming the dominance of the advection phenomenon.

Distribution Coefficient $\left(K d_{j}\right)$ of 230 Pu with Sediment

As presented by Onishi, Whelan, and Skaggs (1982), the ratio of distribution coefficient (Kd) values for sand, silt, and clay was assumed as:

$$
(K d)_{\text {sand }}:(K d)_{\text {silt }}:(K d)_{\text {clay }}=1: 5: 10
$$


These values were based upon the previous investigations of Ecker et al. (1979) and Onishi et al. (1979). Hakonson et al. (1976) provided runoff sample concentrations of ${ }^{239} \mathrm{Pu}$. From these data, the $\mathrm{Kd}$ value associated with the bulk sediment was estimated as $12 \mathrm{~m}^{3} / \mathrm{kg}$.

Data presented by Purtymun (1974) revealed that 35\% of the suspended sediment in DP canyon was silt and clay, while $65 \%$ was sand. Purtymun also reported that "the silt and clay are largely montmorillonite and illite which are weathering products of tuff. - These clay minerals are believed to be responsible for the effectiveness of the Los $\mathrm{Alamos}$ soil in removing plutonium from waste solutions." Based on these observations, it was assumed that $75 \%$ of the cohesive soil composite was clay, while $25 \%$ was assumed silt. The suspended sediment composition could, therefore, be expressed as:

$$
\text { Sand : Silt : Clay }=0.65: 0.0875: 0.2625
$$

The bulk kd values may be expressed as

$$
(0.65)(K d)_{\text {sand }}+(0.0875)(K d)_{\text {silt }}+(0.2625)(K d)_{c l a y}=12 \mathrm{~m}^{3} / \mathrm{kg}
$$

Combining Equations (4.6) and (4.7) and solving for the Kd values associated with sand, silt, and clay gives the following information:

$$
\begin{aligned}
& (k d)_{\text {sand }}=3.23 \mathrm{~m}^{3} / \mathrm{kg}=3 \mathrm{~m}^{3} / \mathrm{kg} \\
& (k d)_{\text {silt }} \simeq 15 \mathrm{~m}^{3} / \mathrm{kg} \\
& (k d)_{\text {clay }} \simeq 30 \mathrm{~m}^{3} / \mathrm{kg}
\end{aligned}
$$

Equations (4.8), (4.9) and (4.10) represent Kd values associated with sand, silt and clay, respectively, for which the desorption mechanism is not the main phenomenon.

Since the $\mathrm{Kd}_{\mathrm{j}}$ values for desorption are rarely known and the $\mathrm{Kd}_{\mathrm{j}}$ values for adsorption are generally known, the latter $\mathrm{Kd}_{j}$ values are usually used. In 
the case where radioactive effluent is discharged directly to the water body, this procedure appears valid. Since most of the ${ }^{239} \mathrm{Pu}$ is adsorbed onto the sediment in the stream bed already, the $\mathrm{Kd}_{j}$ values should depict the desorption phenomenon as the main mechanism. Using $\mathrm{Kd}_{j}$ values for adsorption, on the other hand, is not very effective. The $\mathrm{Kd}_{j}$ values should reflect the ability of the sediment sizes to retain the radionuclides once these nuclides have been adsorbed. Equations (4.8), (4.9) and (4.10) were modified as follows to reflect sediment retention properties:

1. Data presented by Purtymun (1974) revealed that $58 \%$ of the weathered overland tuff on DP Canyon was sand, while $42 \%$ was silt and clay. Based on this information, it can be assumed that at the stream's edge the sediment distribution between sand, silt and clay was

$$
\begin{aligned}
\text { Sand }: & (0.58)(100 \%)=58 \% \\
\text { Silt: }(0.25)(0.42)(100 \%) & =10.5 \simeq 10 \% \\
\text { Clay: }(0.75)(0.42)(100 \%) & =31.5 \simeq 32 \%
\end{aligned}
$$

By combining Equations (4.8) through (4.13), the ratios of the radionuclides associated with sand, silt and clay at stream's edge can be estimated as

Sand : Silt : Clay $=(0.58)(3):(0.10)(15):(0.32)(30)$

The percentage of radionuclides associated with sand, silt and clay are $13 \%, 12 \%$ and $75 \%$, respectively.

2. Radionuclides have more of an affinity for smaller sediment sizes than for larger ones. As such, it was assumed that ${ }^{239} \mathrm{Pu}$ already adsorbed by smaller-sized particles could not easily be adsorbed by larger-sized particles. In order to acount for this, the $\mathrm{Kd}_{\mathrm{j}}$ values were adjusted as follows: 


$$
\begin{aligned}
& (\mathrm{Kd})_{\text {sand }}=\left(3 \mathrm{~m}^{3} / \mathrm{kg}\right)(0.13)=0.39 \mathrm{~m}^{3} / \mathrm{kg} \\
& (\mathrm{Kd})_{\text {silt }}=\left(15 \mathrm{~m}^{3} / \mathrm{kg}\right)(0.13+0.12)=3.75 \mathrm{~m}^{3} / \mathrm{kg} \\
& (\mathrm{Kd})_{\text {clay }}=\left(30 \mathrm{~m}^{3} / \mathrm{kg}\right)(0.13+0.12+0.75)=30 \mathrm{~m}^{3} / \mathrm{kg}
\end{aligned}
$$

Physically, these computations state that the smaller-sized particles have a greater opportunity to adsorb ${ }^{239} \mathrm{Pu}$ from the larger-sized particles than do the larger-sized particles from the smaller ones.

Based on Equations (4.15), (4.16) and (4.17), the $\mathrm{Kd}_{\mathrm{j}}$ values empoyed on the Los Alamos modeing site were set at $0.39 \mathrm{~m}^{3} / \mathrm{kg}$ for sand, $3.75 \mathrm{~m}^{3} / \mathrm{kg}$ for silt, and $30.00 \mathrm{~m}^{3} / \mathrm{kg}$ for clay.

\section{Iransfer Rates $\left(K_{j}\right.$ and $\left.K b_{j}\right)$ of Radionuclides}

The transfer rate (reciprocal of time) expresses the time required to reach an equilibrium condition between particulate (radionuclides adsorbed to sediment) and dissolved phases as determined by the $\mathrm{Kd}_{\mathrm{j}}$ values. The transfer rate $k_{j}$ relates particulate ${ }^{239} \mathrm{Pu}$ concentrations associated with suspended sediments with dissolved concentrations, while the transfer rate $\mathrm{Kb}_{\mathrm{j}}$ relates particulate ${ }^{239} \mathrm{Pu}$ concentrations associated with bed sediments with dissolved concentrations. According to LANL (1981), 99\% of the plutonium travels with the sediment (particulate phase), while only $\sim 1 \%$ travels in the dissolved phase. The values employed for this modeling scenario were based on the results for South Mortandad Canyon (Onishi, Whelan, and Skaggs 1982) and several short calibrating runs on A-P Canyon. The Mortandad study employed a value of $1.2 \times 10^{-6} \mathrm{~s}^{-1}$ for $K_{j}$. Kb $b_{j}$ values were not assigned in the Mortandad study. Since bed sediments do not interact with the water as much as suspended sediments, it was assumed that the transfer rates $k_{b} j$ were one order of magnitude less than that assigned to $K_{j}$. Based on the short calibrating runs on A-P Canyon the $K_{j}$ value was reduced from $1.2 \times 10^{-6} \mathrm{~s}^{-1}$ to $1.2 \times 10^{-8} \mathrm{~s}^{-1}$. $\mathrm{Kb}_{\mathrm{j}}$ was reduce from $1.2 \times 10^{-7} \mathrm{~s}^{-1}$ to $1.2 \times 10^{-9} \mathrm{~s}^{-1}$. Based on these values, the particulate phase appeared to be approximtely two orders of magnitude larger than the dissolved phase. The same $K_{j}$ and $K_{j}$ values were employed for all sediment sizes due to lack of data. 


\section{Distribution of Average ${ }^{239} \mathrm{Pu}$ Contamination for Sand, Silt, and Clay in the Bed}

The computed $\mathrm{Kd}$ values of $0.39 \mathrm{~m}^{3} / \mathrm{kg}, 3.75 \mathrm{~m}^{3} / \mathrm{kg}$, and $30.00 \mathrm{~m}^{3} / \mathrm{kg}$ for sand, silt, and clay, respectively, were based on the assumption that these values reflect the desorption mechanism much more so than the adsorption mechanism. This assumes that the contaminants are already adsorbed to bed sediments based on the $\mathrm{Kd}_{\mathrm{j}}$ distribution of

$$
K d_{1}: K d_{2}: K d_{3}=1: 5: 10
$$

Based on Equation (4.18), the average contaminant concentrations as presented in Tables 4.7 and 4.9 can be distributed between the sand, silt, and clay sediment size fractions as follows:

$$
\begin{aligned}
& \frac{K d_{1}}{K d_{2}}=\frac{C p_{1}}{C p_{2}} \\
& \frac{K d_{1}}{K d_{3}}=\frac{C p_{2}}{C p_{3}} \\
& C=\left(\%_{1}\right)\left(C p_{1}\right)+\left(\%_{2}\right)\left(C p_{2}\right)+\left(\%_{3}\right)\left(C p_{3}\right)
\end{aligned}
$$

where

$$
\begin{aligned}
\mathrm{Kd}_{1}= & \text { distribution coefficient for sand }\left(\mathrm{m}^{3} / \mathrm{kg}\right), \\
\mathrm{Kd}_{2}= & \text { distribution coefficient for silt }\left(\mathrm{m}^{3} / \mathrm{kg}\right), \\
\mathrm{Kd}_{3}= & \text { distribution coefficient for clay }\left(\mathrm{m}^{3} / \mathrm{kg}\right), \\
\frac{1}{C}= & \text { average particulate }{ }^{239} \mathrm{Pu} \text { concentration associated with sediments } \\
& (\mathrm{pCi} / \mathrm{kg}), \\
\%_{1}= & \text { percent composition of sand in bed, } \\
\%_{2}= & \text { percent composition of silt in bed, } \\
\%_{3}= & \text { percent composition of clay in bed, } \\
\mathrm{C}_{1}= & \text { particulate } 239 \mathrm{Pu} \text { concentration associated with sand }(\mathrm{pCi} / \mathrm{kg}),
\end{aligned}
$$


$C \mathrm{p}_{2}=$ particulate ${ }^{239} \mathrm{Pu}$ concentration associated with silt ( $\left.\mathrm{pCi} / \mathrm{kg}\right)$, $\mathrm{Cp}_{3}=$ particulate ${ }^{239} \mathrm{Pu}$ concentration associated with clay ( $\left.\mathrm{pCi} / \mathrm{kg}\right)$. Solving Equations (4.19), (4.20) and (4.21) for $C p_{1}, C p_{2}$ and $C p_{3}$ give

$$
\begin{aligned}
& C p_{1}=\frac{(\bar{C})\left(K d_{1}\right)}{\left(\%_{1}\right)\left(K d_{1}\right)+\left(\%_{2}\right)\left(K d_{2}\right)+\left(\%_{3}\right)\left(K d_{3}\right)} \\
& C p_{2}=\frac{(\bar{C})\left(K d_{2}\right)}{\left(\%_{1}\right)\left(K d_{1}\right)+\left(\%_{2}\right)\left(K d_{2}\right)+\left(\%_{3}\right)\left(K d_{3}\right)} \\
& C p_{3}=\frac{(C)\left(K d_{3}\right)}{\left(\%_{1}\right)\left(K d_{1}\right)+\left(\%_{2}\right)\left(K d_{2}\right)+\left(\%_{3}\right)\left(K d_{3}\right)}
\end{aligned}
$$

The average contaminant concentration values $(C)$ within the bed of the Los Alamos site are presented in Tables 4.7, 4.8, and 4.9. These values were gathered from several reports pertaining to contaminant levels in the canyons. References are included with the particular tables. Table 4.28 presents the initial longituinally distributed bed contamination levels for A-P and Los Alamos Canyons as distributed by sediment size fraction. These values were computed using Equations (4.22), (4.23), and (4.24). The particulate concentration levels for each node as presented in Table 4.28 are based upon the nearest (according to distance) average contaminant concentration level as presented in Tables $4.7,4.8$, and 4.9.

\subsubsection{Application Results}

The models ARM, MODSEEP, and TODAM were applied to Acid, Pueblo, and lower Los Alamos Canyons (a) to simulate movement of water, sediment, and $239 \mathrm{Pu}$ for a possible 50-yr flood event. The precipitation-generated flood event represented a flood event with a possible recurrence interval of 50 years. ARM provided overland flux of water and sediment at stream's edge in Acid and Pueblo Canyons. The flux of water and sediment at stream's edge was not provided by ARM in lower Los Alamos Canyon. This was done to insure that deposition of sediment and $239 \mathrm{Pu}$ in this region was maximized. MODSEEP computed the in-stream hydrodynamics (e.g., discharge, velocity, deptn, area, etc.). TODAM simulated the movement of sand, silt, clay, particulate $239 \mathrm{pu}$ 
adsorbed by sand, particulate ${ }^{239} \mathrm{Pu}$ adsorbed by silt, particulate ${ }^{239} \mathrm{Pu}$ adsorbed by clay, and dissolved ${ }^{239} \mathrm{Pu}$. In addition, TODAM simulated and recorded all temporal and spatial changes in the distribution of sand, silt, clay, and ${ }^{239} \mathrm{Pu}$ in the bed. Upper Los Alamos Canyon was not used in the application modeling scenario (except to calibrate the models). This was done to insure that deposition of sediment and ${ }^{239} \mathrm{Pu}$ in lower Los Alamos Canyon was maximized. The results are presented at three different locations: head of Acid Canyon (node 1), confluence of Pueblo Canyon and Los Alamos Canyon (node 30), and just upstream of the confluence of Los Alamos Canyon and Bayo Canyon in lower Los Alamos Canyon (node 39).

Figures $4.28,4.29$, and 4.30 present the simulated flow rates varying temporally at nodes 1, 30, and 39, respectively, for the 50-yr flood event. The discharge hydrograph presented in Figure 4.28 represents the upstream boundary conditions as provided by ARM for the in-stream modeling scenario. The peak discharges at nodes 30 and 39 are approximately 300 times larger than the peak discharge at the head of Acid Canyon (node 1). The peak discharge at node 1 is small because only $0.2 \%$ of the total overland area comprising AcidPueblo-lower Los Alamos Canyon drains into the first node. It should be noted that the peak flow at node $2\left(0.762 \mathrm{~m}^{3} / \mathrm{s}\right)$ is approximately one order of magnitude higher than at node 1. A major portion of the flow enters at the third node (entering as a point flow) where upper Pueblo Canyon drains into the channel (see Figure 4.2). The peak discharge here was $13.9 \mathrm{~m}^{3} / \mathrm{s}$. The major reason is that the lateral inflow exceeds the channel seepage. The peak discharge then proceeds to drop from a high of $23.9 \mathrm{~m}^{3} / \mathrm{s}$ at node 30 to $23.0 \mathrm{~m}^{3} / \mathrm{s}$ at node 39 (Figure 4.30). There is a drop in the peak discharge and flow volume between nodes 30 and 39 because no lateral inflow exists within this channel reach, while channel seepage continues to occur. Due to the swift movement of the flood wave between nodes 30 and 39 , only $4 \%$ of the peak is reduced due to seepage and attenuation.

(a) Lower Los Alamos Canyon as described herein only refers to the region upstream of the confluence of Los Alamos Canyon and Bayo Canyon and downstream of the confluence of Pueblo Canyon and Los Alamos Canyon. 
Figure 4.31 presents the sediment flux varying by size fraction distributed temporally at the head of Acid Canyon (node 1) for the 50-yr flood event. This figure represents the upstream boundary condition as provided by ARM. The composition of the sediment entering node 1 and at stream's edge from all overland segments is $58 \%$ sand, $10 \%$ silt, and $32 \%$ clay. For more information regarding the distribution of sediment into size fractions, refer to Section 4.4.1. Figures 4.32 and 4.33 present the sediment flux varying by size fraction distributed temporarily at nodes 30 and 39, respectively, for the 50-yr flood event. There is a large increase in the sediment flux from node 1 to node 30 as depicted by Figures 4.31 and 4.32, respectively. The two main sources attributed for the increase are lateral inflow from overland segments and bed erosion. The peak sediment discharge increases by only $13 \%$ from node 30 to node 39 (Figures 4.32 and 4.33). The sediment transport capacity for channel segments (a) 34 through 38 is larger than that for lower Pueblo

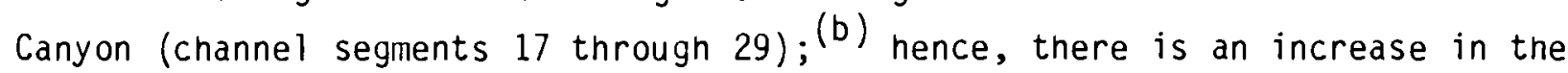
peak sediment flux from node 30 to node 39 . Because lower Pueblo Canyon is broader with a smaller gradient (average slope $\simeq 1.6 \%$ ) than channel segments 34 through 38 (average slope $\simeq 3.4 \%$ ), the sediment transport capacity is less. Even though the transport capacity in channel segments 34 through 38 is greater than in lower Pueblo Canyon, deposition in channel segments 34 through 38 is occurring. The excess sediment required for a larger sediment load and deposition in channel segments 34 through 38 is supplied from channel segments 30 through 33 through bed degradation. Lower Los Alamos Canyon can be described by two distinct regions. Channel segments $30,31,32$, and 33 represent an area which is relatively narrow with a fairly large gradient (average slope $\simeq 6.6 \%$ ), whereas channel segments 34 through 38 represent a broad, wide area (narrower than lower Pueblo Canyon, however) with a smaller gradient. The sediment at channel segments 30 through 33 is entrained into a flow with a higher sediment transport capacity than that at channel segments 34 through 38 . When the sediment migrates down to the latter area, it deposits until the sediment

(a) The number of channel segments is always one less than the number of nodes. For example, the first channel segment is bounded by nodes 1 and 2 .

(b) Given the same discharges. 


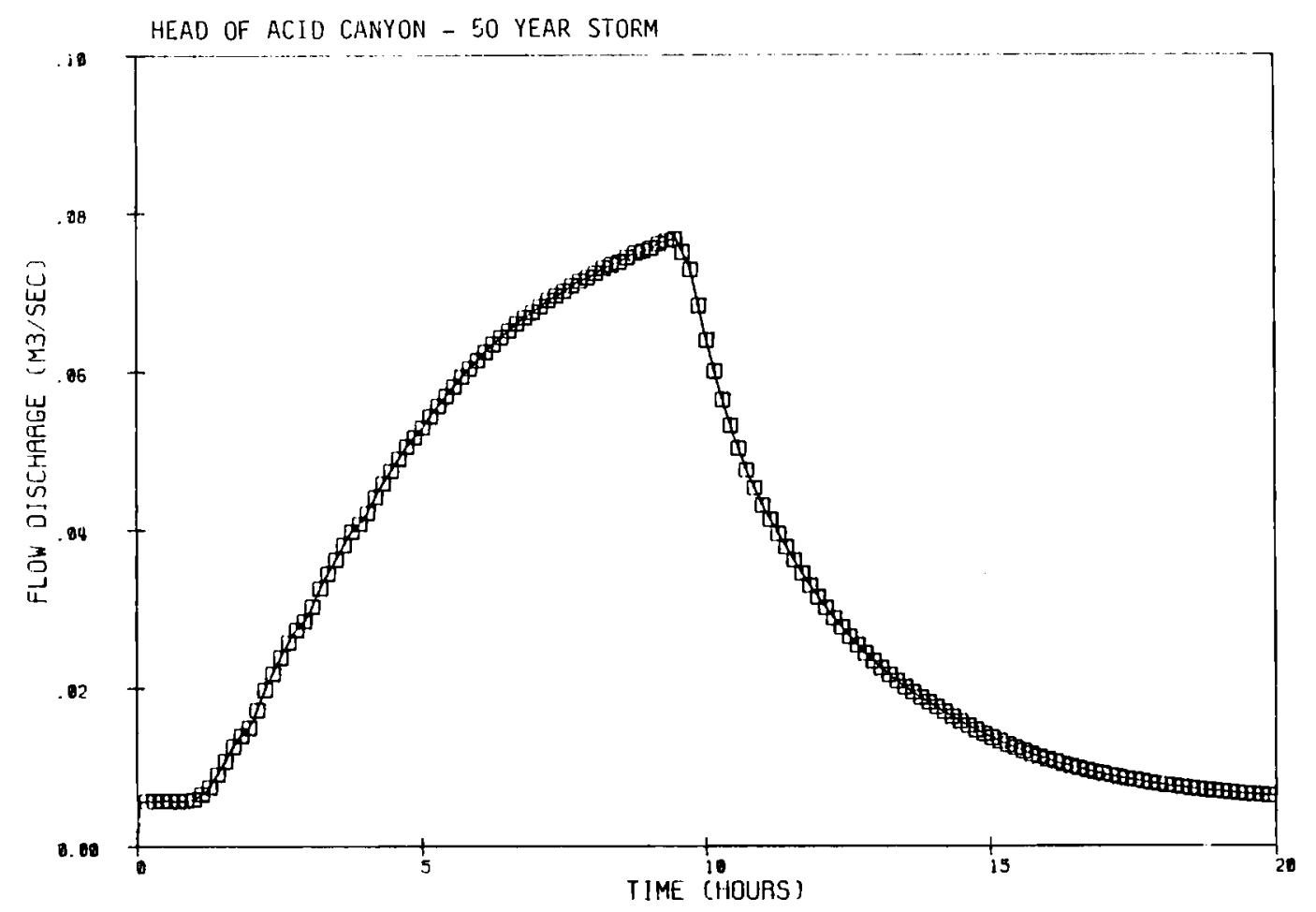

FIGURE 4.28. Discharges Distributed in Time at the Head of Acid Canyon for the 50-yr Flood Event

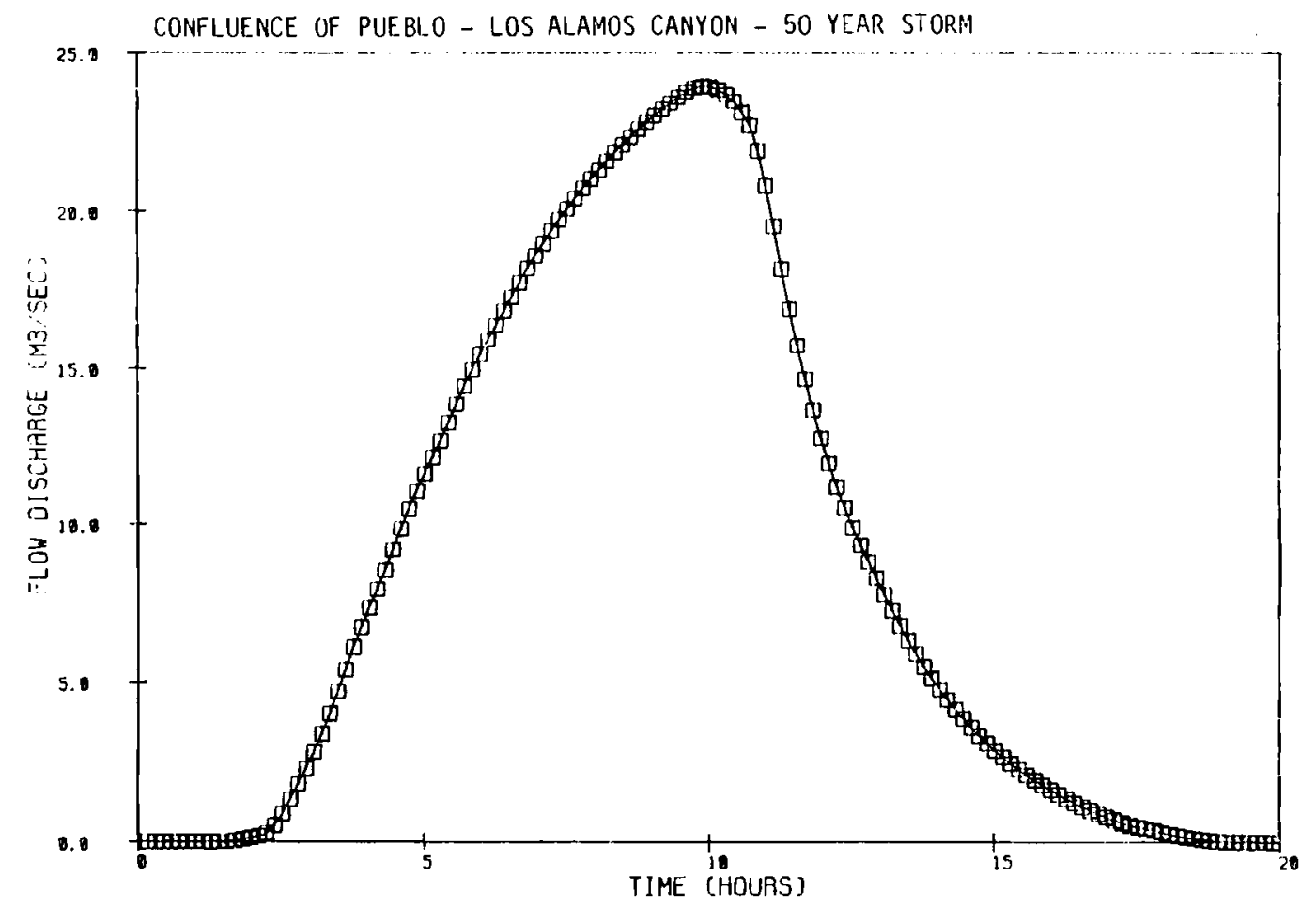

FIGURE 4.29. Discharges Distributed in Time at the Confluence of Pueblo-Los Alamos Canyon for the 50-yr Flood Event 


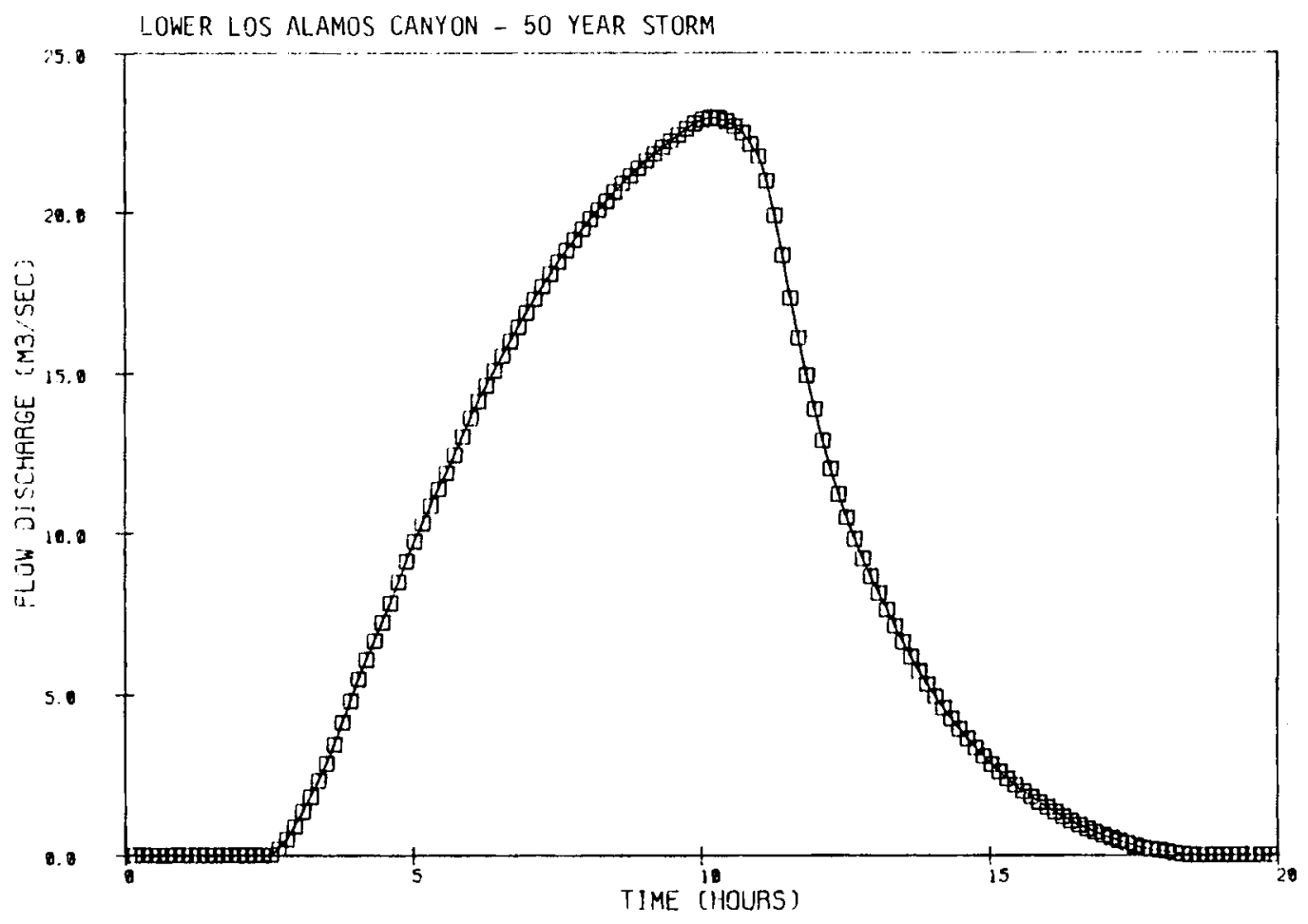

FIGURE 4.30. Discharges Distributed in Time at Lower Los Alamos Canyon for the 50-yr Flood Event

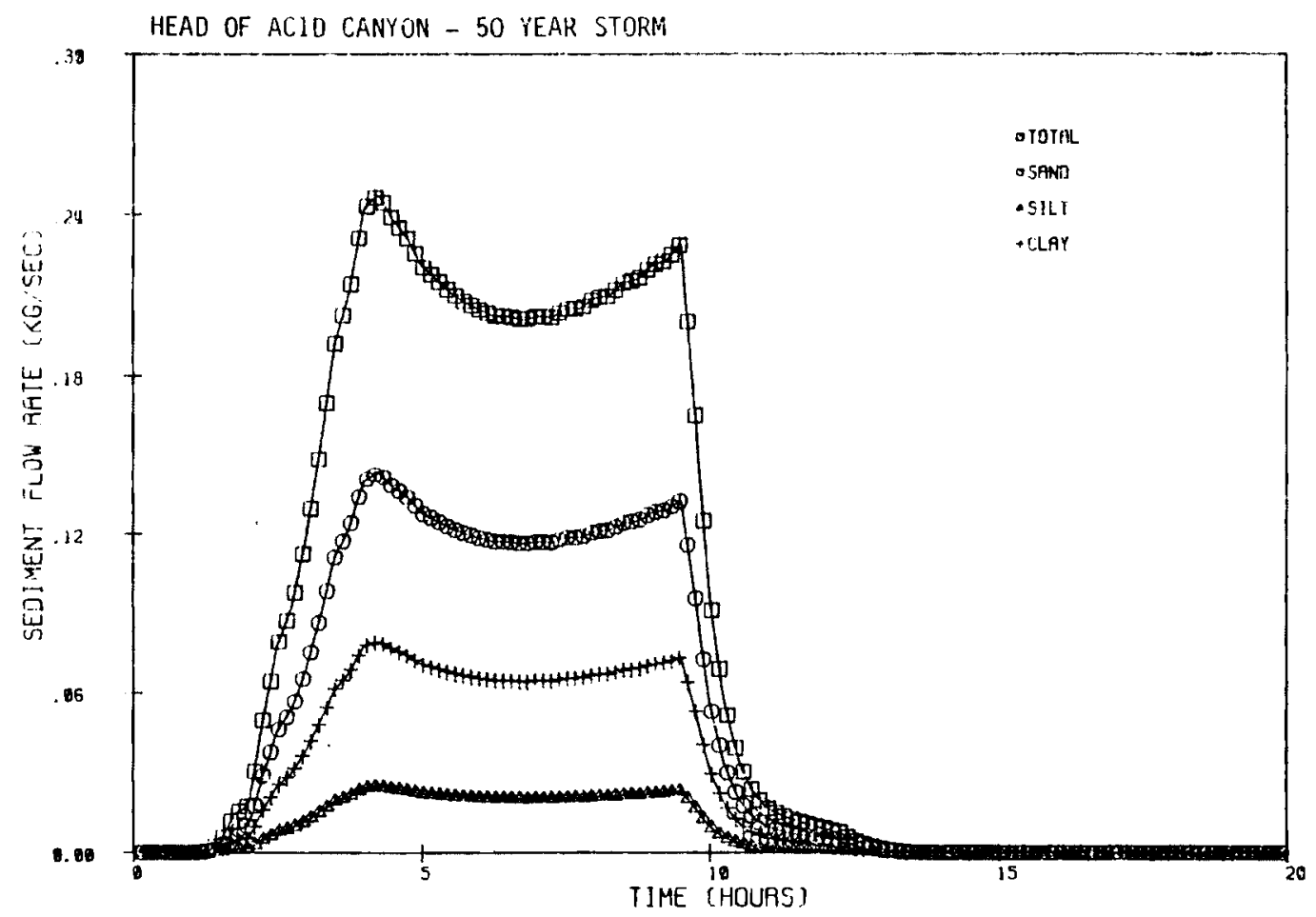

FIGURE 4.31. Sediment Flow Rates Distributed in Time at the Head of Acid Canyon for the 50-yr Flood Event 


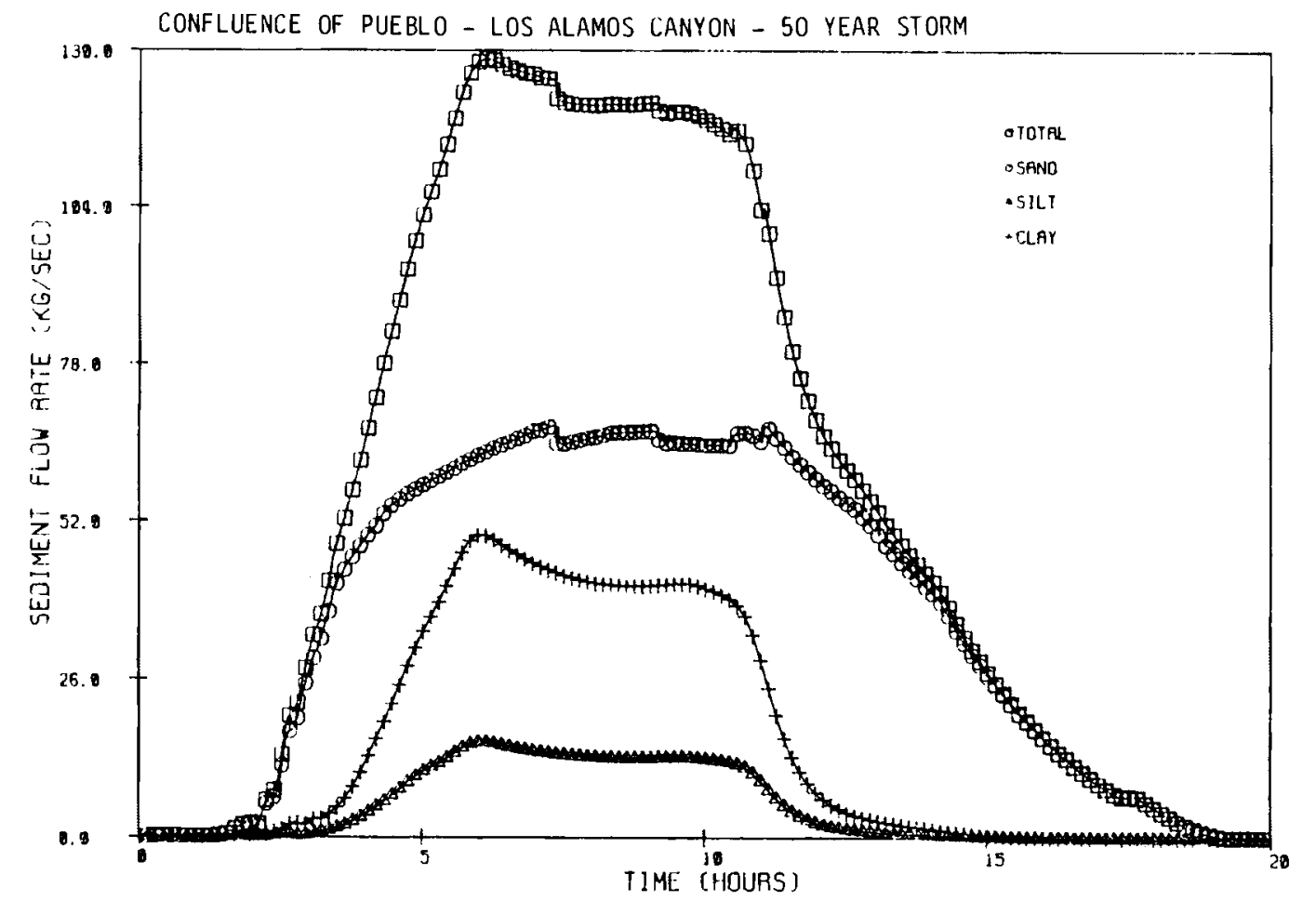

FIGURE 4.32. Sediment Flow Rates Distributed in Time at the Confluence of Pueblo-Los Alamos Canyon for the 50-yr Flood Event LOWER LOS ALAMIOS CANYON - 50 YEAR STORM

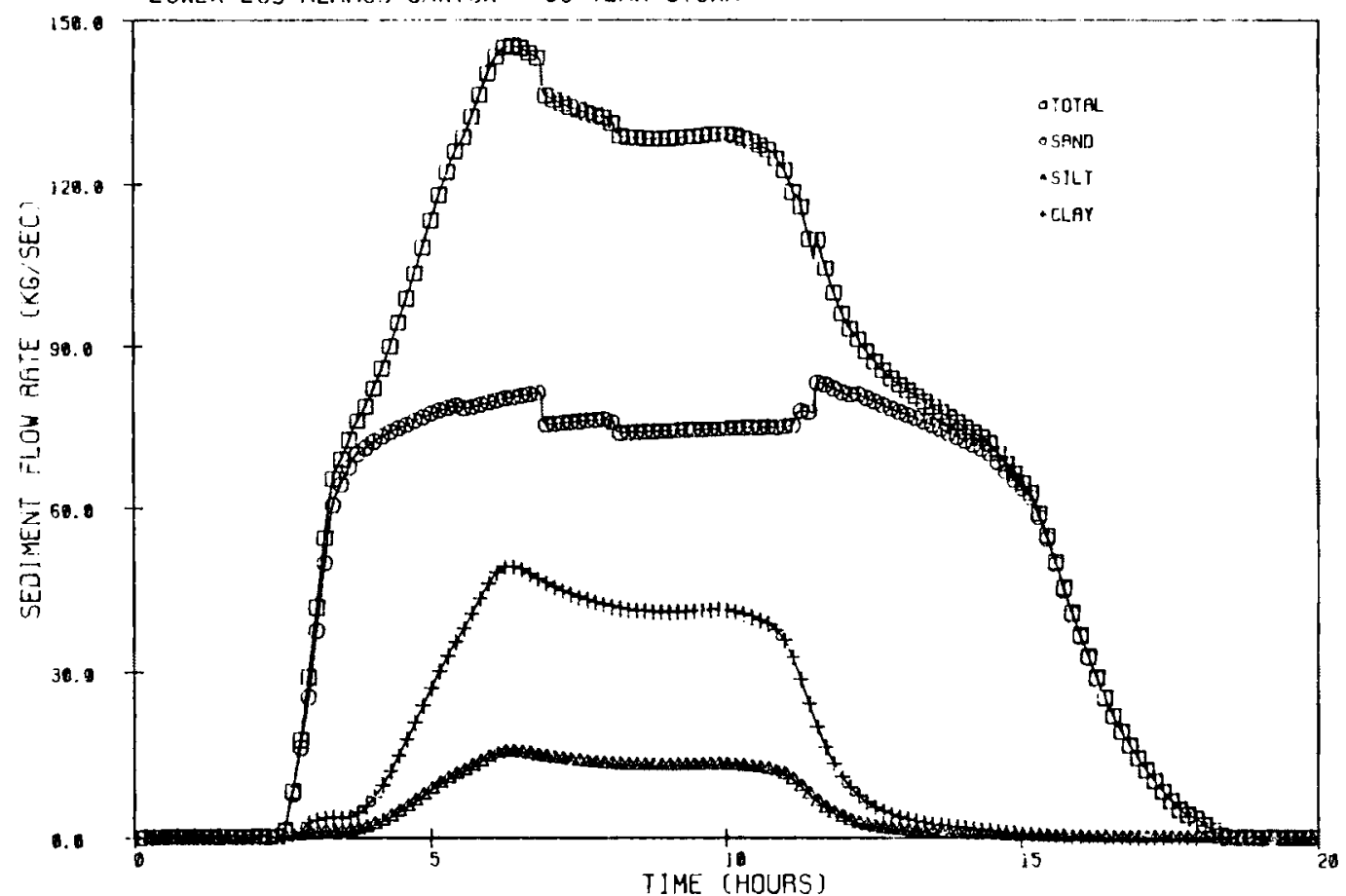

FIGURE 4.33. Sediment Flow Rates Distributed in Time at Lower Los Alamos Canyon for the 50-yr Flood Event 
transport capacity of the flow for this area is attained. Channel segments 34 through 38, therefore, carry a larger sediment load in suspension then in lower Pueblo Canyon while depositing sediment.

The suspended sediment distribution among sand, silt, and clay does not appear to change appreciably from node 1 to node 30 (see Figures 4.31 and 4.32). This is not the case for nodes lying in between. Between nodes 1 and 30 sand is being deposited as well as resuspended, while the cohesive sediments are being suspended only and they are being carried through the system. Because of the fact that sand is being deposited at certain locations (e.g., channel segments 5 through 16), the distribution of sand, silt, and clay favors that of the conesive sediments. By the time the sediment flood wave reaches node 30 , a significant amount of sand was entrained and entered as lateral inflow.

Figure 4.34 presents the simulated net weight of sediment deposited/ resuspended to/from the bed for the 50-yr flood event. Based on Figure 4.34, Acid-Pueblo-lower Los Alamos Canyon could be schematically divided into five distinct regions: Region I (Acid and upper Pueblo Canyons) consisting of channel segments 1 through 4, Region II (middle Pueblo Canyon) consisting of channel segments 5 through 16, Region III (10wer Pueblo Canyon) consisting of channel segments 17 through 29, Region IV (lower Los Alamos Canyon) consisting of channel segments 30 through 33, and Region $V$ (lower Los Alamos Canyon) consisting of channel segments 34 through 38. The net erosion in Region $I$ is due in large part to the significant influx of water into the channel from upper Pueblo Canyon, thereby increasing the sediment entrainment. As the flow proceeds to Region II, the sediment transport capacity decreases resulting in some deposition of the suspended sediment. Based on topographic maps, generally one might expect erosion in this region. Obtaining accurate cross sections from the topographic maps of this area (20-foot contour intervals) were impossible, especially when one considers that the depth of flow was only a couple of feet. Only one cross-sectional shape was provided for in this region. It was located just below the confluence of Acid and Pueblo Canyons. Due to a lack of information for the remaining cross sections in Region II, this cross section was employed. Unfortunately, it appears that this cross section does not exibit enough of the characteristics of the Region. 


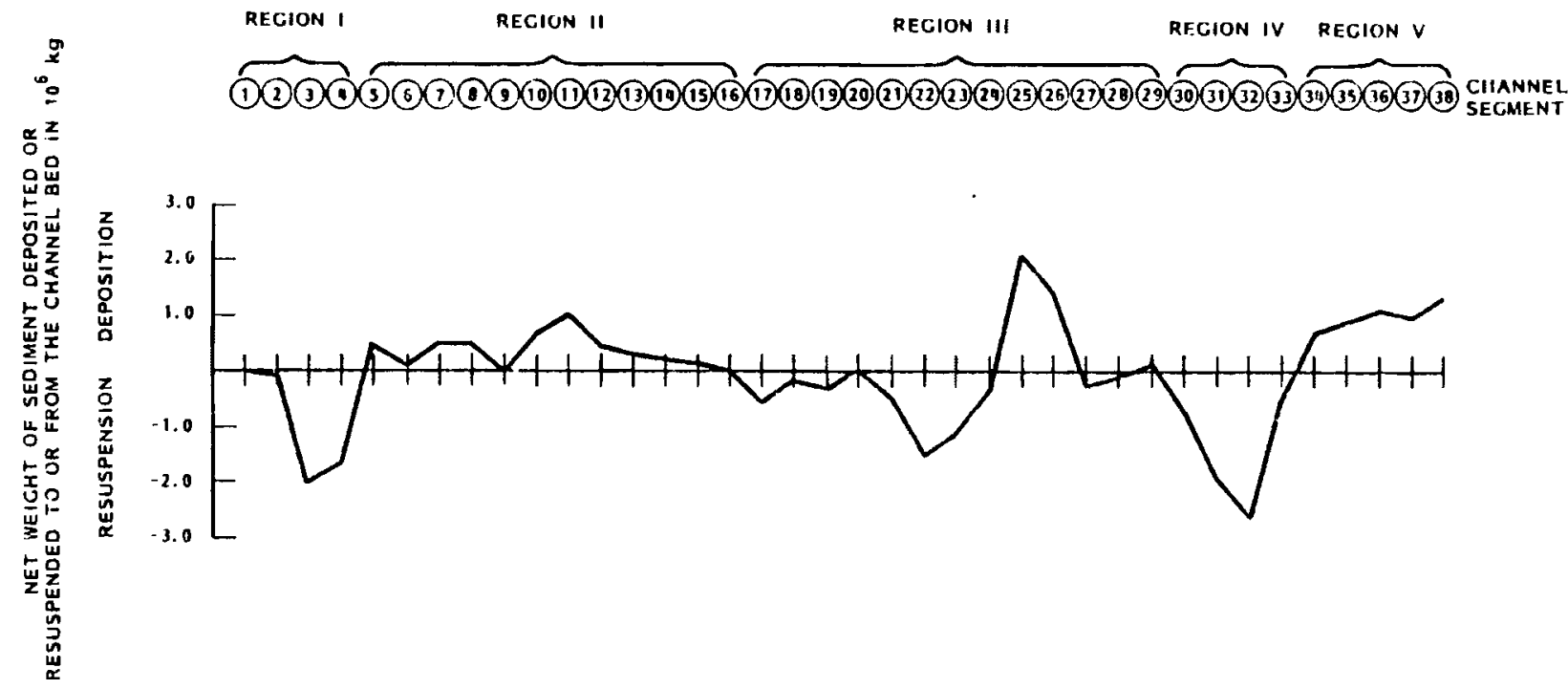

FIGURE 4.34. Simulated Net Weight of Sediment Deposited/Resuspended to/from the Channel Bed for the 50-yr Flood Event

Very little cross-sectional information was available for Region III. The cross-sectional shapes for this region were obtained from topographic maps with 5-foot contour intervals. The cross sections obtained from these maps were less than adequate and for very high flows the effect of the wide area becomes important, but for smaller flows (such as the range encountered here) a channelized situation is simulated, thereby increasing the sediment transport capacity (and erosion). With 5-foot contour intervals, adequate description of the cross section becomes impossible. The cross sections obtained from the topographic map were used, though, because this situation maximizes the possibility of entraining contaminated sediment into the flow to be transported downstream to lower Los Alamos Canyon and because another adequate description of the area did not exist.

As mentioned in previous paragraphs, Region IV is characterized by narrow cross sections and high gradients. These characteristics tend to increase the transport capacity of the flow, entraining significant quantities of sediment. The wider cross-sectional shapes and smaller gradients which characterize 
Region $V$ result in a reduced sediment transport capacity of the flow (relative to channel sections 30 through 33) promoting deposition in this area. For example, Region IV has an average slope of $6.6 \%$, while Region $V$ has an average slope of $3.4 \%$. Also, very little silt or clay was deposited in the bed.

It should be pointed out that the mechanisms governing the deposition and resuspension of sediment in stream is a function of several factors. Some of these include bed slope, flow velocity, shear stress, cross-sectional shape, bed roughness, sediment characteristics, fluid characteristics, watershed characteristics, etc. This represents highly complex phenomena. The alluvial sediment resuspension and deposition were computed using Toffaleti's algorithim for predicting sediment migration. In all cases, sediment deposition or resuspension was computed by comparing the sediment transport capacity to that actually being transported in stream. If the former is larger, bed erosion occurs; while if the latter is larger, deposition of sediment occurs. For example, Region II represents an area of deposition. A closer inspection of the region will indicate why. In this area, the slope is decreasing; the velocity is decreasing because the cross-sectional area is increasing more than the discharge is increasing; and the shear stress is decreasing. The net result is that sediment is depositing in this area. The degree of erosion or deposition is a function of the characteristics describing the phenomena. If it appears that too much or too little sediment movement is occurring in the bed, then the input data provided should be rechecked as the results are only as good as the data provided. The results are also only as good as the assumptions the phenomena are based on. Several limitations in the sediment algorithms do exist: The bed slopes are not updated for every time increment. As the slope decreases, one would expect the transport capacity to decrease also, and the procedure employed for computing armoring may have shortcomings. Since only one alluvial size is employed, the degree of armoring of the bed may be underestimated. By including larger alluvial-sized particles, the amount of sediment entrainment from the bed may be less than that estimated in the simulation.

Figures 4.35 and 4.36 present the ${ }^{239} \mathrm{Pu}$ flux in the particulate and dissolved phases at the confluence of Pueblo-Los Alamos Canyon and lower Los Alamos Canyon, respectively, for the 50-yr flood event. A plot representing ${ }^{239} \mathrm{Pu}$ flux at the head of Acid Canyon was not presented because no ${ }^{239} \mathrm{Pu}$ 
entered the first node as all of the contamination was contained in the bed. The peak ${ }^{239} \mathrm{Pu}$ flux at node two, though, was $1.4 \times 10^{4} \mathrm{pCi} / \mathrm{sec}$. This amount represents approximately $20.8 \%$ of the peak at the confluence of Pueblo-Los Alamos Canyon. The inventory of ${ }^{239} \mathrm{Pu}$ passing the nodes between 1 and 30 follow the pattern established by the movement of sediment to and from the bed as depicted in Figure 4.35. The amount of ${ }^{239} \mathrm{Pu}$ migrating downstream increases in Region I and this coincides with resuspension of sediment from the bed. As deposition of sediment occurs in Region II, there is a concurrent drop in the amount of $239 \mathrm{Pu}$ migrating downstream. In general, the areas of bed erosion reflect an increase in the migration of ${ }^{239} \mathrm{Pu}$, while areas experiencing sediment deposition reflect a decrease in the migration of $230 \mathrm{Pu}$. Of the total inventory passing node 33 , approximately $56 \%$ is carried through towards the Rio Grande past node 39. At this point (node 39), the uncontaminated flow from Bayo Canyon would combine with the flow from Los Alamos Canyon increasing the flow towards the Rio Grande. As Figures 4.35 and 4.36 reveal, most of the contamination is migrating in the particulate phase with little in the dissolved phase. This is expected, since the ${ }^{239} \mathrm{Pu}$ was already adsorbed onto the sediment before the simulation process started. As stated before, contaminants tend to desorb from sediment at a much slower rate than when they adsorb to the sediments initially. Approximately $0.03 \%$ of the ${ }^{239} \mathrm{Pu}$ is migrating in a dissolved form, while approximately $99.97 \%$ is migrating in a particulate form. As Figures 4.35 and 4.36 reveal, there is a $5 \%$ drop in the peak ${ }^{239} \mathrm{Pu}$ discharge from the confluence of Pueblo-Los Alamos Canyon to that of lower Los Alamos Canyon (node 39), as well as a 5\% drop in the net inventory of plutonium passing nodes 30 and 39. These circumstances can be explained as follows: As mentioned earlier, there is a net amount of erosion of sediment from channel segments 30 through 33 (see figure 4.34) where the particulate concentration is less than that which is in stream. [It should be noted that a major part of this sediment is uncontaminated as well.] The effect of combining this resuspended sediment with the contaminated sediment already suspended in stream reduces the average ${ }^{239} \mathrm{Pu}$ concentration ( ${ }^{239} \mathrm{Pu}$ adsorbed to sediment). This, combined with the fact that only $53.5 \%$ of the amount of sediment passing node 33 passes node 39 , explains why there is a drop in the peak ${ }^{239} \mathrm{Pu}$ flux and ${ }^{239} \mathrm{Pu}$ inventory of $5 \%$ from node 30 to node 39. 


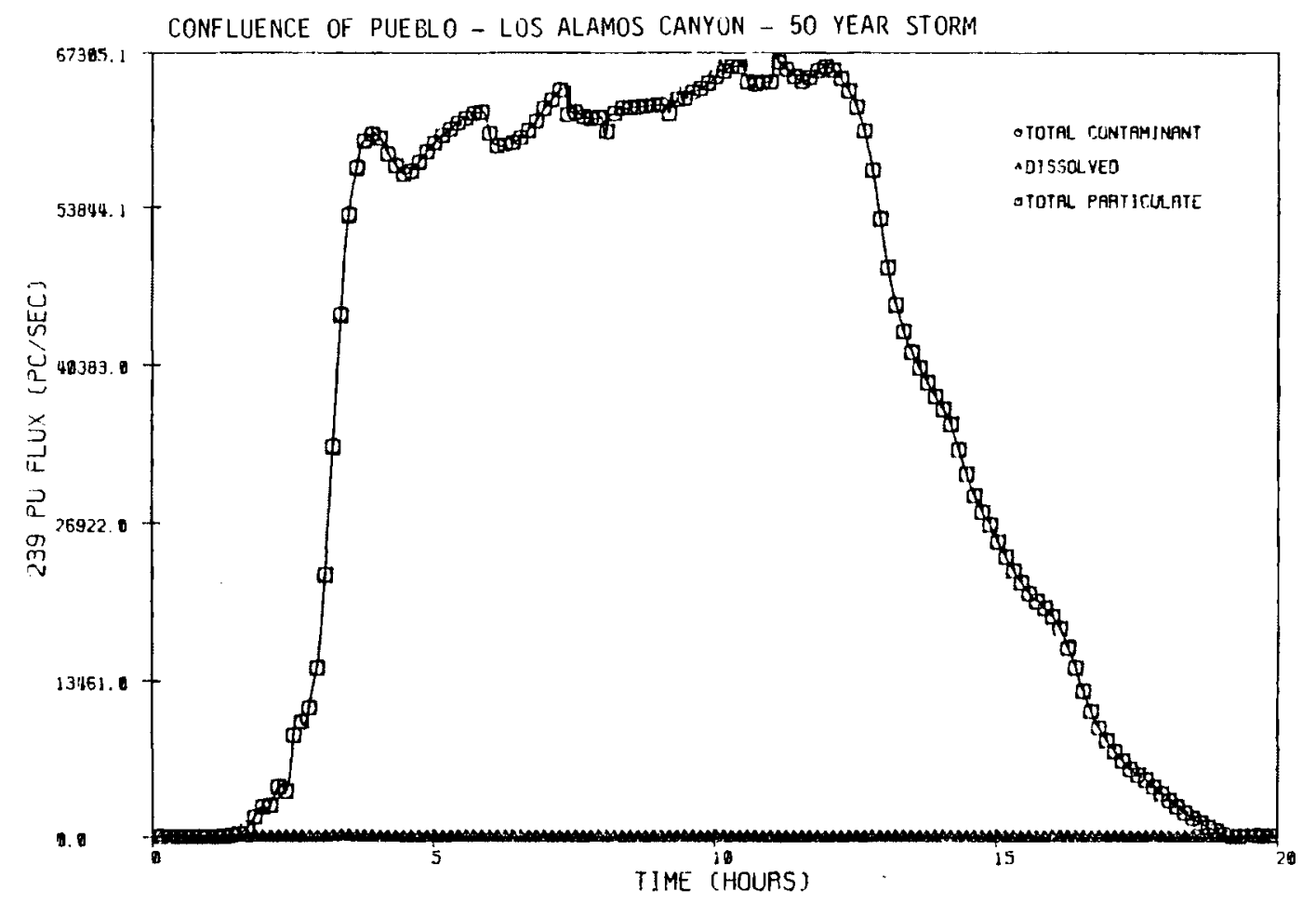

FIGURE 4.35. Plutonium-239 Flow Rates Distributed in Time at the Confluence of Pueblo-Los Alamos Canyon for the 50-yr Flood Event

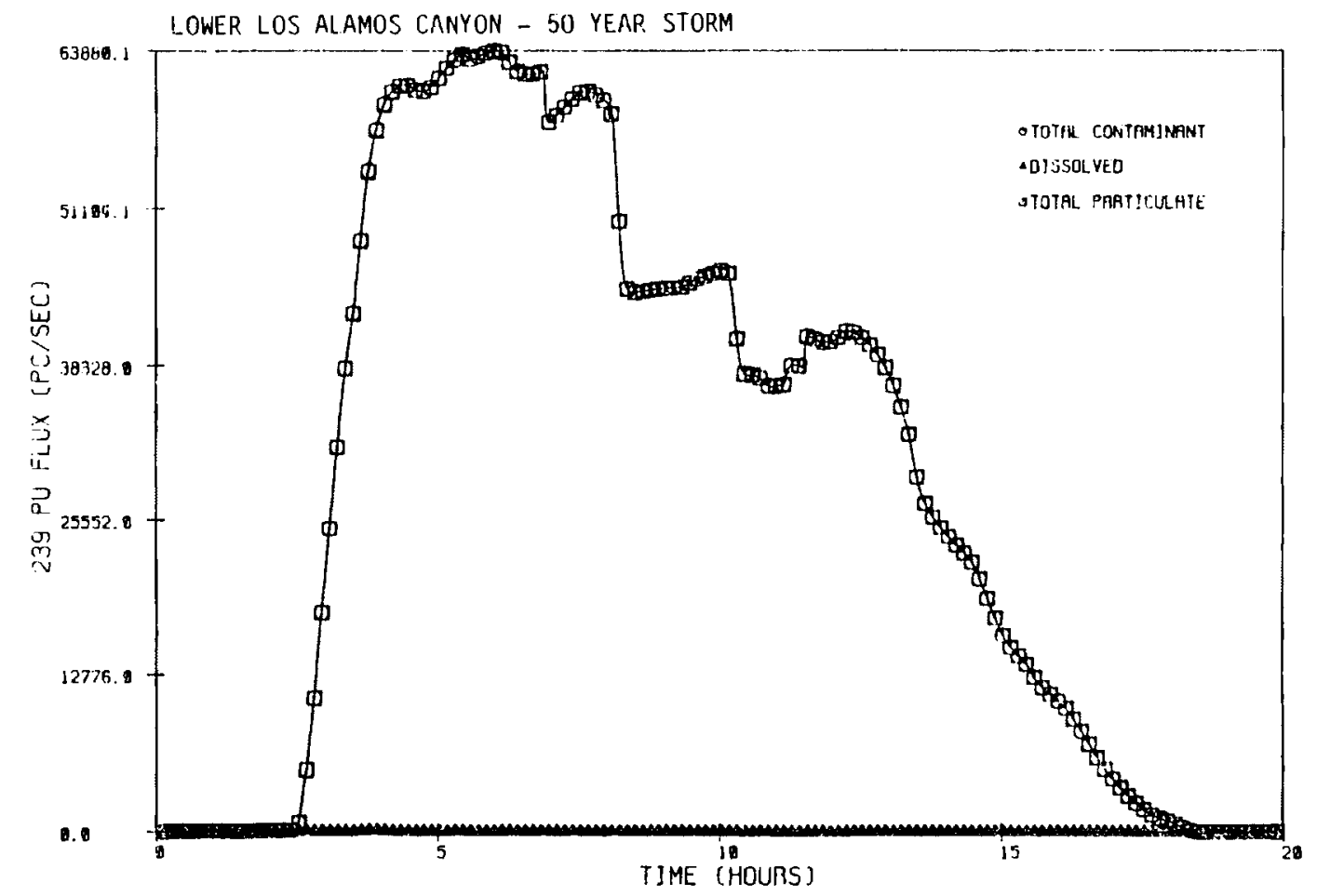

FIGURE 4.36. Plutonium-23y Flow Rates Distributed in Time at Lower Los Alamos Canyon for the 50-yr Flood Event

4.97 
Figures 4.37 and 4.38 present the particulate phase of the ${ }^{239} \mathrm{Pu}$ flux distributed by sediment size at the confluence of Pueblo-Los Alamos Canyon and lower Los Alamos Canyon, respectively. The particulate radionuclide distribution for sand, silt, and clay as presented by Figures 4.37 and 4.38 is approximately 93, 3, and 4 and 91,4 , and 5, respectively. The decrease in the percent ${ }^{239} \mathrm{Pu}$ associated with sand is due to deposition of sand at channel segments 34 through 38 . Since a significant portion of the cohesive sediments originated from uncontaminated overland segments and since the majority of the inventory of ${ }^{239} \mathrm{Pu}$ is adsorbed to sand, it was expected that sand would be carrying the majority of ${ }^{239} \mathrm{Pu}$.

The corresponding particulate phase of the ${ }^{239} \mathrm{Pu}$ concentration in $\mathrm{pCi} / \mathrm{kg}$ for each sediment size at the confluence of Pueblo-Los Alamos Canyon and lower Los Alamos Canyon is presented in Figures 4.39 and 4.40 , respectively, for the $50-y r$ flood event. The corresponding particulate phase of the ${ }^{239} \mathrm{Pu}$ concentration for sand, silt, and clay during the majority of the runoff event at node 30 was approximately $900 \mathrm{pCi} / \mathrm{kg}, 75 \mathrm{pCi} / \mathrm{kg}$, and $30 \mathrm{pCi} / \mathrm{kg}$, respectively. At first glance, these values would appear incorrect as clay and silt usually have higher particulate ${ }^{239} \mathrm{Pu}$ concentrations associted with them than sand. Closer inspection indicates that these concentration levels are correct. Most of the suspended particulate ${ }^{239} \mathrm{Pu}$ concentrations associated with sand are at levels found in the bed (see Table 4.28). Over 98\% of the sand in suspension originated from the channel bed, while only $2 \%$ originated from overland areas devoid of ${ }^{239} \mathrm{Pu}$ contamination. On the other hand, $83 \%$ of the clay in suspension originated from uncontaminated overland segments. The suspended particulate ${ }^{239} \mathrm{Pu}$ concentrations associated with clay are relatively low because the model uniformly distributes the ${ }^{239} \mathrm{Pu}$ concentration instantaneously among all clay particles. Since most of the clay particles originate from uncontaminated overland segments, the concentration was expected to drop. The rate at which the ${ }^{239} \mathrm{Pu}$ is adsorbed/desorbed $\left(\mathrm{k}_{j}\right)$ to the equilibrium $\mathrm{kd}_{j}$ value was assumed small (based on calibration) so significant changes in particulate concentrations are not expected between sediment sizes. It should be noted that most other models assume an instantaneous sorption phenomenon to the equilibrium $\mathrm{Kd}_{\mathrm{j}}$ value. Given the short duration of the storm, this approach would appear unrealistic. 


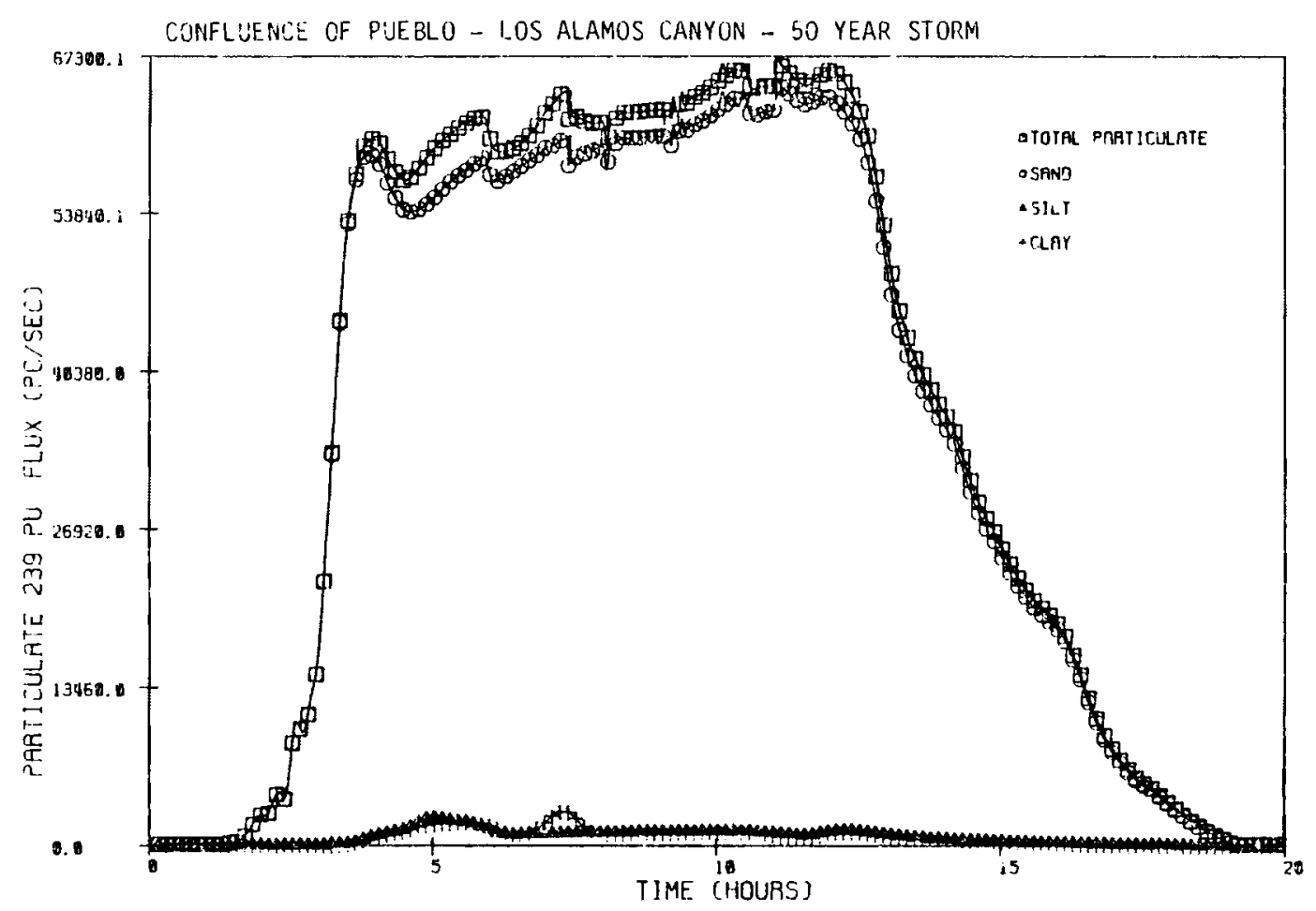

FIGURE 4.37. Particulate ${ }^{239} \mathrm{Pu}$ Flow Rates Distributed in Time at the Confluence of Pueblo-Los Alamos Canyon for the 50-yr Flood Event

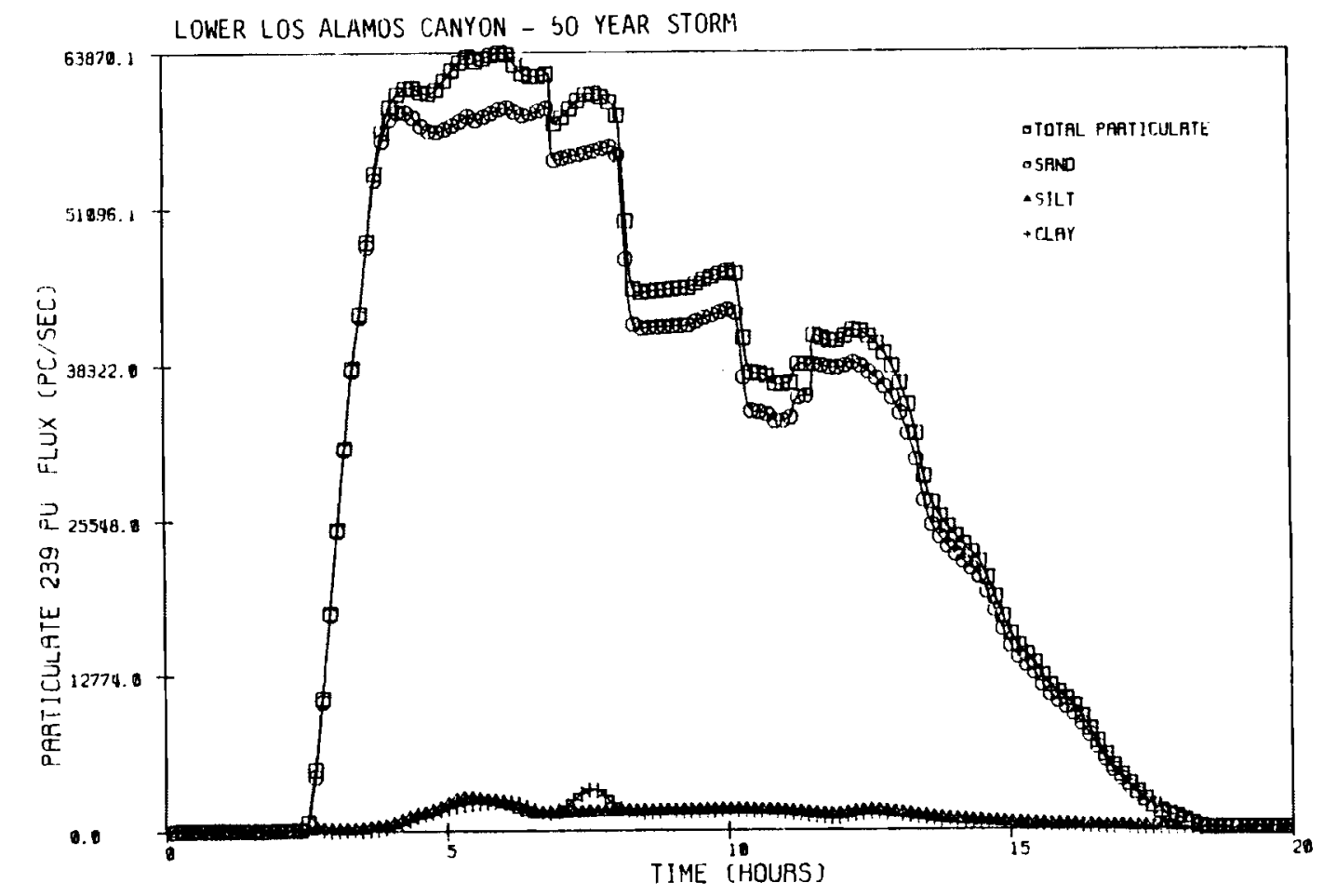

FIGURE 4.38. Particulate ${ }^{239} \mathrm{Pu}$ Flow Rates Distributed in Time at Lower Los Alamos Canyon for the 50-yr Flood Event 
The particulate ${ }^{239} \mathrm{Pu}$ concentrations generally associated with sand, silt, and clay at node 39 during the majority of the runoff event was approximately $750 \mathrm{pCi} / \mathrm{kg}, 140 \mathrm{pCi} / \mathrm{kg}$, and $50 \mathrm{pCi} / \mathrm{kg}$. The particulate ${ }^{239} \mathrm{Pu}$ concentrations associated with the alluvial material have decreased by approximately $17 \%$ from node 30 to node 39 , while those associted with the cohesive sediments have increased by approximately $77 \%$. The alluvial 239 pu particulate concentrations have decreased because the contaminated sand entrained into the flow in lower Los Alamos Canyon has a lower ${ }^{239} \mathrm{Pu}$ particulate concentration associated with it than that in the flow with a major portion of this sediment being uncontaminated. On the other hand, the contaminated cohesive sediments entrained into the flow in lower Los $\mathrm{Al}$ amos Canyon have higher ${ }^{239} \mathrm{Pu}$ particulate concentrations associated with them than that in the flow. Also, it should be noted that there is no lateral inflow of sediment from overland segments in lower Los Alamos Canyon.

Table 4.29 presents the ${ }^{239} \mathrm{Pu}$ concentrations per contaminated bed layer in Acid-Pueblo-lower Los Alamos Canyon for the 50-yr flood event. Only the layers which contain ${ }^{239} \mathrm{Pu}$ or which were altered due to bed aggradation or degradation are presented in Table 4.29 as all other layers are unaffected and remain the same as their initial conditions. Also presented is the sediment distribution by size fraction (i.e., sand, silt, and clay) for each of the contaminated layers in each channel section. Plutonium-239 concentrations in channel sections experiencing net erosion are very similar to the initial conditions for that section. In channel sections experiencing deposition, only sand is depositing onto the bed, while silts and clays are being carried through the system. Lower Pueblo Canyon did not represent a region where an excessive inventory of ${ }^{239} \mathrm{Pu}$ was deposited as one would expect. The full effect of the wide cross sections characteristic of this region were not fully realized in the modeling scenario as the cross-sectional shapes were estimated from topographic maps with $5 \mathrm{ft}$ contour intervals. As it turned out, the depth of flow was below $5 \mathrm{ft}$. The net amount of ${ }^{239} \mathrm{Pu}$ resuspended from channel sections experiencing degradation for the 50-year flood event represented approxinately $1 \%$ to $2 \%$ of the initial $239 \mathrm{Pu}$ inventory comprising the channel bed. Of this amount, $27 \%$ of the ${ }^{239} \mathrm{Pu}$ resuspended from the entire bed originated from lower Pueblo Canyon. 


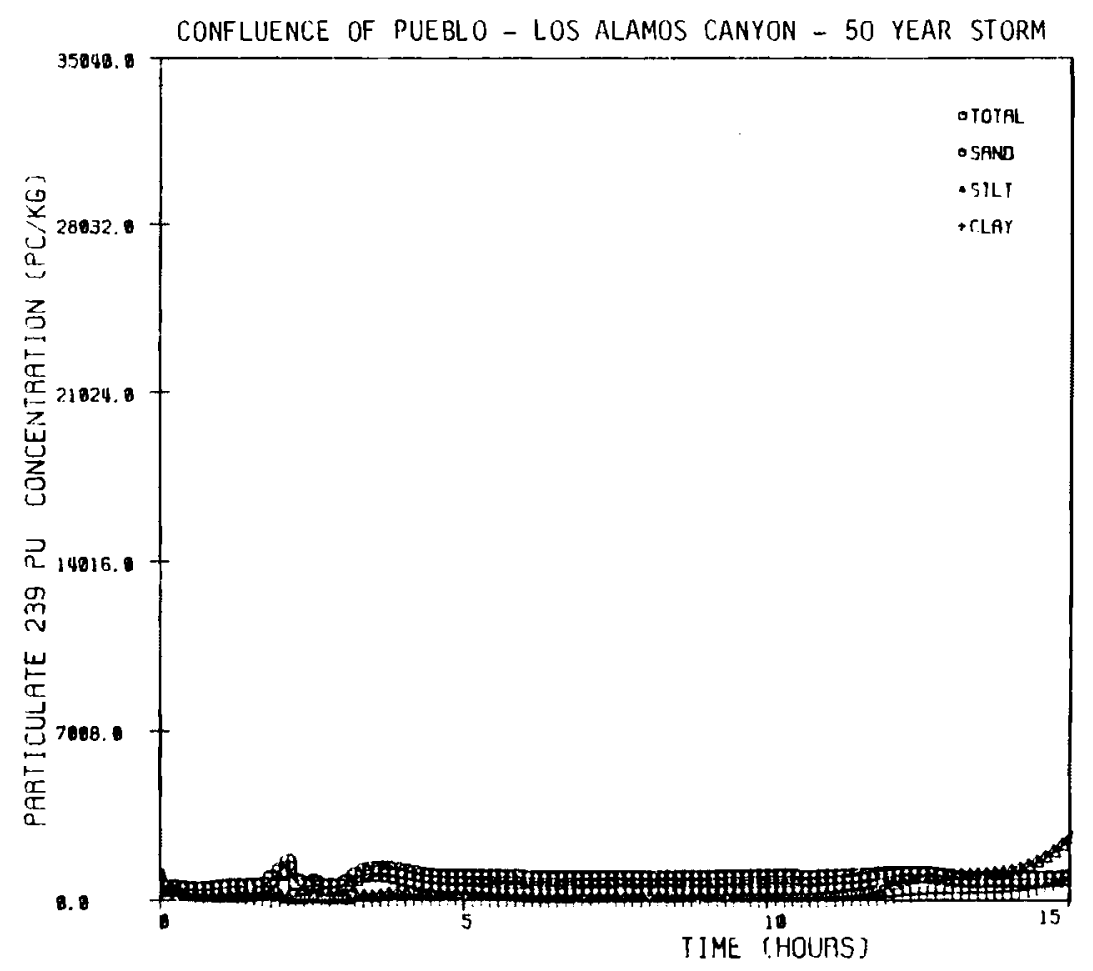

FIGURE 4.39. Particulate 239pu Concentrations in $\mathrm{pCi} / \mathrm{kg}$ Distributed in Time at the Confluence of Pueblo-Los Alamos Carlyon for the 50-yr Flood Event

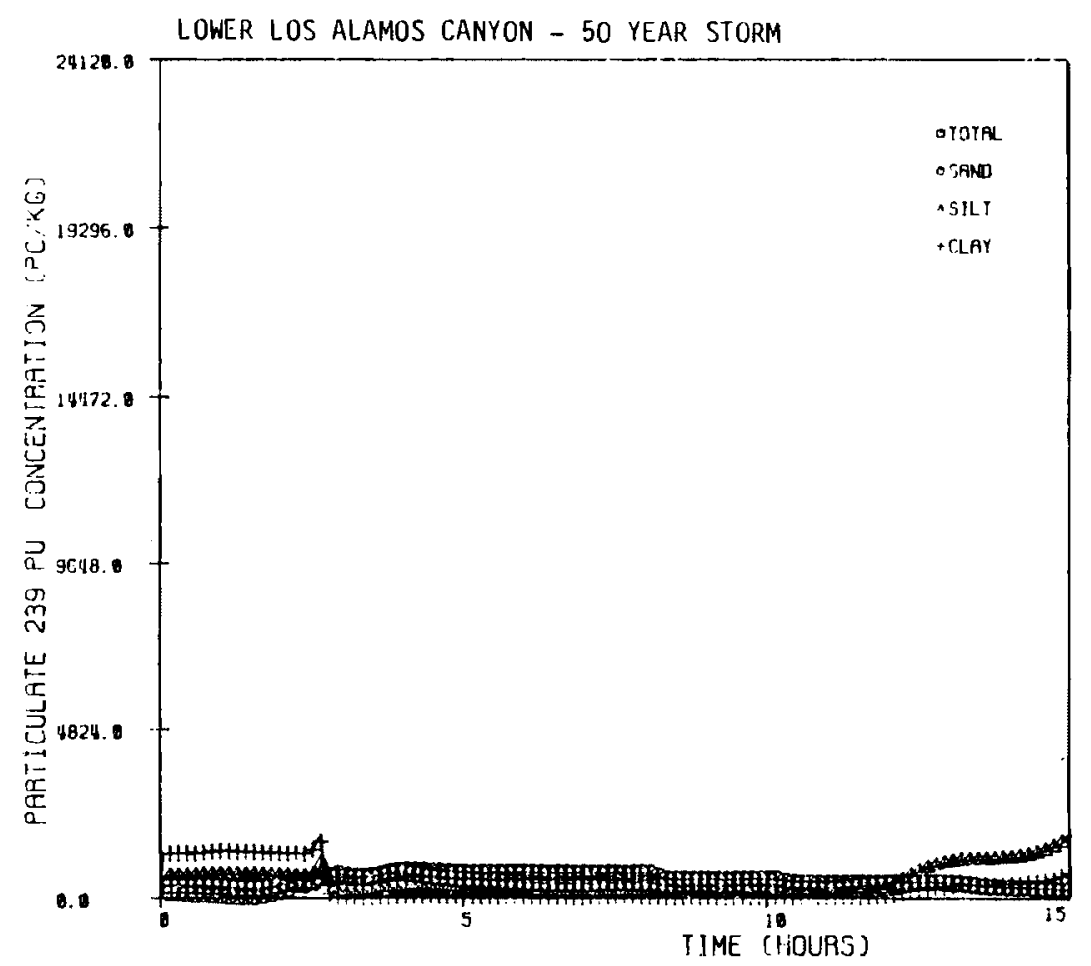

FIGURE 4.40. Particulate 239pu Concentrations in $\mathrm{pCi} / \mathrm{kg}$ Distributed in Time at Lower Los Alamos Canyon for the 50-yr Flood Event 
TABLE 4.29. Plutonium-239 Concentrations per Contaminated Bed Layer in AcidPueblo-Lower Los Alamos Canyon for the 50-yr Flood Event

\begin{tabular}{|c|c|c|c|c|c|c|c|}
\hline \multirow[b]{2}{*}{$\begin{array}{l}\text { Channel } \\
\text { Section }\end{array}$} & \multirow{2}{*}{$\begin{array}{c}\text { Contaminated } \\
\text { Layer } \\
\text { Number } \\
\end{array}$} & \multirow{2}{*}{$\begin{array}{l}\% \text { Sand } \\
\text { in Bed } \\
\text { Layer } \\
\end{array}$} & \multirow{2}{*}{$\begin{array}{l}\% \text { Silt } \\
\text { in Bed } \\
\text { Layer } \\
\end{array}$} & \multirow{2}{*}{$\begin{array}{l}\% \text { Clay } \\
\text { in Bed } \\
\text { Layer } \\
\end{array}$} & \multicolumn{3}{|c|}{$\begin{array}{l}\text { 239 Particulate } \\
\text { Pu Concentrations } \\
\text { Adsorbed by Sediment }\end{array}$} \\
\hline & & & & & $\begin{array}{c}\text { Sand } \\
(\mathrm{pCi} / \mathrm{kg})\end{array}$ & $\begin{array}{c}\text { Silt } \\
(\mathrm{pCi} / \mathrm{kg}) \\
\end{array}$ & $\begin{array}{c}\text { Clay } \\
(p \mathrm{ci} / \mathrm{kg}) \\
\end{array}$ \\
\hline \multirow[t]{2}{*}{1} & 8 & 99.5 & 0.1 & 0.4 & $9.26 \times 10^{5}$ & $4.63 \times 10^{6}$ & $9.26 \times 10^{6}$ \\
\hline & 9 & 100.0 & 0.0 & 0.0 & $5.22 \times 10^{3}$ & 0.0 & 0.0 \\
\hline 2 & 8 & 96.8 & 0.8 & 2.4 & $5.20 \times 10^{3}$ & $2.62 \times 10^{4}$ & $5.24 \times 10^{4}$ \\
\hline 3 & 7 & 92.3 & 1.8 & 5.9 & $6.59 \times 10^{1}$ & $3.95 \times 10^{3}$ & $8.32 \times 10^{3}$ \\
\hline 4 & 7 & 95.7 & 1.0 & 3.3 & $1.05 \times 10^{1}$ & $1.61 \times 10^{4}$ & $3.34 \times 10^{4}$ \\
\hline \multirow[t]{2}{*}{5} & 8 & 98.5 & 0.4 & 1.1 & $6.55 \times 10^{3}$ & $3.36 \times 10^{4}$ & $6.72 \times 10^{4}$ \\
\hline & 9 & 100.0 & 0.0 & 0.0 & $2.41 \times 10^{3}$ & 0.0 & 0.0 \\
\hline \multirow[t]{2}{*}{6} & 8 & 97.0 & 0.7 & 2.3 & $6.08 \times 10^{3}$ & $3.04 \times 10^{4}$ & $6.08 \times 10^{4}$ \\
\hline & 9 & 100.0 & 0.0 & 0.0 & $2.09 \times 10^{3}$ & 0.0 & 0.0 \\
\hline \multirow[t]{2}{*}{7} & 8 & 97.0 & 0.8 & 2.2 & $6.08 \times 10^{3}$ & $3.04 \times 10^{4}$ & $6.08 \times 10^{4}$ \\
\hline & 9 & 100.0 & 0.0 & 0.0 & $2.24 \times 10^{3}$ & 0.0 & 0.0 \\
\hline \multirow[t]{2}{*}{8} & 8 & 97.0 & 0.8 & 2.2 & $1.58 \times 10^{2}$ & $7.91 \times 10^{2}$ & $1.58 \times 10^{3}$ \\
\hline & 9 & 100.0 & 0.0 & 0.0 & $2.30 \times 10^{3}$ & 0.0 & 0.0 \\
\hline \multirow[t]{2}{*}{9} & 8 & 97.0 & 0.7 & 2.3 & $1.75 \times 10^{2}$ & $7.91 \times 10^{2}$ & $1.58 \times 10^{3}$ \\
\hline & 9 & 100.0 & 0.0 & 0.0 & $2.25 \times 10^{3}$ & 0.0 & 0.0 \\
\hline \multirow[t]{2}{*}{10} & 8 & 97.0 & 0.8 & 2.3 & $1.59 \times 10^{2}$ & $7.91 \times 10^{2}$ & $1.58 \times 10^{3}$ \\
\hline & 9 & 100.0 & 0.0 & 0.0 & $2.26 \times 10^{3}$ & 0.0 & 0.0 \\
\hline \multirow[t]{3}{*}{11} & 8 & 97.0 & 0.8 & 2.3 & $1.58 \times 10^{2}$ & $7.91 \times 10^{2}$ & $1.58 \times 10^{3}$ \\
\hline & 9 & 100.0 & 0.0 & 0.0 & $2.47 \times 10^{3}$ & 0.0 & 0.0 \\
\hline & 10 & 100.0 & 0.0 & 0.0 & $1.09 \times 10^{3}$ & 0.0 & 0.0 \\
\hline \multirow[t]{2}{*}{12} & 8 & 97.0 & 0.8 & 2.3 & $1.64 \times 10^{2}$ & $7.91 \times 10^{2}$ & $1.58 \times 10^{3}$ \\
\hline & 9 & 100.0 & 0.0 & 0.0 & $2.21 \times 10^{3}$ & 0.0 & 0.0 \\
\hline \multirow[t]{2}{*}{13} & 8 & 97.0 & 0.8 & 2.3 & $1.67 \times 10^{2}$ & $7.91 \times 10^{2}$ & $1.58 \times 10^{3}$ \\
\hline & 9 & 100.0 & 0.0 & 0.0 & $2.15 \times 10^{3}$ & 0.0 & 0.0 \\
\hline 14 & 8 & 97.0 & 0.8 & 2.3 & $1.59 \times 10^{2}$ & $7.91 \times 10^{2}$ & $1.58 \times 10^{3}$ \\
\hline & 9 & 100.0 & 0.0 & 0.0 & $2.07 \times 10^{3}$ & 0.0 & 0.0 \\
\hline \multirow[t]{2}{*}{15} & 8 & 97.0 & 0.8 & 2.3 & $1.58 \times 10^{2}$ & $7.91 \times 10^{2}$ & $1.58 \times 10^{3}$ \\
\hline & 9 & 100.0 & 0.0 & 0.0 & $1.99 \times 10^{3}$ & 0.0 & 0.0 \\
\hline \multirow[t]{2}{*}{16} & 8 & 97.0 & 0.7 & 2.3 & $1.77 \times 10^{2}$ & $7.91 \times 10^{2}$ & $1.58 \times 10^{3}$ \\
\hline & 9 & 100.0 & 0.0 & 0.0 & $1.67 \times 10^{3}$ & 0.0 & 0.0 \\
\hline \multirow{2}{*}{$\begin{array}{l}17 \\
18\end{array}$} & 8 & 96.0 & 1.0 & 3.0 & $1.58 \times 10^{2}$ & $7.91 \times 10^{2}$ & $1.58 \times 10^{3}$ \\
\hline & 8 & 96.7 & 0.8 & 2.5 & $2.43 \times 10^{2}$ & $1.18 \times 10^{3}$ & $2.36 \times 10^{3}$ \\
\hline \multirow{2}{*}{$\begin{array}{l}19 \\
20\end{array}$} & 8 & 87.3 & 3.2 & 9.5 & $2.36 \times 10^{2}$ & $1.18 \times 10^{3}$ & $2.36 \times 10^{3}$ \\
\hline & 8 & 88.9 & 2.8 & 8.3 & $1.59 \times 10^{2}$ & $7.85 \times 10^{2}$ & $1.57 \times 10^{3}$ \\
\hline 21 & 8 & 86.8 & 3.3 & 9.9 & $1.57 \times 10^{2}$ & $7.85 \times 10^{2}$ & $1.57 \times 10^{3}$ \\
\hline \multirow{2}{*}{$\begin{array}{l}22 \\
23\end{array}$} & 8 & 83.1 & 4.2 & 12.7 & $1.47 \times 10_{3}^{3}$ & $7.37 \times 10^{3}$ & $1.47 \times 10^{4}$ \\
\hline & 8 & 85.3 & 3.7 & 11.0 & $1.47 \times 10_{3}^{3}$ & $7.37 \times 10_{2}^{3}$ & $1.47 \times 10^{4}$ \\
\hline \multirow{3}{*}{$\begin{array}{l}24 \\
25\end{array}$} & 8 & 87.9 & 3.0 & 9.1 & $1.47 \times 10^{3}$ & $7.37 \times 10^{3}$ & $1.47 \times 10^{4}$ \\
\hline & 8 & 89.0 & 2.8 & 8.2 & $1.47 \times 10^{3}$ & $7.37 \times 10^{3}$ & $1.47 \times 10^{4}$ \\
\hline & 9 & 100.0 & 0.0 & 0.0 & $1.11 \times 10^{3}$ & 0.0 & 0.0 \\
\hline
\end{tabular}


TABLE 4.29. (contd)

\begin{tabular}{|c|c|c|c|c|c|c|c|}
\hline \multirow[b]{2}{*}{$\begin{array}{l}\text { Channel } \\
\text { Section }\end{array}$} & \multirow{2}{*}{$\begin{array}{c}\text { Contaminated } \\
\text { Layer } \\
\text { Number } \\
\end{array}$} & \multirow{2}{*}{$\begin{array}{l}\% \text { Sand } \\
\text { in Bed } \\
\text { Layer }\end{array}$} & \multirow{2}{*}{$\begin{array}{l}\% \text { Silt } \\
\text { in Bed } \\
\text { Layer }\end{array}$} & \multirow{2}{*}{$\begin{array}{l}\% \text { Clay } \\
\text { in Bed } \\
\text { Layer }\end{array}$} & \multicolumn{3}{|c|}{$\begin{array}{l}\text { 239 Particulate } \\
\text { Pu Concentrations } \\
\text { Adsorbed by Sediment } \\
\end{array}$} \\
\hline & & & & & $\begin{array}{c}\text { Sand } \\
(p C i / k g)\end{array}$ & $\begin{array}{c}\text { Silt } \\
(p \mathrm{Ci} / \mathrm{kg})\end{array}$ & $\begin{array}{c}\text { Clay } \\
(\mathrm{pCi} / \mathrm{kg}) \\
\end{array}$ \\
\hline 26 & 8 & 97.2 & 0.7 & 2.1 & $4.57 \times 10^{2}$ & $2.29 \times 10^{3}$ & $4.57 \times 10^{3}$ \\
\hline & 9 & 100.0 & 0.0 & 0.0 & $1.11 \times 10^{3}$ & 0.0 & 0.0 \\
\hline & 10 & 100.0 & 0.0 & 0.0 & $1.05 \times 10^{3}$ & 0.0 & 0.0 \\
\hline 27 & 8 & 96.7 & 0.8 & 2.5 & $4.57 \times 10^{2}$ & $2.29 \times 10^{3}$ & $4.57 \times 10^{3}$ \\
\hline 28 & 8 & 97.1 & 0.7 & 2.2 & $4.63 \times 10^{2}$ & $2.29 \times 10^{3}$ & $4.57 \times 10^{3}$ \\
\hline 29 & 8 & 97.2 & 0.7 & 2.1 & $4.61 \times 10^{2}$ & $2.29 \times 10^{3}$ & $4.57 \times 10^{3}$ \\
\hline & 9 & 100.0 & 0.0 & 0.0 & $9.58 \times 10^{2}$ & 0.0 & 0.0 \\
\hline 30 & 8 & 93.2 & 1.6 & 5.2 & $6.36 \times 10^{2}$ & $3.18 \times 10^{3}$ & $6.36 \times 10^{3}$ \\
\hline 31 & 7 & 28.2 & 16.9 & 54.9 & $1.41 \times 10^{-6}$ & $1.50 \times 10^{3}$ & $3.14 \times 10^{3}$ \\
\hline 32 & 6 & 80.3 & 4.7 & 15.0 & $1.49 \times 10^{-7}$ & $9.88 \times 10^{2}$ & $2.09 \times 10^{3}$ \\
\hline 33 & 8 & 94.4 & 1.3 & 4.3 & $6.00 \times 10^{2}$ & $3.18 \times 10^{3}$ & $6.36 \times 10^{3}$ \\
\hline 34 & 8 & 96.5 & 0.9 & 2.6 & $5.28 \times 10^{1}$ & $2.59 \times 10^{2}$ & $5.19 \times 10^{2}$ \\
\hline & 9 & 100.0 & 0.0 & 0.0 & $5.79 \times 10^{2}$ & 0.0 & 0.0 \\
\hline 35 & 8 & 96.5 & 0.9 & 2.6 & $5.21 \times 10^{1}$ & $2.59 \times 10^{2}$ & $5.19 \times 10^{2}$ \\
\hline & 9 & 100.0 & 0.0 & 0.0 & $5.78 \times 10^{2}$ & 0.0 & 0.0 \\
\hline 36 & 8 & 96.5 & 0.9 & 2.6 & $5.22 \times 10^{1}$ & $2.59 \times 10^{2}$ & $5.19 \times 10^{2}$ \\
\hline & 9 & 100.0 & 0.0 & 0.0 & $5.32 \times 10^{2}$ & 0.0 & 0.0 \\
\hline & 10 & 100.0 & 0.0 & 0.0 & $2.46 \times 10^{2}$ & 0.0 & 0.0 \\
\hline 37 & 8 & 96.5 & 0.9 & 2.6 & $5.21 \times 10^{1}$ & $2.59 \times 10^{2}$ & $5.19 \times 10^{2}$ \\
\hline & 9 & 100.0 & 0.0 & 0.0 & $5.28 \times 10^{2}$ & 0.0 & 0.0 \\
\hline 38 & 8 & 98.1 & 0.5 & 1.4 & $1.27 \times 10^{2}$ & $6.32 \times 10^{2}$ & $1.26 \times 10^{3}$ \\
\hline & 9 & 100.0 & 0.0 & 0.0 & $6.12 \times 10^{2}$ & 0.0 & 0.0 \\
\hline & 10 & 100.0 & 0.0 & 0.0 & $2.72 \times 10^{2}$ & 0.0 & 0.0 \\
\hline
\end{tabular}

(a) This originally consisted of eight layers with the eighth layer representing the top layer. Only the contaminated layers are presented.

The average containment bed concentration for ${ }^{239} \mathrm{Pu}$ (i.e., weighted according to the depth of the respective bed layer) in lower Los Alamos Canyon (channel sections 30 through 38 ) decreased by $5.4 \%$ from that of the initial conditions. Also within lower Los Alamos Canyon, the average contaminant bed concentration for ${ }^{239} \mathrm{Pu}$ in channel sections 34 through 38 increased by a factor of 3.7 from that of the initial conditions in ths area. The reason for the increase in the average contaminant concentration in channel sections 34 through 38 and a decrease in the average concentration in channel sections 30 
through 38 is that $78.3 \%$ of the contaminated sediment from channel sections 30 through 33 was resuspended with part of it being deposited in channel sections 34 through 38 and part of it moving downstrean towards the Rio cirande. In other words, $55 \%$ of the ${ }^{239} \mathrm{Pu}$ reaching node 34 originated from channel sections 30 through 33 in lower Los Alamos Canyon. In effect, a redistribution of the ${ }^{239} \mathrm{Pu}$ inventory in the bed occurred in lower Los Alamos Canyon during the 50-year flood event. The average 239 bed concentration in channel sections 34 through 38 after simulation $(307.9 \mathrm{pCi} / \mathrm{kg})$ is still $60.3 \%$ lower than the initial conditions assumed for channel sections 30 through $33(775.0 \mathrm{pCi} / \mathrm{kg})$. Overall, the ${ }^{239} \mathrm{Pu}$ inventory in lower Los Alamos Canyon increased by approximately 1.1 times for the 50-year flood event. The inventory of $239 \mathrm{Pu}$ in any one layer is restricted by the amount of contaminated sand which can be held by that layer. In other words, the ${ }^{239}$ Pu inventory for any one layer is a function of its particulate concentration and the depth of the bed layer (which was chosen as $30 \mathrm{~cm}$ ). Increasing the depth of the bed layer may increase the net inventory for that layer without altering the contaminant concentration.

After the 15-hour duration, the flood wave had pretty much passed through the system. Remaining was a small residual base flow which was imposed to improve the numerical stability of TUDAM. The net error in mass balance between the initial and final inventories of ${ }^{239} \mathrm{Pu}$ for the modeling scenario was $0.2 \%$.

Limitations

Every modeling scenario contains limitations. The major limitations of this study include:

(1) Under this study, only a possible 50-yr flood event was tested. Ideally, several flood events with larger return periods should be simulated. In addition, varying scenarios (e.g., varying crosssectional shapes) should be investigated to fully comprehend the effects various scenarios have on mechanisms governing the ${ }^{239} \mathrm{Pu}$ movement.

(2) Simulation results obtained in this study indicate what may happen for a 50-yr flood event under the given assumptions and conditions used for this study. 
(3) The movement of sand particles (diameter equally $0.76 \mathrm{~mm}$ for this study) was simulated by using Toffaleti's methodology. The sand sediment size of $0.76 \mathrm{~mm}$ is very close to the upper limit for which Toffaleti's sediment routing formulation is applicable. In the event larger-sized particles are to be simulated, the Schoklitsch or MeyerPeter-Muller (Vanoni 1975) algorithms could have been employed in the modeling scenario.

(4) The mechanism governing the deposition and resuspension of sediment in stream is a function of several factors. Some of these include bed slope, flow velocity, shear stress, cross-sectional shape, sediment characteristics, fluid characteristics, watershed characteristics, etc. This represents nighly complex phenomena not easily simulated accurately at this time. Some limitations innerent in the modeling itself include: a) The bed slope was not updated every time increment after the bed experienced aggradation or degradation. This affects the amount of sediment entrained or deposited from or to the bed. The changes, of course, may be insignificant. (b) The procedure employed in this simulation for computing possible armoring may have shortcomings. Since only one alluvial size (e.g., sand, gravel, etc.) is used in the sediment simulation algorithms, then the degree of armoring of the bed may be underestimated. By including larger alluvial-sized particles, the amount of sediment entrained from the bed may be less than that estimated in the simulation. This requires only a minor modification to TODAM. However, proper data was not available (e.g., core drillings) to calibrate the sediment sub-model based on Pueblo Canyon. Some information pertaining to nearby Mortandad Canyon was used, though.

(5) As mentioned in the text, several areas in the modeling scenario could have used more information (e.g., more cross-sectional information), if it were available. Data shortcomings are inherent, though, in any modeling scenario. It should be remembered that the simulation results are only as good as the data the numerical codes use. 
$\therefore$

$\because$

.. 


\subsection{REFERENCES}

Abrahams, J. H., J. E. Weir, Jr., W. D. Purtymun. 1961. "Distribution of Moisture in Soil and Near-Surface Tuff on the Pajarito Plateau, Los Alamos County, New Mexico." Short Papers in the Geologic and Hydrologic Sciences, Articles 293-435, Geological Survey Research.

Barnes, H. H. 1967. "Roughness Characteristics of Natural Channels." Geological Survey Water Supply Paper 1849, U.S. Government Printing Office, Washington, D.C.

Brandstetter, A. B. 1977. "Assessment of Mathematical Models for Storm andCombined Sewer Management," Report EPA-600/2-76-175a, U.S. Environmental Protection Agency, Cincinnati, Ohio.

Brown, J. W., et al. 1977. "Models and Methods Applicable to Corps of Engineers Urban Studies," MisC. Paper H-74-8, Waterways Experiment Station, U.S. Army Corps of Engineers, NTIS AD-786 516, Vicksburg, Mississippi.

Chow, V. T. 1959. Open-Channel Hydraulics, McGraw Hill, New York, New York.

Crawford, N. H., and A. S. Donigian, Jr. 1973. "Pesticide Transport and Runoff Model for Agricultural Lands." Office of Research and Development, U.S. Environmental Protection Agency, Washington, DC, EPA 660/2-74-013.

Cunge, J. A. 1969. "On the Subject of a Flood Propagation Computation Method (Muskingum Method)." J. Hydraulic Research 7(2):205-230.

Donigian, A. S., Jr., and N. H. Crawford. 1976a. "Modeling Pesticides and Nutrients on Agricultural Lands." EPA-600/2-76-043, U.S. Environmental Protection Agency, Athens, Georgia.

Donigian, A. S., Jr., and N. H. Crawford. 1976b. "Modeling Nonpoint Pollution from the Land Surface." EPA-600/3-76-083, U.S. Environmental Protection Agency, NTIS PB-250 566, Athens, Georgia.

Donigian, A. S., Jr., and H. H. Davis, Jr. 1978. "User's Manual for Agricultural Runoff Management (ARM) Mode1." EPA-600/3-78-080, U.S. Environmental Protection Agency, Athens, Georgia.

Donigian, A. S., Jr., and N. H. Crawford. 1979. "User's Manual for the Nonpoint Source (NPS) Model." Office of Research and Development, U.S. Environmental Protection Agency.

Donigian, A. S., Jr., et al. 1977. "Agricultural Runoff Management (ARM) Model-Version II: Refinement and Testing." EPA-600/3-77-098, U.S. Environmental Protection Agency, Athens, Georgia. 
Environmental Service Group. 1978. Environmental Surveillance at Los Alamos During 1977. Report LA-7263-MS, LoS Alamos Scientific Laboratory, LoS Alamos, New Mexico.

Environmental Service Group. 1979. Environmental Surveillance at Los Alamos During 1978. Report LA-7800-ENV, LOS Alamos Scientific Laboratory, LoS Alamos, New Mexico.

Environmental Service Group. 1980. Environmental Surveillance at Los Alamos During 1979. Report LA-8200-ENV, LOS Alamos Scientific Laboratory, LoS Alamos, New Mexico.

Environmental Service Group. 1981. Environmental Surveillance at Los Al amos During 1980. Report LA-8810-ENV, LOS ATamos Scientific Laboratory, LoS

Alamos, New Mexico.

Fischer, H. B. 1967. "Mechanics of Dispersion in Natural Streams," J. Hydraul. Div. HYG, ASCE.

Graf, W. H. 1971. Hydraulics of Sediment Transport. McGraw-Hill, New York.

Hakonson, T. E., L. J. Johnson, and W. D. Purtymun. 1973. "The Distribution of Plutonium in Liquid Waste Disposal at Los Alamos." Third International Congress of the International Radiation Protection Association, Washington, D.C.

Hakonson, T. E., J. W. Nyhan, L. J. Johnson, and K. V. Bostick. 1973. "Ecological Investigation of Radioactive Materials in Waste Discharge Areas at Los Alamos," Los Alamos Scientific Laboratory Report LA-5282-MS.

Hakonson, T. E., J. W. Nyhan, and W. D. Purtymun. 1975. "Accumulation and Transport of Soil Plutonium in Liquid Waste Discharge Areas at Los Alamos." IAEA Symposium on Transuranics in the Environment, IAEA-SM-199/99.

Hydrocomp, Inc. 1976. "Hydrocomp Simulation Programming and Operations Manual," 4th ed., Palo Alto, California.

Hydrocomp, Inc. 1977. "Hydrocomp Water Quality Operations Manual," Palo Alto, California.

Johanson, R. C., J. C. Imoff, and H. H. Davis, Jr. 1980. User's Manual for Hydrological Simulation Program - Fortran (HSPF). EPA-600/9-80-015, U.S. Environmental Protection Agency, Athens, Georgia.

LANL. 1981. "Formerly Utilized MED/AEC Sites Remedial Action Program (FUSRAP)." W-7405-ENG-36, Los Alamos National Laboratory, Los Alamos, New Mexico. 
Nyhan, J. W., F. R. Miera, Jr., and R. J. Peters. 1976. "Distribution of Plutonium in Soil Particle Size Fractions of Liquid Effluent-Receiving Areas at Los Alamos," J. Environ. Qual.

01 sen, A. R., and S. E. Wise. 1979. "Frequency Analysis of Pesticide Concentrations for Risk Assessment, U.S. EPA Contract 2311103242 , Battelle, Pacific Northwest Laboratories, Richland, Washington.

Onishi, Y. 1977. Mathematical Simulation of Sediment and Radionuclide Transport in the Columbia River. BNWL-2228, Pacific Northwest Laboratory, Richland, WA.

Onishi, Y., S. M. Brown, A. R. 01 sen, M. A. Parkhurst, S. E. Wise and W. H. Walters. 1979. Methodology for Overland and Instream Migration and Risk Assessment of Pesticides. Battelle, Pacific Northwest Laboratories, Richland, Washington, for the U.S. Environmental Protection Agency, 6A.

Onishi, Y., P. A. Johanson, R. G. Baca and E. L. Hilty. 1976. Studies of Columbia River Water Quality--Development of Mathematical Models of Sediment and Radionuclide Transport Analysis. BNWL-B-452, Battelle, Pacific Northwest Laboratories, Richland, Washington.

Onishi, Y., and S. E. Wise. 1979. "Mathematical Model, SERATA, for SedimentContaminant Transport in Rivers and Its Application to Pesticide Transport in Four Mile and Wolf Creeks in Iowa." Submitted to U.S. Environmental Protection Agency, Environmental Research Laboratory at Athens, GA by Battelle, Pacific Northwest Laboratories, Richland, Washington.

Onishi, Y., R. J. Serne, E. M. Arnold, C. E. Cowan, and F. L. Thompson. 1981. Critical Review: Radionuclide Transport, Sediment Transport and Water Qual ity Mathematical Modeling, and Radionuclide Adsorption/Desorption Mechanisms. NUREG/CR-1322, PNL-2901, Pacific Northwest Laboratory, Richland, WA.

Onishi, Y., G. Whelan, and R. L. Skaggs. 1982. Development of a Multimedia Radionuclide Exposure Model for Low-Level Waste Management. PNL-3370, Pacific Northwest Laboratory, Richland, Washington.

Overcash, M. R., and J. M. Davidson. 1980. Environmental Impact of Nonpoint Source Pollution. Ann Arbor Science, Ann Arbor, Michigan.

Parkhurst, M. A., G. Whelan, Y. Onishi, and A. R. 01 sen. 1981. Simulation of the Migration, Fate, and Effects of Diazinon in Two Monticello Stream Channels, Battelle, Pacific Northwest Laboratories, Richland, Washington.

Ponce, V. M., and V. Yevjevich. 1978. "Muskingum-Cunge Method with Variable Parameters." J. Hydraulics Div., ASCE 104(12):1663-1667.

Purtymun, W. D. 1974a. "Dispersion and Movement of Tritium in a Shallow Aquifer in Mortandad Canyon at the Los Alamos Scientific Laboratory." LA-5716-MS. Los Alamos Scientific Laboratory, Los Alamos, New Mexico. 
Purtymun, W. D. 1974b. "Storm Runoff and Transport of Radionuclides in DP Canyon, Los Alamos County, New Mexico." Los Alamos Scientific Laboratory Report LA-5744.

Purtymun, W. D., G. L. Johnson, E. C. John. 1966. "Distribution of Radioactivity in the Alluvium of a Disposal Area at Los Alamos, New Mexico." U.S. Geol. Survey Prof. Paper 550-D:D250-D252.

Scott, A. G. 1971. "Preliminary Flood-Frequency Relations and Summary of Maximum Discharges in New Mexico--A Progress Report." U.S. Geological Survey Open-File Report, 76 pp., 8 figs.

Scott, A. G. 1974. "Project Evaluation of 'Investigation and Analysis of Floods from Small Drainage Areas in New Mexico'--A Progress Report." U.S. Geological Survey Open-File Report, Albuquerque, New Mexico.

Scott, A. G., and J. L. Kunkler. 1976. "Flood Discharges of Streams in New Mexico as Related to Channel Geometry." U.S. Geological Survey Open-File Report 76-414, 30 pp., 6 figs.

Toffaleti, F. B. 1968. "A Procedure for Computation of the Total River Sand Discharge and Detailed Distribution, Bed to Surface." Technical Report No. 5, Committee on Channel Stabilization, Corps of Engineers, U.S. Army.

Vanoni, V. A. (ed). 1975. Sedimentation Engineering. ASCE MR No. 54. American Society of Civil Engineers, New York, New York.

Wheeler, M. L. 1979. "Hydro-Geologic Setting." Los Alamos Scientific Laboratory, Los Alamos, New Mexico.

Whelan, G. 1980. Distributed Model for Sediment Yield, Master's Thesis, Mechanics and Hydraulics, University of Iowa, Iowa City, Iowa.

Whelan, G. 1982. Chapter 3 of "Multimedia Environmental Assessment Methodology for Coal-Fired Power Plants--Quarterly Progress Report." Prepared for Rand Corporation, Santa Monica, California, Under Contract 23112-4849. Battelle, Pacific Northwest Laboratories, Richland, Washington. 
APPENDIX A

CROSS-SECTIONAL INFORMATION 


$\begin{array}{cccc}\begin{array}{c}\text { Section } \\ 1\end{array} & \text { No. } & \text { Elevation } & \text { Width } \\ & & & \\ 1 & 0.00 E+00 & 0.00 E+00 \\ 2 & 3.00 E-03 & 4.89 E+00 \\ 3 & 2.10 E-10 & 5.82 E+00 \\ 4 & 4.02 E-01 & 6.59 E+00 \\ 5 & 7.65 E-01 & 7.86 E+00 \\ 6 & 8.29 E-01 & 8.02 E+00 \\ 7 & 1.13 E+00 & 8.78 E+00 \\ 8 & 3.39 E+00 & 1.45 E+01\end{array}$

Section

2

$\begin{array}{llll}\text { No. } & \text { Elevation } & & \text { Width } \\ 1 & 0.00 E+00 & & 0.00 E+00 \\ 2 & 3.00 E-03 & 4.89 E+00 \\ 3 & 2.10 E-01 & 5.82 E+00 \\ 4 & 4.02 E-01 & 6.59 E+00 \\ 5 & 7.65 E-01 & 7.86 E+00 \\ 6 & 8.29 E-01 & 8.02 E+00 \\ 7 & 1.13 E+00 & 8.78 E+00 \\ 8 & 3.39 E+00 & 1.45 E+01\end{array}$

Section

3

No.

Elevation

Width

1

$0.00 E+00$

$0.00 E+00$

3. $00 \mathrm{E}-03$

$4.89 E+00$

2.10E-01

$5.82 E+00$

4. $02 \mathrm{E}-01$

$6.59 \mathrm{E}+00$

7. $65 \mathrm{E}-01$

$7.86 \mathrm{E}+00$

8.29E-01

$8.02 E+00$

$1.13 E+00$

$8.78 \mathrm{E}+00$

$3.39 E+00$

$1.45 E+01$

Section

4

No.
1
2
3
4
5
6
7
8

Elevation

Width

$0.00 E+00$

$0.00 \mathrm{E}+00$

3. $00 \mathrm{E}-03$

$4.89 E+00$

2. 10E-01

$5.82 E+00$

4. $02 \mathrm{E}-01$

$6.59 E+00$

7.65E-01

$7.86 \mathrm{E}+00$

8.29E-01

$8.02 E+00$

$1.13 E+00$

$8.78 \mathrm{E}+00$

3. $39 E+00$

$1.45 E+01$ 


$\begin{array}{cccc}\begin{array}{c}\text { Section } \\ 5\end{array} & \text { No. } & \text { Elevation } & \text { Width } \\ & 1 & 0.00 E+00 & \\ & 3 & 3.00 E-03 & 4.00 E+00 \\ 3 & 2.10 E-01 & 5.82 E+00 \\ 4 & 4.02 E-01 & 6.59 E+00 \\ 5 & 7.65 E-01 & 7.86 E+00 \\ 6 & 8.29 E-01 & 8.02 E+00 \\ 7 & 1.13 E+00 & 8.78 E+00 \\ 8 & 3.39 E+00 & 1.45 E+01\end{array}$

Section

$\frac{6}{6} \quad$ No.

$\begin{array}{llll}\text { No. } & \text { Elevation } & & \text { Width } \\ 1 & & & \\ 2 & 0.00 E+00 & & 0.00 E+00 \\ 3 & 3.00 E-03 & & 4.89 E+00 \\ 4 & 2.10 E-01 & & 5.82 E+00 \\ 5 & 4.02 E-01 & 6.59 E+00 \\ 6 & 7.65 E-01 & 7.86 E+00 \\ 7 & 8.29 E-01 & 8.02 E+00 \\ 8 & 1.13 E+00 & 8.78 E+00 \\ & 3.39 E+00 & 1.45 E+01\end{array}$

Section

7

No.
1
2
3
4
5
6
7
8

Elevation

Width

$0.00 E+00$

$0.00 E+00$

3. $00 \mathrm{E}-03$

$4.89 E+00$

2. $10 E-01$

4.02E-01

7.65E-01

8.29E-01

$1.13 E+00$

$3.39 E+00$

$5.82 E+00$

$6.59 E+00$

$7.86 E+00$

$3.02 E+00$

$8.78 \mathrm{E}+00$

$1.45 E+01$

Section

8

\begin{tabular}{l} 
No. \\
\hline 1 \\
2 \\
3 \\
4 \\
5 \\
6 \\
7 \\
8
\end{tabular}

Elevation

Width

$0.00 E+00$

3. $00 E-03$

2. 10E-01

4.02E-01

7.65E-01

8.29E-01

$1.13 \mathrm{E}+00$

$3.39 E+00$

$0.00 E+00$

$4.89 E+00$

$5.82 E+00$

$6.59 E+00$

$7.86 \mathrm{E}+00$

$8.02 E+00$

$8.78 E+00$

$1.45 E+01$ 


\begin{tabular}{|c|c|c|c|}
\hline $\begin{array}{c}\text { Section } \\
9 \\
\end{array}$ & No. & Elevation & Width \\
\hline & $\begin{array}{l}1 \\
2 \\
3 \\
4 \\
5 \\
6 \\
7 \\
8\end{array}$ & $\begin{array}{l}0.00 E+00 \\
3.00 E-03 \\
2.10 E-01 \\
4.02 E-01 \\
7.65 E-01 \\
8.29 E-01 \\
1.13 E+00 \\
3.39 E+00\end{array}$ & $\begin{array}{l}0.00 \mathrm{E}+00 \\
4.89 \mathrm{E}+00 \\
5.82 \mathrm{E}+00 \\
6.59 \mathrm{E}+00 \\
7.86 \mathrm{E}+00 \\
8.02 \mathrm{E}+00 \\
8.78 \mathrm{E}+00 \\
1.45 \mathrm{E}+01\end{array}$ \\
\hline \multirow[t]{2}{*}{$\begin{array}{c}\text { Section } \\
10 \\
\end{array}$} & No. & Elevation & Width \\
\hline & $\begin{array}{l}1 \\
2 \\
3 \\
4 \\
5 \\
6 \\
7 \\
8\end{array}$ & $\begin{array}{l}0.00 E+00 \\
3.00 E-03 \\
2.10 E-01 \\
4.02 E-01 \\
7.65 E-01 \\
8.29 E-01 \\
1.13 E+00 \\
3.39 E+00\end{array}$ & $\begin{array}{l}0.00 \mathrm{E}+00 \\
4.89 \mathrm{E}+00 \\
5.82 \mathrm{E}+00 \\
6.59 \mathrm{E}+00 \\
7.86 \mathrm{E}+00 \\
8.02 \mathrm{E}+00 \\
8.78 \mathrm{E}+00 \\
1.45 \mathrm{E}+01\end{array}$ \\
\hline \multirow[t]{2}{*}{$\begin{array}{c}\text { Section } \\
11 \\
\end{array}$} & №. & Elevation & Width \\
\hline & $\begin{array}{l}1 \\
2 \\
3 \\
4 \\
5 \\
6 \\
7 \\
8 \\
9\end{array}$ & $\begin{array}{l}0.00 E+00 \\
1.22 E-01 \\
1.52 E-01 \\
1.89 E-01 \\
4.72 E-01 \\
9.75 E-01 \\
9.78 E-01 \\
1.10 E+00 \\
3.30 E+00\end{array}$ & $\begin{array}{l}0.00 E+00 \\
2.62 E+00 \\
3.01 E+00 \\
4.17 E+00 \\
4.93 E+00 \\
5.86 E+00 \\
5.89 E+00 \\
7.27 E+00 \\
3.22 E+01\end{array}$ \\
\hline \multirow[t]{2}{*}{$\begin{array}{c}\text { Sect } i \text { ion } \\
12 \\
\end{array}$} & No. & Elevation & Width \\
\hline & $\begin{array}{l}1 \\
2 \\
3 \\
4 \\
5 \\
6 \\
7 \\
8 \\
9\end{array}$ & $\begin{array}{l}0.00 E+00 \\
1.22 E-01 \\
1.52 E-01 \\
1.89 E-01 \\
4.72 E-01 \\
9.75 E-01 \\
9.78 E-01 \\
1.10 E+00 \\
3.30 E+00\end{array}$ & $\begin{array}{l}0.00 E+00 \\
2.62 E+00 \\
3.01 E+00 \\
4.17 E+00 \\
4.93 E+00 \\
5.86 E+00 \\
5.89 E+00 \\
7.27 E+00 \\
3.22 E+01\end{array}$ \\
\hline
\end{tabular}


Section

13

\begin{tabular}{c} 
No. \\
\hline 1 \\
2 \\
3 \\
4 \\
5 \\
6 \\
7 \\
8 \\
9
\end{tabular}

\begin{tabular}{l} 
Elevation \\
\hline $0.00 E+00$ \\
$1.22 E-01$ \\
$1.52 E-01$ \\
$1.89 E-01$ \\
$4.72 E-01$ \\
$9.75 E-01$ \\
$9.78 E-01$ \\
$1.10 E+00$ \\
$3.30 E+00$
\end{tabular}

Width

$0.00 E+00$

2. $62 E+00$

$3.01 E+00$

$4.17 E+00$

$4.93 E+00$

$5.86 E+00$

$5.89 E+00$

$7.27 E+00$

$3.22 E+01$

Section

14

$\begin{array}{cccc}\text { No. } & \text { Elevation } & & \text { Width } \\ 1 & & & 0.00 E+00 \\ 2 & 1.22 E-01 & & 2.62 E+00 \\ 3 & 1.52 E-01 & 3.01 E+00 \\ 4 & 1.89 E-01 & 4.17 E+00 \\ 5 & 4.72 E-01 & 4.93 E+00 \\ 6 & 9.75 E-01 & 5.86 E+00 \\ 7 & 9.78 E-01 & 5.89 E+00 \\ 8 & 1.10 E+00 & 7.27 E+00 \\ 9 & 3.30 E+00 & 3.22 E+01\end{array}$

Section

15

No.
1
2
3
4
5
6
7
8
9

Elevation

Width

$0.00 E+00$

1. $22 \mathrm{E}-01$

1. $52 \mathrm{E}-01$

$1.89 \mathrm{E}-01$

4.72E-01

$9.75 \mathrm{E}-01$

$9.78 \mathrm{E}-01$

$1.10 E+00$

3. $30 E+00$

$0.00 E+00$

2. $62 E+00$

$3.01 E+00$

4. $17 \mathrm{E}+00$

$4.93 E+00$

$5.86 E+00$

$5.89 \mathrm{E}+00$

$7.27 E+00$

$3.22 \mathrm{E}+01$

Section

16

\begin{tabular}{c} 
NNo. \\
\hline 1 \\
2 \\
3 \\
4 \\
5 \\
6 \\
7 \\
8 \\
9
\end{tabular}

Elevation

Width

$0.00 E+00$

$0.00 E+00$

1. $22 \mathrm{E}-01$

$1.52 \mathrm{E}-01$

$2.62 E+00$

$1.89 \mathrm{E}-01$

$3.01 E+00$

4.72E-01

4. $17 E+00$

$9.75 \mathrm{E}-01$

4. $93 \mathrm{E}+00$

$9.78 E-01$

$5.86 \mathrm{E}+01$

$1.10 E+00$

$5.89 E+00$

$7.27 \mathrm{E}+00$

3. $30 E+00$

3. $22 E+01$ 


\begin{tabular}{|c|c|c|c|}
\hline $\begin{array}{c}\text { Section } \\
17 \\
\end{array}$ & No. & Elevation & Width \\
\hline & $\begin{array}{l}1 \\
2 \\
3 \\
4\end{array}$ & $\begin{array}{l}0.00 E+00 \\
3.80 E-01 \\
1.91 E+00 \\
3.43 E+00\end{array}$ & $\begin{array}{l}0.00 E+00 \\
1.60 E+01 \\
3.73 E+01 \\
1.22 E+02\end{array}$ \\
\hline \multirow[t]{2}{*}{$\begin{array}{c}\text { Section } \\
18 \\
\end{array}$} & No. & Elevation & Width \\
\hline & $\begin{array}{l}1 \\
2 \\
3 \\
4 \\
5\end{array}$ & $\begin{array}{l}0.00 E+00 \\
7.62 E-01 \\
2.29 E+00 \\
3.81 E+00 \\
5.33 E+00\end{array}$ & $\begin{array}{l}0.00 E+00 \\
1.52 E+01 \\
9.14 E+01 \\
1.03 E+02 \\
1.56 E+02\end{array}$ \\
\hline \multirow[t]{2}{*}{$\begin{array}{c}\text { Section } \\
19 \\
\end{array}$} & №. & Elevation & Width \\
\hline & $\begin{array}{l}1 \\
2 \\
3 \\
4\end{array}$ & $\begin{array}{l}0.00 E+00 \\
1.52 E+00 \\
3.05 E+00 \\
3.57 E+00\end{array}$ & $\begin{array}{l}0.00 E+00 \\
3.81 E+01 \\
4.88 E+01 \\
1.37 E+02\end{array}$ \\
\hline \multirow[t]{2}{*}{$\begin{array}{c}\text { Section } \\
20 \\
\end{array}$} & №. & Elevation & Width \\
\hline & $\begin{array}{l}1 \\
2 \\
3 \\
4\end{array}$ & $\begin{array}{l}0.00 E+00 \\
6.40 E-01 \\
2.16 E+00 \\
3.69 E+00\end{array}$ & $\begin{array}{l}0.00 E+00 \\
1.52 E+01 \\
4.95 E+01 \\
1.14 E+02\end{array}$ \\
\hline \multirow[t]{2}{*}{$\begin{array}{c}\text { Section } \\
21 \\
\end{array}$} & No. & El evation & Width \\
\hline & $\begin{array}{l}1 \\
2 \\
3 \\
4\end{array}$ & $\begin{array}{l}0.00 E+00 \\
5.80 E-01 \\
2.10 E+00 \\
3.63 E+00\end{array}$ & $\begin{array}{l}0.00 \mathrm{E}+00 \\
5.33 \mathrm{E}+01 \\
9.14 \mathrm{E}+01 \\
1.91 \mathrm{E}+02\end{array}$ \\
\hline $\begin{array}{c}\text { Section } \\
22\end{array}$ & No. & Elevation & Width \\
\hline & $\begin{array}{l}1 \\
2 \\
3\end{array}$ & $\begin{array}{l}0.00 E+00 \\
1.52 E+00 \\
3.05 E+00\end{array}$ & $\begin{array}{l}0.00 E+00 \\
8.38 E+01 \\
9.91 E+01\end{array}$ \\
\hline
\end{tabular}




\begin{tabular}{|c|c|c|c|}
\hline $\begin{array}{c}\text { Section } \\
23 \\
\end{array}$ & No. & Elevation & Width \\
\hline & $\begin{array}{l}1 \\
2 \\
3 \\
4\end{array}$ & $\begin{array}{l}0.00 E+00 \\
6.10 E-01 \\
2.13 E+00 \\
3.66 E+00\end{array}$ & $\begin{array}{l}0.00 E+00 \\
3.81 E+01 \\
1.18 E+02 \\
1.75 E+02\end{array}$ \\
\hline
\end{tabular}

Section

24

$\begin{array}{llll}\text { No. } & \text { Elevation } & & \text { Width } \\ 1 & 0.00 \mathrm{E}+00 & & 0.00 \mathrm{E}+00 \\ 2 & 7.60 \mathrm{E}-01 & & 3.05 \mathrm{E}+01 \\ 3 & 2.29 \mathrm{E}+00 & & 1.37 \mathrm{E}+02 \\ 4 & 3.81 \mathrm{E}+00 & & 1.60 \mathrm{E}+02\end{array}$

Section

25

$\begin{array}{llll}\text { No. } & \text { Elevation } & & \text { width } \\ 1 & 0.00 E+00 & & 0.00 E+00 \\ 2 & 1.52 E+00 & & 6.86 E+01 \\ 3 & 3.05 E+00 & & 2.59 E+02\end{array}$

Section

26

\begin{tabular}{c} 
№. \\
\hline 1 \\
2 \\
3 \\
4 \\
5 \\
6 \\
7 \\
8 \\
9
\end{tabular}

Elevation

Width

$0.00 E+00$

$6.40 E-02$

$6.70 \mathrm{E}-02$

1. $71 \mathrm{E}-01$

2. 16E-01

2. $53 \mathrm{E}-01$

2. $68 \mathrm{E}-01$

$3.02 E-01$

3. $32 E+00$

$0.00 E+00$

$2.27 E+00$

2. $35 E+00$

$2.92 E+00$

$3.07 \mathrm{E}+00$

$4.83 \mathrm{E}+00$

$6.68 \mathrm{E}+00$

$7.98 \mathrm{E}+00$

1. $00 \mathrm{E}+02$

Section

27

\begin{tabular}{|c|c|c|}
\hline №. & Elevation & Width \\
\hline 1 & $0.00 E+00$ & $0.00 E+00$ \\
\hline 2 & $6.40 E-02$ & $2.27 E+00$ \\
\hline 3 & $6.70 E-02$ & $2.35 E+00$ \\
\hline 4 & $1.71 E-01$ & $2.92 E+00$ \\
\hline 5 & $2.16 E-01$ & $3.07 \mathrm{E}+00$ \\
\hline 6 & $2.53 E-01$ & $4.83 E+00$ \\
\hline 7 & $2.68 E-01$ & $6.68 E+00$ \\
\hline 8 & $3.02 E-01$ & $7.98 \mathrm{E}+00$ \\
\hline 9 & $3.32 E+00$ & $1.00 E+02$ \\
\hline
\end{tabular}




\begin{tabular}{|c|c|c|c|}
\hline $\begin{array}{c}\text { Section } \\
28 \\
\end{array}$ & No. & Elevation & Width \\
\hline & $\begin{array}{l}1 \\
2 \\
3 \\
4\end{array}$ & $\begin{array}{l}0.00 E+00 \\
7.62 E-01 \\
1.52 E+00 \\
4.56 E+00\end{array}$ & $\begin{array}{l}0.00 E+00 \\
3.96 E+01 \\
7.93 E+01 \\
2.39 E+02\end{array}$ \\
\hline \multirow[t]{2}{*}{$\begin{array}{c}\text { Section } \\
29 \\
\end{array}$} & No. & Elevation & Width \\
\hline & $\begin{array}{l}1 \\
2 \\
3 \\
4\end{array}$ & $\begin{array}{l}0.00 E+00 \\
7.62 E-01 \\
1.52 E+00 \\
4.56 E+00\end{array}$ & $\begin{array}{l}0.00 E+00 \\
2.13 E+01 \\
4.27 E+01 \\
2.39 E+02\end{array}$ \\
\hline \multirow[t]{2}{*}{$\begin{array}{c}\text { Section } \\
30 \\
\end{array}$} & No. & Elevation & Width \\
\hline & $\begin{array}{l}1 \\
2 \\
3 \\
4\end{array}$ & $\begin{array}{l}0.00 E+00 \\
7.62 E-01 \\
1.52 E+00 \\
4.56 E+00\end{array}$ & $\begin{array}{l}0.00 E+00 \\
2.13 E+01 \\
4.27 E+01 \\
2.39 E+02\end{array}$ \\
\hline \multirow[t]{2}{*}{$\begin{array}{c}\text { Section } \\
31 \\
\end{array}$} & No. & Elevation & Width \\
\hline & $\begin{array}{l}1 \\
2 \\
3 \\
4 \\
5 \\
6\end{array}$ & $\begin{array}{l}0.00 E+00 \\
3.00 E-02 \\
1.30 E-01 \\
2.40 E-01 \\
3.00 E-01 \\
4.50 E+00\end{array}$ & $\begin{array}{l}0.00 E+00 \\
1.94 E+00 \\
2.36 E+00 \\
3.60 E+00 \\
4.09 E+00 \\
3.84 E+01\end{array}$ \\
\hline \multirow[t]{2}{*}{$\begin{array}{c}\text { Section } \\
32 \\
\end{array}$} & No. & Elevation & Width \\
\hline & $\begin{array}{l}1 \\
2 \\
3 \\
4 \\
5 \\
6\end{array}$ & $\begin{array}{l}0.00 \mathrm{E}+00 \\
3.00 \mathrm{E}-02 \\
1.30 \mathrm{E}-01 \\
2.40 \mathrm{E}-01 \\
3.00 \mathrm{E}-01 \\
4.50 \mathrm{E}+00\end{array}$ & $\begin{array}{l}0.00 E+00 \\
1.94 E+00 \\
2.36 E+00 \\
3.60 E+00 \\
4.09 E+00 \\
3.84 E+01\end{array}$ \\
\hline
\end{tabular}


Section
33

$\begin{array}{llll}\text { No. } & \text { Elevation } & & \text { Width } \\ 1 & 0.00 E+00 & & 0.00 E+00 \\ 2 & 3.00 E-02 & & 1.94 E+00 \\ 3 & 1.30 E-01 & 2.36 E+00 \\ 4 & 2.40 E-01 & 3.60 E+00 \\ 5 & 3.00 E-01 & 4.09 E+00 \\ 6 & 4.50 E+00 & 3.84 E+01\end{array}$

Section

34

No.
1
2
3
4
5
6

Elevation

Width

$0.00 E+00$

3. $00 E-02$

1. 30E-01

2. $40 E-01$

3. $00 E-01$

4. $50 E+00$

$0.00 E+00$

1. $94 \mathrm{E}+00$

2. $36 E+00$

3. $60 \mathrm{E}+00$

$4.09 E+00$

$3.84 \mathrm{E}+01$

Section

35

\begin{tabular}{|c|c|c|}
\hline No. & Elevation & Width \\
\hline 1 & $0.00 E+00$ & $0.00 E+00$ \\
\hline 2 & $9.14 E-03$ & $1.35 E+00$ \\
\hline 3 & $5.79 E-02$ & $3.19 E+00$ \\
\hline 4 & $1.01 E-01$ & $4.44 E+00$ \\
\hline 5 & $1.16 E-01$ & $4.82 E+00$ \\
\hline 6 & $2.10 E-01$ & $6.23 E+00$ \\
\hline 7 & $4.11 E-01$ & $7.75 E+00$ \\
\hline 8 & $4.18 E-01$ & $7.80 E+00$ \\
\hline 9 & $5.73 E-01$ & $9.27 E+00$ \\
\hline 10 & $3.44 E+00$ & $3.64 E+01$ \\
\hline
\end{tabular}

Section

36

№.
1
2
3
4
5
6
7
8
9
10

Elevation

Width

$0.00 E+00$

$0.00 E+00$

1. $35 \mathrm{E}+00$

$9.14 \mathrm{E}-03$

$3.19 E+00$

$5.79 \mathrm{E}-02$

4. $44 E+00$

$1.16 \mathrm{E}-01$

$4.82 E+00$

2. $10 E-01$

$6.23 E+00$

$4.11 E-01$

$7.75 E+00$

$4.18 E-01$

$7.80 E+00$

$5.73 E-01$

$9.27 E+00$

$3.64 E+01$ 


\begin{tabular}{|c|c|c|c|}
\hline $\begin{array}{c}\text { Section } \\
37\end{array}$ & No. & Elevation & Width \\
\hline & $\begin{array}{r}1 \\
2 \\
3 \\
4 \\
5 \\
6 \\
7 \\
8 \\
9 \\
10\end{array}$ & $\begin{array}{l}0.00 \mathrm{E}+00 \\
9.14 \mathrm{E}-03 \\
5.79 \mathrm{E}-02 \\
1.01 \mathrm{E}-01 \\
1.16 \mathrm{E}-01 \\
2.10 \mathrm{E}-01 \\
4.11 \mathrm{E}-01 \\
4.18 \mathrm{E}-01 \\
5.73 \mathrm{E}-01 \\
3.44 \mathrm{E}+00\end{array}$ & $\begin{array}{l}0.00 \mathrm{E}+00 \\
1.35 \mathrm{E}+00 \\
3.19 \mathrm{E}+00 \\
4.44 \mathrm{E}+00 \\
4.82 \mathrm{E}+00 \\
6.23 \mathrm{E}+00 \\
7.75 \mathrm{E}+00 \\
7.80 \mathrm{E}+00 \\
9.27 \mathrm{E}+00 \\
3.64 \mathrm{E}+01\end{array}$ \\
\hline \multirow[t]{2}{*}{$\begin{array}{c}\text { Section } \\
\quad 38 \\
\end{array}$} & №. & Elevation & Width \\
\hline & $\begin{array}{r}1 \\
2 \\
3 \\
4 \\
5 \\
6 \\
7 \\
8 \\
9 \\
10\end{array}$ & $\begin{array}{l}0.00 \mathrm{E}+00 \\
9.14 \mathrm{E}-03 \\
5.79 \mathrm{E}-02 \\
1.01 \mathrm{E}-01 \\
1.16 \mathrm{E}-01 \\
2.10 \mathrm{E}-01 \\
4.11 \mathrm{E}-01 \\
4.18 \mathrm{E}-01 \\
5.73 \mathrm{E}-01 \\
3.44 \mathrm{E}+00\end{array}$ & $\begin{array}{l}0.00 \mathrm{E}+00 \\
1.35 \mathrm{E}+00 \\
3.19 \mathrm{E}+00 \\
4.44 \mathrm{E}+00 \\
4.82 \mathrm{E}+00 \\
6.23 \mathrm{E}+00 \\
7.75 \mathrm{E}+00 \\
7.80 \mathrm{E}+00 \\
9.27 \mathrm{E}+00 \\
3.64 \mathrm{E}+01\end{array}$ \\
\hline \multirow[t]{2}{*}{$\begin{array}{c}\text { Section } \\
39 \\
\end{array}$} & No. & Elevation & Width \\
\hline & $\begin{array}{r}1 \\
2 \\
3 \\
4 \\
5 \\
6 \\
7 \\
8 \\
9 \\
10\end{array}$ & $\begin{array}{l}0.00 \mathrm{E}+00 \\
9.14 \mathrm{E}-03 \\
5.79 \mathrm{E}-02 \\
1.01 \mathrm{E}-01 \\
1.16 \mathrm{E}-01 \\
2.10 \mathrm{E}-01 \\
4.11 \mathrm{E}-01 \\
4.18 \mathrm{E}-01 \\
5.73 \mathrm{E}-01 \\
3.44 \mathrm{E}+00\end{array}$ & $\begin{array}{l}0.00 \mathrm{E}+00 \\
1.35 \mathrm{E}+00 \\
3.19 \mathrm{E}+00 \\
4.44 \mathrm{E}+00 \\
4.82 \mathrm{E}+00 \\
6.23 \mathrm{E}+00 \\
7.75 \mathrm{E}+00 \\
7.80 \mathrm{E}+00 \\
9.27 \mathrm{E}+00 \\
3.64 \mathrm{E}+01\end{array}$ \\
\hline
\end{tabular}




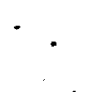

i 
DISTR IBUTION

No. of

Copies

OFFSITE

27 DOE Technical Information Center

R. A. Baker

U.S. Geological Survey

National Space Technology Laboratories

NSTL Station, MS 39529

$K$. Bencala

U.S. Geological Survey

MS/ 96

345 Middlefield Rd.

Men To Park, CA 94025

R. B. Code 11

U.S. Nuc lear Regulatory Commission

Washington, DC 20555

J. J. Davis

Office of Nuclear Regulatory Research

U.S. Nuclear Regulatory Commiss ion

Washington, DC 20555

L. A. Mulkey

U.S. Environmental Protection Agency

Environmental Research Laboratory

Athens, GA 30603

P. R. Reed

Office of Nuc lear Regulatory Research

U.S. Nuclear Regulatory Commission

Washington, DC 20555
No. of

Copies

P. F. Ricci

Electric Power Research

Institute

P.0. Box 10412

Palo Alto, CA 94303

5 J. C. Rodgers

Mai 1 Stop 495

Los Alamos National Laboratory

P.0. Box 1663

Los Alamos, NM 87545

G. Set lock

Rockwell International

Rocky Flast

P.0. Box 464

Golden, CO 80401

R. D. Smith

Office of Nuclear Material

Safety and Safeguard

U.S. Nuclear Regulatory

Commiss ion

Washington, DC 20555

J. W. Falco

U.S. Environmental Protection Agency

Off ice of Research and

Development

401 M. St. SW

Washington, DC 20460

W. Hanson

Mail Stop 495

Los Alamos National Laboratory

P.0. Box 1663

Los Alamos, NM 87545 
No. of

Copies

F. 0. Hoffman

Health and Safety Research

Division

Oak Ridge National Laboratory

P.0. Box $X$

Oak Ridge, TN 37830

J. Steger

Health Division

Mail Stop 495

Los Alamos National Laboratory

P.0. Box 1663

Los Alamos, NM 87545

W. Wood

Office of Toxic Substances

U.S. Environmental Protection Agency

401 M. St. SW

Washington, DC 20460

G. T. Yeh

Environmental Science Division

Oak Ridge National

Laboratory

Oak Ridge, TN 37830

G. Werk

EMA

U.S. Department of Energy

Albuquerque Operations Office

P.0. Box 5400

Albuquerque, NM 87115
No. of

Copies

Battelle Memorial Institute

Office of Nuclear Waste

Isolation

Attn: Beverly Rawles

505 King Avenue

Columbus, $\mathrm{OH} 43201$

ONSITE

DOE Richland Operations Office

H. E. Ransom

15 Pacific Northwest Laboratory

Y. Onishi

S. B. Yabusaki

G. Whelan (5)

F. L. Thompson

Technical Information (5)

Publishing Coordination BE(2) 


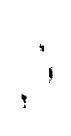

. 